\title{
Indonesia: 2016 Article IV Consultation-Press Release; Staff Report; and Statement by the Executive Director for Indonesia
}




\section{INTERNATIONAL MONETARY FUND}

\section{INDONESIA}

IMF Country Report No. 17/37

February 2017

\section{ARTICLE IV CONSULTATION-PRESS RELEASE; STAFF REPORT; AND STATEMENT BY THE EXECUTIVE DIRECTOR FOR INDONESIA}

Under Article IV of the IMF's Articles of Agreement, the IMF holds bilateral discussions with members, usually every year. In the context of the 2016 Article IV consultation with Indonesia, the following documents have been released and are included in this package:

- A Press Release summarizing the views of the Executive Board as expressed during its January 25, 2017 consideration of the staff report that concluded the Article IV consultation with Indonesia.

- The Staff Report prepared by a staff team of the IMF for the Executive Board's consideration on January 25, 2017, following discussions that ended on November 18, 2016, with the officials of Indonesia on economic developments and policies. Based on information available at the time of these discussions, the staff report was completed on December 27, 2016.

- An Informational Annex prepared by the IMF staff.

- A Staff Statement updating information on recent developments.

- A Statement by the Executive Director for Indonesia.

The documents listed below have been or will be separately released.

Selected Issues

The IMF's transparency policy allows for the deletion of market-sensitive information and premature disclosure of the authorities' policy intentions in published staff reports and other documents.

Copies of this report are available to the public from

International Monetary Fund • Publication Services

PO Box $92780 \bullet$ Washington, D.C. 20090

Telephone: (202) 623-7430 • Fax: (202) 623-7201

E-mail: publications@imf.org Web: http://www.imf.org

Price: $\$ 18.00$ per printed copy

\section{International Monetary Fund Washington, D.C.}

(C) 2017 International Monetary Fund

CInternational Monetary Fund. Not for Redistribution 
Press Release No. 17/36

FOR IMMEDIATE RELEASE

February 3, 2017
International Monetary Fund

$70019^{\text {th }}$ Street, NW

Washington, D. C. 20431 USA

\section{IMF Executive Board Concludes 2016 Article IV Consultation with Indonesia}

On January 25, 2017, the Executive Board of the International Monetary Fund (IMF) concluded the Article IV consultation ${ }^{1}$ with Indonesia.

Indonesia has maintained macroeconomic stability, while adjusting well to recent shifts in the external environment. A prudent mix of macroeconomic policies and the launch of structural reforms has helped the economy weather slow global growth, the commodity down-cycle, and several episodes of financial turbulence affecting emerging market economies. While growth has slowed slightly, it has remained robust. Inflation has eased and the external position has improved. A gradual fiscal consolidation has begun. There has been major progress on the financial stability framework, and gaps related to the crisis management framework are being addressed. Structural reforms that began in 2015 have improved the business environment. Positive sentiment has been reflected in supportive capital inflows in 2016, which buoyed financial markets before undergoing some corrections starting in October.

Private consumption remains the main driver of growth, but higher inclusive growth will require deeper structural reforms. Consumption growth has been underpinned by an expanding middle class, lower fuel prices, and falling inflation. Investment has remained subdued, reflecting spillovers from lower commodity prices, some excess capacity in mining and manufacturing, and structural impediments, while external demand has been weak. In staff's views, consumption-led growth can be sustained over the medium term, but meeting the authorities' ambitious targets for inclusive growth will require deepening structural reforms.

The near-term outlook remains favorable. Growth in 2016 is projected at 5 percent on account of robust private consumption. In 2017, growth is expected to rise modestly to 5.1 percent, led by a gradual pickup in private investment in response to stronger commodity prices, low interest

\footnotetext{
${ }^{1}$ Under Article IV of the IMF's Articles of Agreement, the IMF holds bilateral discussions with members, usually every year. A staff team visits the country, collects economic and financial information, and discusses with officials the country's economic developments and policies. On return to headquarters, the staff prepares a report, which forms the basis for discussion by the Executive Board.
} 
rates, and a recovery in external demand on the back of a pickup in global growth and trade. Inflation is expected to rise from 3.2 percent at end-2016 to around 4.5 percent at end-2017 largely due to lower electricity subsidies and some recovery in commodity prices. The current account deficit would remain at around 2 percent of GDP next year, with the expected pickup in fixed investment and imports offset by the impact of higher commodity prices on exports.

\section{Executive Board Assessment ${ }^{2}$}

Executive Directors commended the authorities for their successful management of macroeconomic policies and progress on structural reforms, which have preserved stability amidst challenging shifts in the external environment. Directors noted that, while the economy is subject to downside risks, the outlook is positive and Indonesia is better placed today to weather an uncertain external environment than in previous years. Against that background, they encouraged the authorities to continue strengthening the medium-term policy framework through fiscal and structural reforms to support inclusive growth and preserve macro stability.

Directors welcomed the authorities' fiscal strategy, which aims to broaden the revenue base and expand priority expenditures, while enhancing their efficiency within the statutory fiscal deficit limit. They supported the government's short-term fiscal stance, including the start of a gradual fiscal consolidation in August 2016 focused on rebuilding fiscal buffers. Directors saw merit in tax reform measures to generate the bulk of additional revenues needed to increase spending on infrastructure, health and education, which is low compared to peer emerging market economies. They supported the authorities' plans to pursue growth-friendly tax reforms this year, including administration reforms that would lower taxpayers' compliance costs.

Directors considered that the current monetary policy stance is broadly appropriate and encouraged the authorities to remain vigilant to the resurgence of inflationary pressures, and to stand ready to adjust the policy stance, as needed. They welcomed reforms to improve the transmission of monetary policy and financial market deepening, which will help manage external financial volatility. Directors concurred that the external position is broadly in line with medium-term fundamentals, and that continued exchange rate flexibility and market-determined bond yields would be critical to help absorb external pressures.

Directors considered that the banking sector is broadly healthy and noted the progress made by Bank Indonesia and the financial sector supervisor, OJK, in assessing financial and corporate sector risks. They encouraged continued close monitoring of pockets of vulnerability, particularly from somewhat higher NPLs and from corporate external debt exposure. Directors welcomed the adoption of the Financial System Crisis Prevention and Mitigation (FSCPM) Law, which has strengthened the financial stability framework. They encouraged the authorities to make the law fully operational as early as possible with the issuance of relevant regulations and to ensure the continued full implementation of corporate hedging regulations.

\footnotetext{
2 At the conclusion of the discussion, the Managing Director, as Chairman of the Board, summarizes the views of Executive Directors, and this summary is transmitted to the country's authorities. An explanation of any qualifiers used in summings up can be found here: http://www.imf.org/external/np/sec/misc/qualifiers.htm.
} 
Directors welcomed the authorities' efforts and early successes in revamping the business climate. They encouraged further structural reforms to improve the business environment and boost private investment to support greater and more inclusive growth. In this context, Directors highlighted priority areas, such as expanding infrastructure, enhancing the regulatory framework, opening new sectors of the economy to investment, and closing labor skill gaps through improved education and a more flexible immigration regime for skilled workers. 
Indonesia: Selected Economic Indicators, 2012-2017

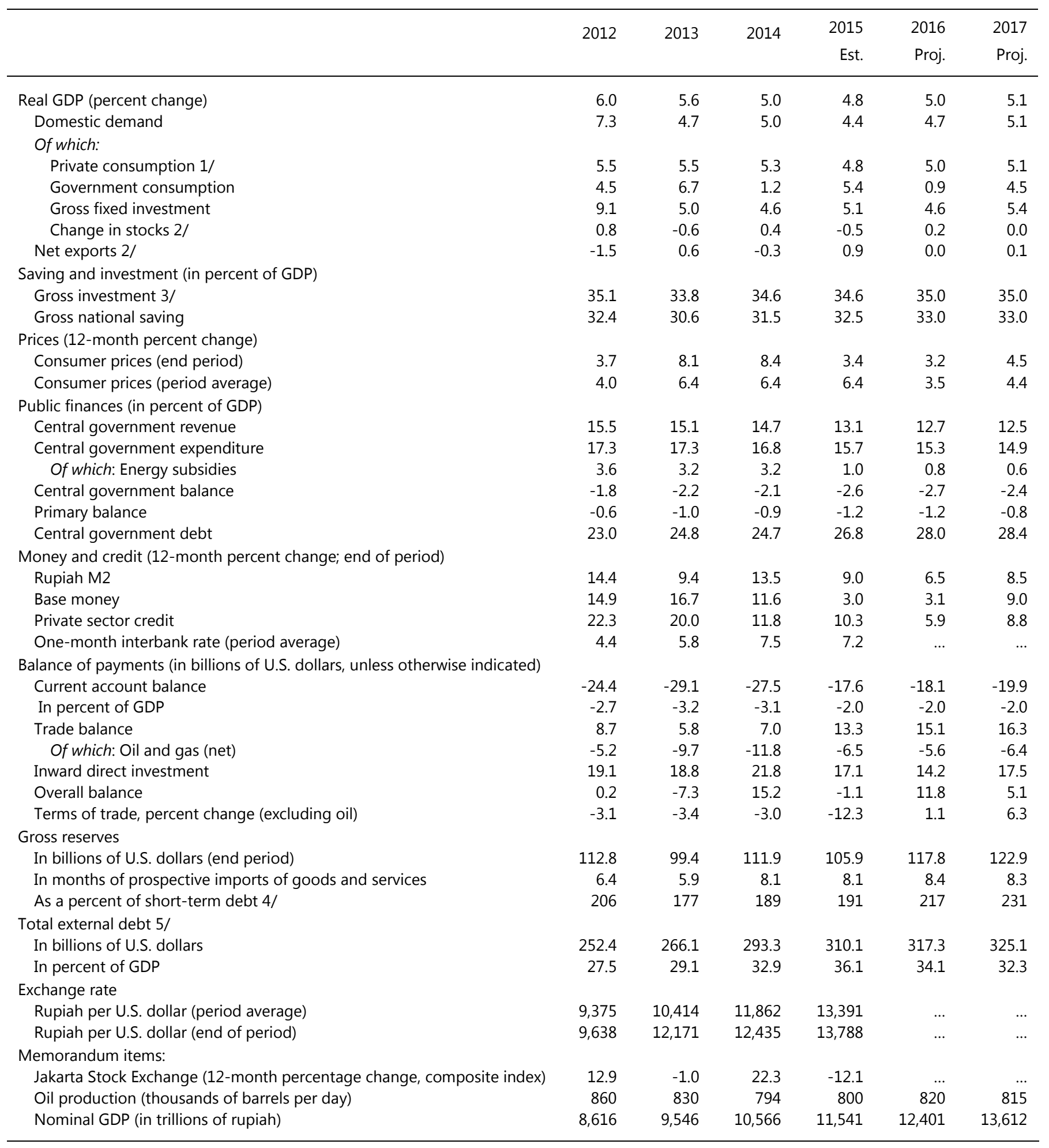

Sources: Data provided by the Indonesian authorities; and IMF staff estimates and projections.

1/ Includes NPISH consumption.

2/ Contribution to GDP growth (percentage points).

$3 /$ Includes changes in stocks.

4/ Short-term debt on a remaining maturity basis.

5/ Public and private external debt. 


\section{INTERNATIONAL MONETARY FUND}

\section{INDONESIA}

\section{STAFF REPORT FOR THE 2016 ARTICLE IV CONSULTATION}

December 27, 2016

\section{KEY ISSUES}

Context: The Indonesian economy continues to perform well, supported by robust growth and greater macroeconomic stability. A prudent mix of macroeconomic policies and structural reforms has helped the economy weather the commodity down-cycle and several episodes of emerging market (EM) financial turbulence. Securing and boosting growth in a more uncertain external environment requires maintaining policy buffers, while upgrading the medium-term framework through fiscal and structural reforms.

Near-term outlook: Growth in 2017 is projected to rise modestly to 5.1 percent, supported by robust private consumption. Inflation is expected to remain within the official target band, albeit slightly higher in 2017 due to lower electricity subsidies. The current account deficit would remain contained. The risks to the outlook have risen and are mainly external. External risks include uncertainties about the policies of the incoming United States administration, tighter global financial conditions, spillovers from a significant China slowdown, and lower commodity prices, which could intensify macro-financial vulnerabilities related to banks and corporates. Domestic risks include tax revenue shortfalls or higher domestic interest rates due to tighter global financial conditions, which could curb fiscal space.

Main policy recommendations: Strengthen the medium-term fiscal framework through tax policy and administration reforms, and continue to improve the effectiveness and efficiency of public spending. Monetary policy should stand ready to deal with changes in a more volatile external environment, while maintaining exchange rate and bond yield flexibility. It is important to fully implement the enhanced financial stability framework by issuing the regulations of the Financial System Crisis Prevention and Mitigation (FSCPM) Law, strengthen inter-agency coordination to respond to shocks, and address macro-financial vulnerabilities from the bank and corporate sectors. Deeper structural reforms are needed to improve the business environment further and support private investment. Finally, the policy strategy should continue to include actions to boost the economy's resilience, to allow it to prosper even if the external environment becomes choppier. 
Approved By Kenneth $\mathrm{H}$. Kang and Vivek Arora
Mission dates: November 7-18, 2016

Mission Team: Luis E. Breuer (Head), Elena Loukoianova, Seng Guan Toh, Jongsoon Shin (all APD), Hui Jin (FAD), Mariam El Hamiani Khatat (MCM), Yinqiu Lu (SPR), and John G. Nelmes (Senior Resident Representative). Kenneth $\mathrm{H}$. Kang (APD) joined part of the mission. Mr. Omar, Executive Director, participated in the concluding session. Agnes Isnawangsih and Nong Jotikasthira (APD) assisted in the preparation of this report.

\section{CONTENTS}

OVERVIEW

POLICY DISCUSSIONS

A. Fiscal Policy and Reforms-Growth-Enhancing Revenue and Expenditure Strategy

B. Monetary Policy and Foreign Exchange Management-Maintaining Stability

C. Financial and Corporate Sector Issues-Strengthening the Financial Stability Framework

D. Structural Reforms-Boosting Private Investment 20

STAFF APPRAISAL

\section{BOXES}

1. External Sector Assessment____ 25

2. Monetary Operation Reforms ___ 26

3. Update on Balance Sheet Analysis (BSA)___ 27

4. Private Investment in Indonesia ___ 28

\section{FIGURES}

1. Revenue Profile Related to Peers ___ 13

2. Macro-Financial Developments__ 30

3. Recent Market Developments ___ 32

4. Real Sector _ 33

5. External Sector___ 34

6. Fiscal Sector__ $\underline{35}$

7. Monetary Sector and Bank Liquidity Developments ___ $\underline{36}$

8. Selected Emerging Market Economies: Financial Soundness Indicators, 2016:Q2 ___ 37

9. Financial Soundness Indicators by Size of Commercial Banks__ 38

\section{TABLES}

1. Selected Economic Indicators, 2012-17

2. Selected Vulnerability Indicators, 2012-16 
3. Balance of Payments, 2012-17 $\underline{41}$

4. Medium-Term Macroeconomic Framework, 2014-21

5. Summary of Central Government Operations, 2012-17 (In trillions of rupiah)

6. Summary of Central Government Operations, 2012-17 (In percent of GDP) 44

7. Summary of General Government Operations, 2012-16 $\underline{45}$

8. Monetary Survey, 2012-17 $\underline{46}$

9. Financial Soundness Indicators, 2012-16 $\underline{47}$ 10. Key Poverty and Social Indicators $\underline{48}$

\section{APPENDICES}

I. Risk Assessment Matrix 49

II. External Sector Report $\underline{50}$

III. Debt Sustainability Analysis

51




\section{OVERVIEW}

1. Indonesia has maintained macroeconomic stability, while adjusting well to recent shifts in the external environment. A prudent mix of macroeconomic policies and the launch of structural reforms has helped the economy weather the commodity down-cycle, slow global growth, and several episodes of financial turbulence affecting EMs. While growth has slowed slightly, it has remained robust. Inflation has eased and the external position has improved. A gradual fiscal consolidation has begun. There has been major progress on the financial stability framework, and gaps related to the crisis management framework are being addressed. Structural reforms that began in 2015 so far have improved the business environment. Positive sentiment has been reflected in supportive capital inflows in 2016, which buoyed financial markets before undergoing some corrections starting in October. Since the United States (U.S.) elections and the December decision by the FED to raise interest rates, markets have accelerated the correction.

\section{Private consumption remains the main driver of growth, but higher inclusive growth} will require deeper structural reforms. Consumption growth has been underpinned by an expanding middle class, lower fuel prices, and falling inflation. Investment has remained subdued, reflecting spillovers from lower commodity prices, some excess capacity in mining and manufacturing, and structural impediments, while external demand has been weak. In staff's views, consumption-led growth can be sustained over the medium term, but meeting the authorities' ambitious targets for inclusive growth will require deepening structural reforms.

\section{Discussions focused on policies to strengthen the medium-term policy framework to} support inclusive growth, while preserving macro stability in an uncertain and volatile external environment. The challenge is to continue, and in some cases deepen, ongoing structural reforms that will boost productivity and growth, while maintaining and improving policy buffers to boost resilience in an increasingly uncertain and volatile external environment. Policy priorities include: (i) strengthening the medium-term fiscal framework with a growth-friendly revenue strategy and continuing to improve the effectiveness and efficiency of public spending; (ii) standing ready to adjust monetary policy to deal with changes in the external environment, while maintaining exchange rate and bond yield flexibility; (iii) implementing the enhanced financial stability framework, improving inter-agency coordination to respond to shocks, and sustaining vigilance on pockets of macro-financial vulnerabilities from the bank and corporate sectors; and (iv) deepening structural reforms to improve the business environment and support private investment.

4. Past Fund advice and the authorities' policies have been broadly aligned. In 2016, monetary policy easing was appropriately calibrated and there was progress with monetary operations reform. The authorities continue to pursue a flexible exchange rate policy. The FSCPM Law passed in March was a milestone for the financial stability architecture. On the fiscal front, however, the authorities decided to launch a tax amnesty to expand the revenue base and strengthen compliance instead of raising excises. 


\section{RECENT DEVELOPMENTS, OUTLOOK, AND RISKS}

\section{In 2016, growth remained strong, inflation dropped significantly, and the current account deficit was contained.}

- Growth remained robust at 5.0 percent in 2016:Q3 due to resilient private consumption, despite some modest fiscal consolidation and still weak private investment and external demand. Credit growth slowed to the lowest over the past few years on weak corporate demand, before slightly picking up recently.

- Headline inflation dropped to the bottom of the official target band (3-5 percent) - the lowest since end-2009—owing to stable food prices, lower administered prices, and a small negative output gap ( $1 / 2$ percent of GDP), with core inflation also moderating.

- The current account (CA) deficit remained contained at 2.1 percent of GDP in Q1-Q3:2016, due mainly to lower imports that more than offset lower exports. Official reserve assets rose to US $\$ 111.5$ billion at end-November (around 8 months of prospective imports), amid supportive portfolio inflows in the first three quarters of 2016.

6. The near-term outlook remains favorable. Growth in 2016 is projected at 5 percent on account of robust private consumption. In 2017, growth is expected to rise modestly to 5.1 percent, led by a gradual pickup in private investment in response to stronger commodity prices, low interest rates, and a recovery in external demand on the back of a pickup in global growth and trade. Inflation is expected to rise from 3.2 percent at end-2016 to around 4.5 percent at end-2017 largely due to lower electricity subsidies and some recovery in commodity prices. The CA deficit would remain at around 2 percent of GDP next year, with the expected pickup in fixed investment and imports offset by the impact of higher commodity prices on exports.

\section{Overall macro-financial risks appear more manageable, but pockets of risks remain.}

Macro-financial pressures have moderated slightly, aided by some recovery in commodity prices, portfolio inflows during much of 2016, and private external debt deleveraging. Indonesian financial markets experienced strong rallies until Q3:2016. The correction that began in October intensified after the U.S. election in November and the FED's decision to raise interest rates in December-in the period of November 8-December 16, equities fell by 4 percent, benchmark 10-year bond yields rose $70 \mathrm{bps}$, and the rupiah weakened 2.3 percent, with portfolio outflows. During this episode, financial market volatility was higher than following Brexit, but less than during the 2013 taper tantrum. Corporates' external borrowing has started to decline, after a rapid rise in previous years, and credit growth remains tepid. Corporate debt-at-risk with an interest coverage ratio less than 1 picked up somewhat this year. Banks' nonperforming loans (NPLs) have also risen, albeit from a low level, while liquidity remains tight in some smaller banks, and deposit growth slowed. Fiscal financing remains reliant on nonresident investment in local currency (LCY) government bonds and 
in global bond issues. ${ }^{1}$ The government successfully placed international bonds amounting to US\$3.5 billion in December 2016.
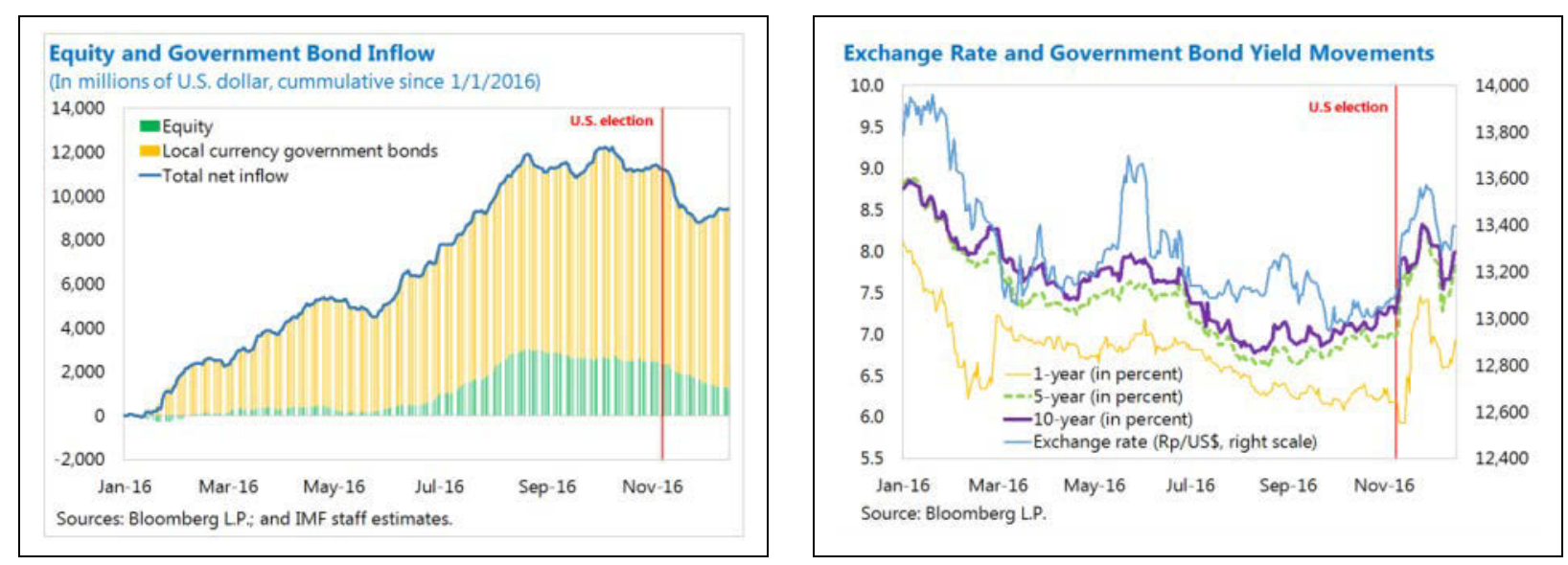

\section{Indonesia's external position in $\mathbf{2 0 1 6}$ is assessed to remain broadly consistent with} medium-term fundamentals and desirable policy settings (Box 1 , Appendix II). Staff estimates the current account gap to be between -0.8 and 1.2 percent of GDP, with the REER gap in the range of -6 percent to 4 percent. The main conclusion from the external and public DSA are broadly unchanged from the last Article IV (Appendix III). At 35.8 percent of GDP (about half of which is public) at end-September 2016, external debt remains at a moderate level. External financing has been sustainable, but remains sensitive to domestic and external volatility. At about 130 percent of IMF's reserve adequacy metric (projected for end-2016), reserves are expected to be sufficient to buffer most shocks.

9. Over the medium-term, the macroeconomic outlook is expected to improve. Growth is projected to increase to $5 \frac{1}{2} 2$ percent by 2020 , supported by a gradual recovery in fixed investment and ongoing structural reforms, with the output gap closing by 2018. International reserves are projected to gradually increase, with the reserve adequacy metric remaining broadly stable.

10. Under an illustrative enhanced reform scenario prepared by staff that involves a more growth-friendly fiscal policy, growth would rise to 6 percent by 2021, mainly on account of higher infrastructure and social spending, as well as to some productivity growth from capital accumulation and reforms.

11. Downside risks to the outlook have risen recently and are largely external. (Appendix I: Risk Assessment Matrix) The government and corporate sector's reliance on external financing makes Indonesia susceptible to global shocks and funding reversals. External risks include uncertainties around the policies of the incoming U.S. administration, tighter and more volatile global conditions, spillovers from a significant China slowdown, and lower commodity prices. In response to expectations for higher interest rates following the U.S. election and an increase in the

\footnotetext{
${ }^{1}$ For further information, see accompanying selected issues paper on "Capital Inflows to Indonesia Since the Global Financial Crisis."
} 
U.S. policy rate in December, sovereign and corporates could face higher funding costs, together with exchange rate depreciation and capital outflows. Domestic risks include a smaller fiscal buffer, reflecting tax revenue shortfalls or higher domestic interest rates due to tighter global financial conditions, which could curb fiscal space to support growth. Domestic political tensions associated with regional elections could also increase. A confluence of external and domestic factors could intensify pockets of macro-financial vulnerabilities related to the banking and corporate sectors. Upside risks include stronger global growth and higher commodity prices, aided by an expected fiscal stimulus in the United States.

12. In the event of severe external pressures, tighter aggregate demand management and continued exchange rate flexibility could help contain risks. International reserves should be used primarily to prevent disorderly market conditions, provided that reserves remain adequate (Appendix I: Risk Assessment Matrix). If international financial markets were to be closed to EMs for a protracted period of time, targeted measures to alleviate funding pressures by banks and corporates would help preserve financial stability. Contingent financing totaling about US\$83 billion is currently available, inclusive of the Chiang Mai Initiative Multilateralization and bilateral swap arrangements.

\section{Authorities' Views}

\section{The authorities broadly agreed with staff on the macroeconomic outlook. The} authorities reaffirmed their commitment to maintain macroeconomic and financial stability, while enhancing the medium-term framework to raise growth potential. Growth is projected to strengthen in 2017, underpinned by a recovery in private investment, with exports also expected to benefit from the recent strong rebound in coal and palm oil prices; inflation and related expectations remain at multiyear lows; and the CA deficit is expected to remain well contained, while reserve buffers have risen considerably. In their views, these developments, coupled with a flexible policy framework, contingency plans, and a range of available contingent financing place Indonesia in a strong position to manage the downside risks emanating primarily from outside the country.

\section{POLICY DISCUSSIONS}

\section{A. Fiscal Policy and Reforms-Growth-Enhancing Revenue and Expenditure Strategy}

14. The government's fiscal strategy centers on broadening the revenue base and expanding priority expenditures, while making them more efficient within the statutory fiscal deficit limit of 3 percent of GDP. The government aims to mobilize tax revenue by strengthening tax collection efforts, simplifying layers of exemptions, and broadening the tax base. The authorities also intend to continue reallocating unproductive spending and improving the efficiency of spending, including on infrastructure, social programs, and transfers to local governments. Following the landmark 2015 fuel subsidy reforms, the government has continued to reform energy subsidies, including electricity and diesel, and improve the targeting of rice subsidies. The retail prices of diesel 
and other fuels are being adjusted on a quarterly basis. Aided by these efforts and the planned tax reform, the government aims to gradually lower the fiscal deficit to $2 \frac{1}{4}$ percent of GDP over the medium term, to rebuild buffers and strengthen the fiscal sector's resilience to outside shocks.

\section{In August 2016, the authorities began a gradual fiscal consolidation while protecting}

the government's priorities. Weak revenues had pushed the fiscal deficit to 1.8 percent of annual GDP in 2016:H1, requiring lower spending in $\mathrm{H} 2$ to stay within the deficit rule of 3 percent of GDP. In addition to weak commodity-related revenues, nonoil revenues-particularly Value Added Tax (VAT) and excise taxes-continue to underperform, exacerbating Indonesia's structurally low tax revenues. Against this backdrop, the Cabinet approved a revised financial plan in August 2016, with more realistic revenue projections and lower spending, that staff project will lead to a fiscal deficit of about 2.7 percent of GDP. Collections from the amnesty program ${ }^{2}$ surprised on the upside (Rp 99.2 trillion or 0.8 percent of GDP as of November 30 ), coming mainly from previously undeclared domestic assets; for 2016 as a whole, tax amnesty collections are projected to reach 0.9 percent of GDP. Building on the success of the amnesty, the government intends to

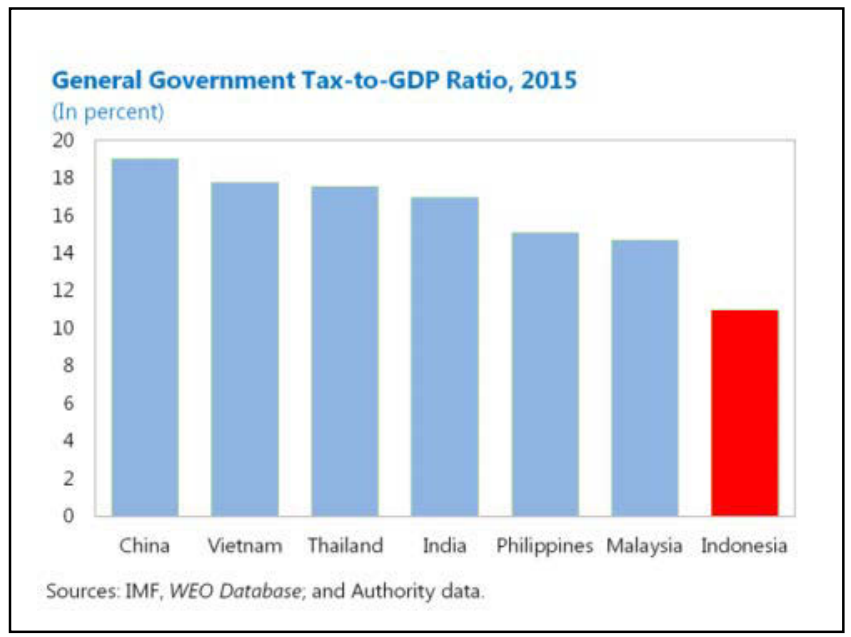
expand the tax base and strengthen relations and trust between the private sector and the tax administration.

\section{The $\mathbf{2 0 1 7}$ budget targets higher revenue, more efficient spending in priority areas, and} a lower fiscal deficit. The 2017 budget increases nominal tax collections by around 13 percent, on stronger collection efforts and expanded tax base. The authorities plan to upgrade the main tax laws in 2017, including VAT and income tax laws, while using the information gathered from the tax amnesty combined with external databases to guide audits. The budget continues to relocate operational spending to priority areas, including infrastructure, education, and health, reduces and better targets electricity subsidies for the poor, and increases transfers to local governments for infrastructure. The fiscal deficit target of 2.4 percent of GDP will help rebuild fiscal buffers.

\section{Staff Position}

17. The government's fiscal strategy is well-placed. Staff welcomes the government's overall fiscal strategy. The revised financial plan approved in August 2016 was appropriate in light of weak revenues and higher external volatility. The authorities should continue to improve targeting of subsidies and reduce operational spending, while protecting priority spending. Ongoing expenditure

\footnotetext{
2 The tax amnesty program, which runs from July 2016 to March 2017, aims at boosting tax revenues, repatriating capital held by Indonesians abroad, and improving relations of taxpayers with the tax office.
} 
reviews in agriculture, health, and education are expected to improve efficiency, which will strengthen the medium-term fiscal framework and contribute to growth.

\section{While Indonesia has some fiscal space to expand spending, the decision to rebuild} fiscal buffers in $\mathbf{2 0 1 7}$ by targeting a lower fiscal deficit is appropriate. A range of indicators point to the availability of fiscal space, even within the existing fiscal rule, including relatively small financing needs and deficit levels, low inflation and credit growth, and a sustainable external position. However, in the current context, the authorities' plan to rebuild fiscal buffers by lowering the fiscal deficit target in 2017 and rationalizing spending to achieve a sustained lower primary deficit is appropriate. These policies will support the economy's resilience to shocks, which is needed if Indonesia is to prosper in a more volatile external environment. Meeting the authorities' revenue targets for 2017 will be challenging. If revenue shortfalls persist, additional revenue actions will be needed to maintain the planned level of spending and meet the deficit target.

\section{There is room to strengthen the medium-term fiscal framework to promote} productivity gains and growth. Public investment in infrastructure and expansion of social spending, especially health and education, can catalyze other key drivers for medium-term growth, supplemented by improving the efficiency of public expenditure. To achieve these, fiscal buffers need to be strengthened, within the fiscal rule, buttressed by additional revenue measures from tax policy and administration reforms. Higher domestic revenue mobilization will gradually reduce reliance on external financing. Finally, moving to more frequent adjustments of retail fuel prices through a transparent fuel pricing mechanism would also protect the budget from upward changes in international oil prices.

20. In an illustrative reform scenario prepared by staff, where both revenue and expenditure would increase by around 3 percentage points of GDP by 2021, potential growth would increase to 6 percent by 2021. This result is similar to the experience of other EMs which implemented growthfriendly fiscal reforms. (text table). ${ }^{3}$

\footnotetext{
${ }^{3}$ For further information, see the accompanying selected issues on "Deepening the Growth-Enhancing Fiscal Strategy."
} 
Indonesia: Illustrative Growth-Enhancing Fiscal Strategy Versus Baseline Forecast

\begin{tabular}{|c|c|c|c|c|c|c|}
\hline & \multirow[b]{2}{*}{2015} & \multirow[b]{2}{*}{2016} & \multicolumn{2}{|c|}{ Baseline } & \multicolumn{2}{|c|}{$\begin{array}{c}\text { Illustrative } \\
\text { Scenario: } \\
\text { Growth- } \\
\text { Enhancing } \\
\text { Fiscal Strategy }\end{array}$} \\
\hline & & & 2017 & 2021 & 2017 & 2021 \\
\hline General government revenue & 14.9 & 14.5 & 14.3 & 14.3 & 14.8 & 17.3 \\
\hline Central government revenues and grants & 13.1 & 12.8 & 12.5 & 12.5 & 13.0 & 15.3 \\
\hline Of which: tax revenues & 10.7 & 11.0 & 10.6 & 10.7 & 11.1 & 13.5 \\
\hline Oil and gas revenues & 1.1 & 0.7 & 0.9 & 0.7 & 0.9 & 0.7 \\
\hline Non-oil and gas revenues & 11.9 & 12.0 & 11.6 & 11.7 & 12.1 & 14.5 \\
\hline Tax revenues & 10.3 & 10.6 & 10.2 & 10.4 & 10.7 & 13.2 \\
\hline Income tax & 4.8 & 5.5 & 5.2 & 5.4 & 5.2 & 5.4 \\
\hline VAT & 3.7 & 3.4 & 3.5 & 3.4 & 3.8 & 5.2 \\
\hline Excise & 1.3 & 1.1 & 1.1 & 1.2 & 1.3 & 2.2 \\
\hline Other & 0.6 & 0.6 & 0.5 & 0.4 & 0.5 & 0.4 \\
\hline Nontax revenues & 1.5 & 1.5 & 1.4 & 1.4 & 1.4 & 1.4 \\
\hline Local government revenue net of transfer & 1.8 & 1.8 & 1.8 & 1.8 & 1.8 & 2.0 \\
\hline General government expenditure & 17.4 & 17.2 & 16.7 & 16.8 & 17.2 & 19.5 \\
\hline Health & 1.3 & 1.5 & 1.5 & 1.5 & 1.6 & 2.1 \\
\hline Education & 3.5 & 3.3 & 3.3 & 3.3 & 3.5 & 4.1 \\
\hline Social Assistance & 1.5 & 1.7 & 1.7 & 1.7 & 1.7 & 1.8 \\
\hline Infrastructure & 2.2 & 2.7 & 2.4 & 2.5 & 2.7 & 3.8 \\
\hline Other expenditure & 8.8 & 8.1 & 7.7 & 7.8 & 7.7 & 7.7 \\
\hline General government deficit & -2.5 & -2.7 & -2.4 & -2.5 & -2.4 & -2.2 \\
\hline General government debt & 26.8 & 28.0 & 28.4 & 29.4 & 28.3 & 28.4 \\
\hline Real GDP Growth & 4.8 & 5.0 & 5.1 & 5.5 & 5.2 & 6.0 \\
\hline
\end{tabular}

Source: World Bank; Indonesian authorities; and IMF staff estimates.

\section{Growth-Friendly Revenue Strategy}

\section{There is scope to mobilize non-oil revenues through growth-friendly tax policy and} administration reforms. Since 2012, total general government revenue has fallen by 2.5 percentage points of GDP, mainly due to lower production and prices of petroleum products, and, more recently, import contraction also affecting VAT receipts. At the same time, non-oil revenue in percent of GDP remains weak at around its 2004 level. There is substantial scope to mobilize tax revenue (see table) - the most growth-friendly tax is the property tax, followed by indirect taxes (including excise taxes and VAT), Personal Income Tax (PIT), and Corporate Income Tax (CIT). ${ }^{4}$ The following illustrative revenue mobilization strategy could be pursued in the near to medium term:

\footnotetext{
${ }^{4}$ IMF, 2015, "Fiscal Policy and Long-Term Growth," IMF Policy Paper (Washington).
} 
Menu of Policy Options in Growth-Enhancing Fiscal Strategy

(In percent of GDP)

\begin{tabular}{|c|c|c|}
\hline Policy Options & $\begin{array}{l}\text { Estimated } \\
\text { Fiscal } \\
\text { Impact by } \\
2021\end{array}$ & Details of the Policy \\
\hline Total revenue policy $1 /$ & 3.0 & \\
\hline Value-added tax & 1.8 & Increase rate from 10 percent to 15 percent while removing exemptions. \\
\hline Excise taxes & 1.0 & Increase vehicle and tobacco excise rates and impose environmental tax on fuel. \\
\hline Personal income tax & 0.0 & Remove exemptions and lower top rate in a revenue-neutral manner. \\
\hline Corporate income tax & 0.0 & Remove exemptions and lower statutory rate in a revenue-neutral manner. \\
\hline Property tax & 0.2 & Increase rate and gradually replace transaction tax with recurrent property tax. \\
\hline Total expenditure policy $2 /$ & 2.7 & \\
\hline Health & 0.6 & Implement universal health coverage while improving efficiency. \\
\hline Education & 0.8 & Increase education expenditure toward EM average ( 4.8 percent of GDP) while improving efficiency \\
\hline Social Assistance & 0.1 & Consolidate poorly-targeted programs. \\
\hline Infrastructure & 1.3 & Increase investment expenditure toward 5 percent of GDP while improving efficiency. \\
\hline Other expenditure & -0.1 & Cut nonpriority expenditure. \\
\hline
\end{tabular}

- Excise tax rates on vehicle and tobacco could be increased in the near term, while simplifying the complicated structure of tobacco excises over the medium term. A new environmental tax on fuel products could be imposed, as both the retail price and the net tax of gasoline and diesel are relatively low in Indonesia.
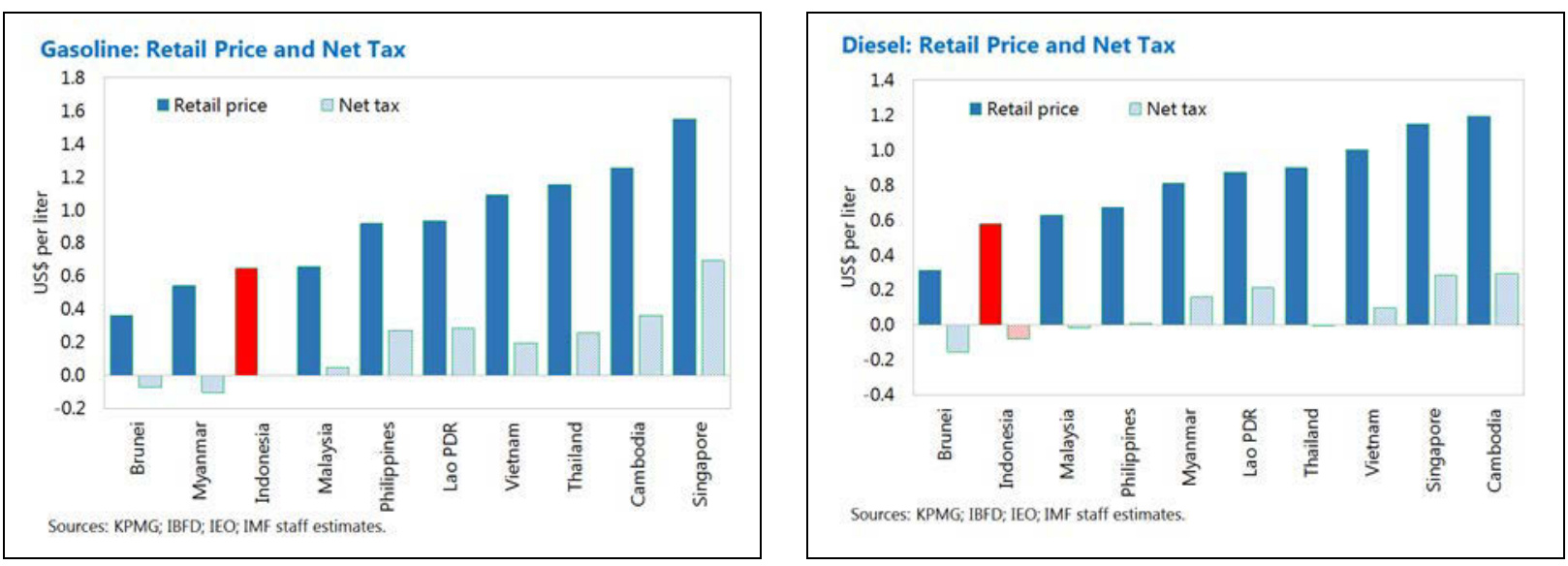
- The VAT rate could be gradually raised, with VAT administration simplified. Revenue potential from VAT is the greatest, given that the current rate is 10 percent, well below those in OECD and large EM countries. The VAT rate could be raised gradually to 15 percent, taking into account the cyclical position of the economy, coupled with a removal of VAT exemptions (including on intermediate services), while administration is gradually simplified.

- PIT base could be broadened by a lower threshold for the top rate, while capitalizing on asset declarations under the amnesty.

- The removal of untargeted tax incentives and unifying low-rate regimes into one single CIT rate should be pursued. Lowering the CIT rate significantly is not advisable. At 25 percent, the statutory CIT rate appears appropriate compared to other countries, and as large countries such as Indonesia have little to gain from a lower CIT rate.

- Higher rates on real property tax could be explored in the near term, while taking into account that this tax has been decentralized to local governments. In the medium term, the assessment of property values could be strengthened, and the local stamp duty (transaction tax) could be gradually replaced by a recurrent real property tax.

- International aspects of taxation should be reviewed. There is room to strengthen anti-tax avoidance regulations such as those on permanent establishment, transfer pricing, thin capitalization, and controlled foreign corporations. Implementation of the OECD-G20 BEPS project needs to be adapted to Indonesia's circumstances. ${ }^{5}$

\section{Tax administration reforms are an important element of a growth-friendly fiscal} policy. In particular, actions should aim to lower compliance costs and render tax administration more business-friendly, including by removing ambiguities and inconsistencies in the interpretation of tax laws and simplifying VAT filing and refund requirements. The current focus on strengthening the tax administration through incremental reforms, rather than undergoing a potentially disruptive reform of establishing a Semi-Autonomous Revenue Authority (SARA), is well-placed. Tax collection efficiency can be improved by enhanced risk management, extended audit coverage through more specific-issue audits, and moving the Extensification program (comprising efforts to increase the number of registered taxpayers) towards a more targeted campaign.

\footnotetext{
${ }^{5}$ For further information, see the accompanying selected issues on "International Tax Reform in Indonesia."
} 


\section{Figure 1. Indonesia: Revenue Profile Related to Peers}

Government revenue has trailed behind peers, with declining oil revenue and constrained nonoil revenues...
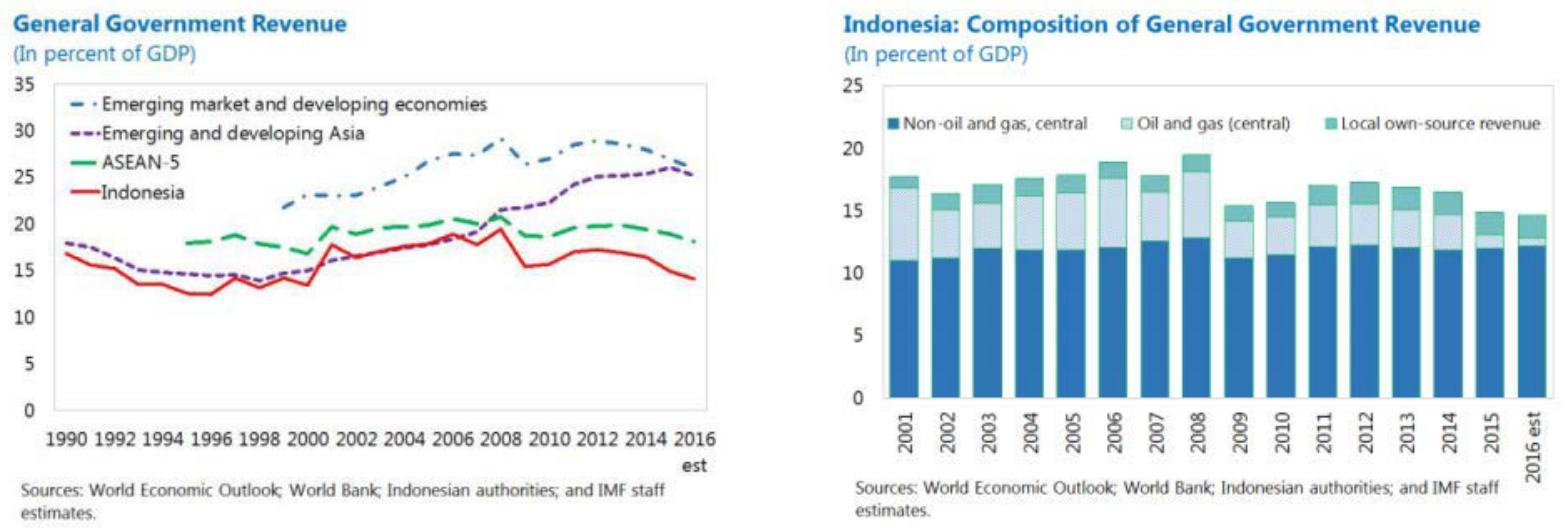

... low tax productivity and efficiency suggest room to remove exemptions and improve tax administration.
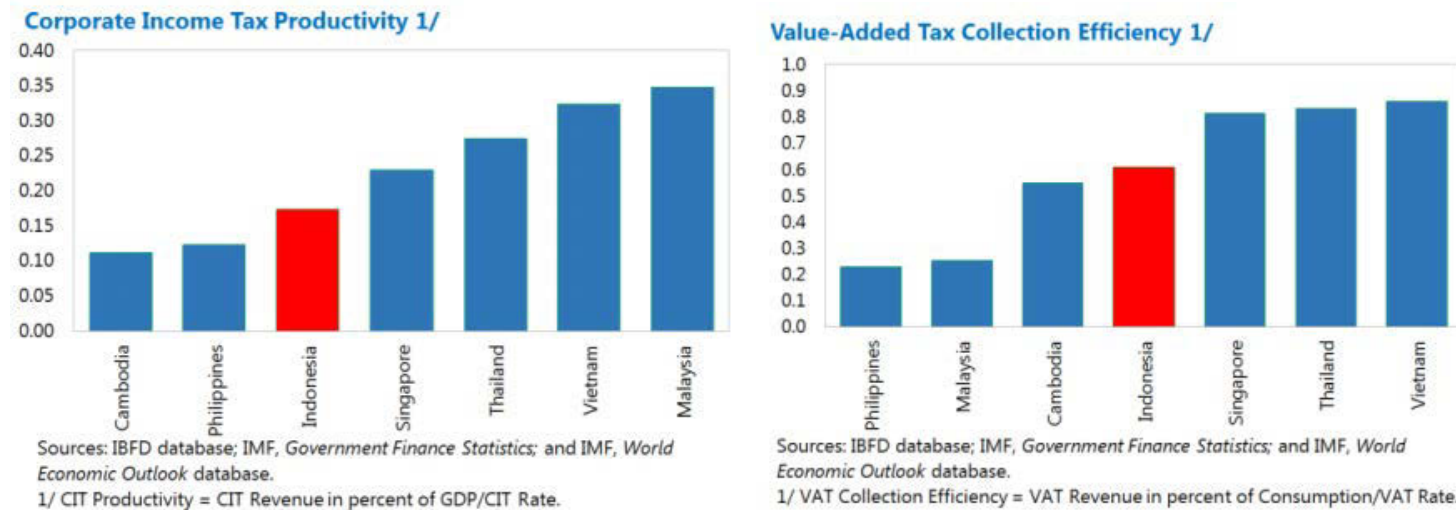

Sources: IBFD database; IMF, Government Finance Statistics; and IMF, World Economic Outlook database.

1/ VAT Collection Efficiency $=$ VAT Revenue in percent of Consumption/VAT Rate.

While the CIT rate is in line with peers, there is room to increase the VAT rate.
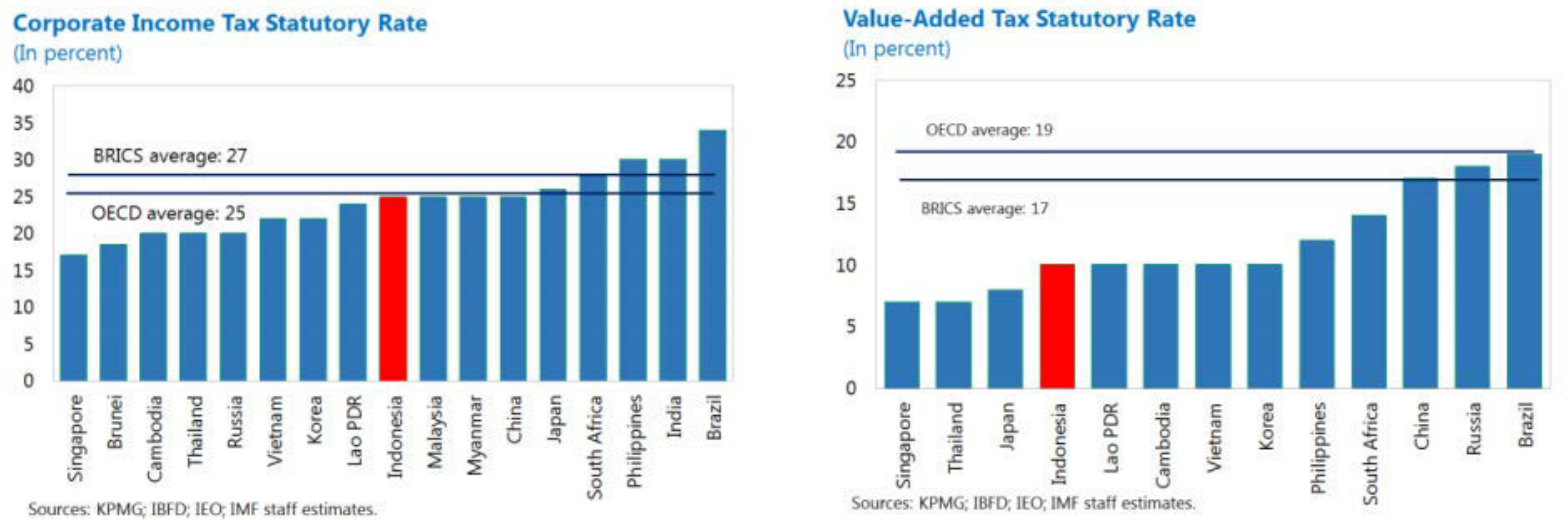


\section{Growth-Enhancing Expenditure Strategy}

23. Higher expenditure in selected areas will support inclusive growth. Constrained by weak revenues, Indonesia lags compared to the rest of ASEAN in spending on growth-critical areas such as infrastructure, health and education.

- Infrastructure development should continue, supported by stronger coordination and close monitoring. Improving the infrastructure investment framework is critical to improving the efficiency and integrity of scaling-up of investment. With increasing fiscal transfers to local governments, the capacity of regional governments should be enhanced in tandem. As state-owned enterprises (SOEs) are increasing capital

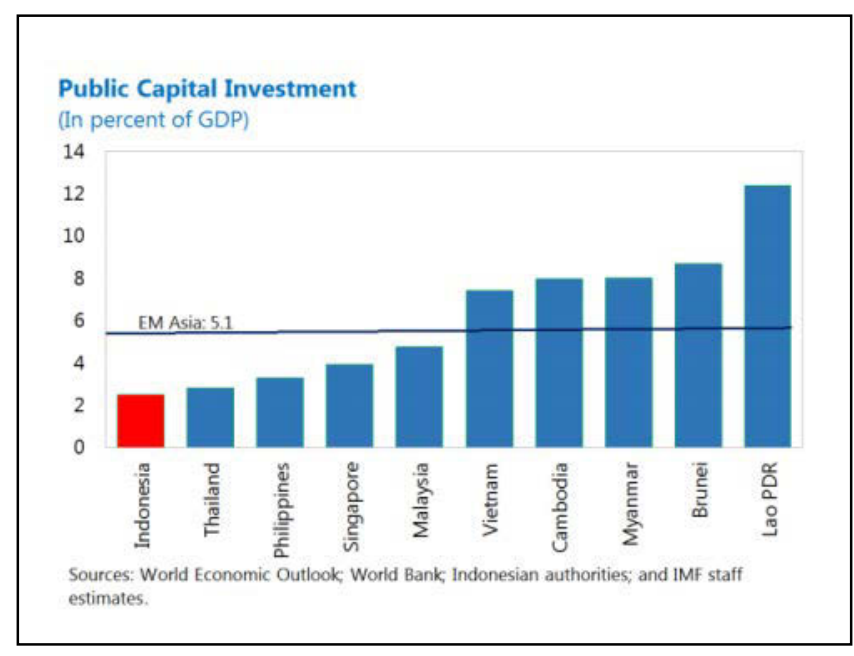
spending and there are plans to create six large SOE holding companies, it is important to closely monitor their balance sheets and assess their strategic role to ensure that SOEs do not crowd out private investment. The authorities should also closely monitor contingent liabilities from public-private partnerships (PPPs), where some large projects were recently launched or announced.

- Health and education spending could further expand. Indonesia's spending in health and education was 1.3 percent and 3.5 percent of GDP in 2015, respectively, well below the EM Asia average of 4.4 percent and 4.8 percent of GDP. As additional fiscal space is generated over the medium term and in response to Indonesia's demographic and social needs, spending in these sectors should increase to levels closer to peers. In the near term, the ongoing review of the efficiency of public spending in education, health, and agriculture will help improve its impact and lay the basis for a gradual expansion of social spending. Recommendations from the reviews should be implemented expeditiously.
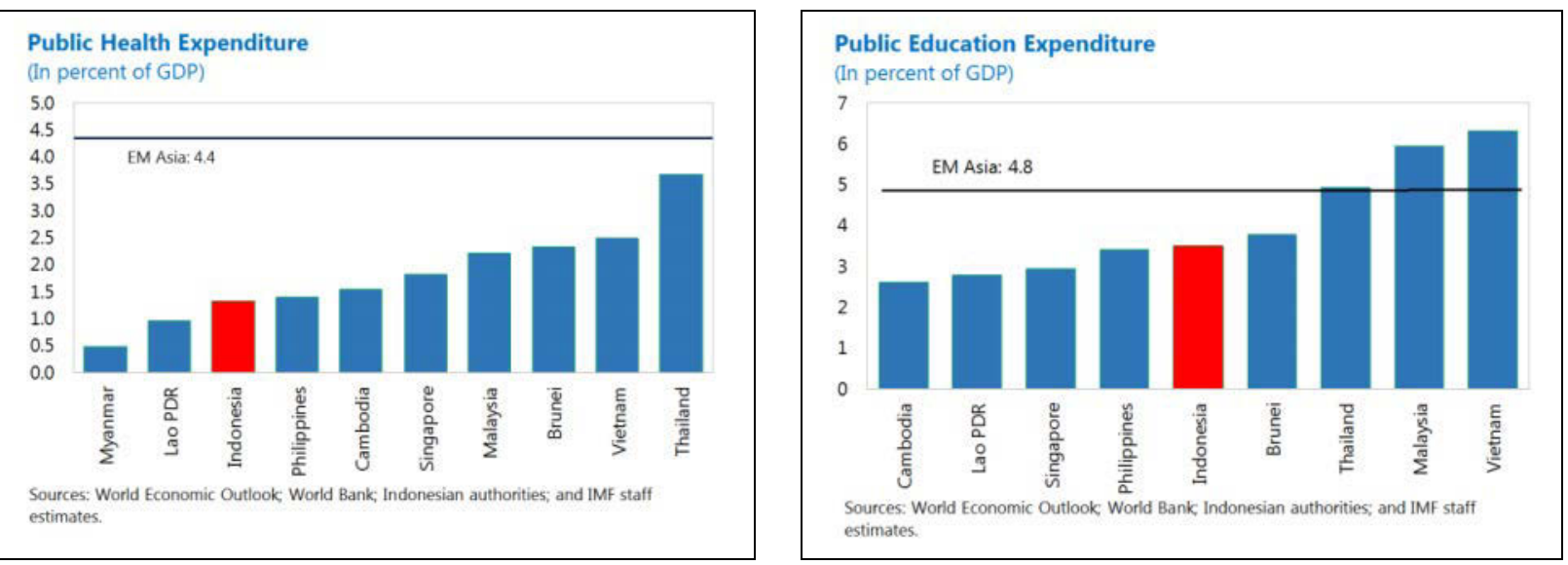
- The efficacy of social protection programs has room to improve through consolidation and expansion of those found to be effective. This would entail the reduction and consolidation of various social assistance and subsidy programs, and the expansion of conditional cash transfers, taking advantage of the updated integrated database. ${ }^{6}$

24. Further actions on public financial management (PFM) reforms would enhance the efficiency and integrity of public spending. The authorities are working to improve coordination with local governments and establish incentives to boost infrastructure investment by local government, which are welcome and should continue. Carrying out a comprehensive review of the public investment process at all levels of government may identify measures to improve the efficiency and efficacy of the public investment process.

25. The government's ambitious infrastructure program should be supported by further financial development. The program aims to mobilize a broad base of investors, including domestic institutional investors and banks, and introduce new financial instruments. In this context, it will be important to ensure that the program does not relax prudential standards that in turn could lead to excessive risk.

\section{Authorities' Views}

26. The authorities broadly agreed with staff's assessment and described their actions to support growth. A sound financial plan for 2016 approved in August 2016 enabled more realistic revenue projections and a streamlined expenditure envelope, aimed at strengthening fiscal buffers. By streamlining less-productive spending, they improved expenditure composition with a focus on growth-enhancing areas, including critical infrastructure projects and better targeted energy subsidies. These efforts, combined with potential for further revenue-raising reforms in the near to medium term, can support fiscal consolidation while protecting spending that is catalytic for growth.

27. The authorities concurred that revenue mobilization will be challenging but they are confident that the $\mathbf{2 0 1 7}$ targets will be met. The authorities agreed on the need to build buffers, and noted that they had prepared spending contingency plans, should tax revenues be lower. They noted that tobacco excises were again increased in the 2017 budget. The authorities indicated that a tax reform group will be formed to develop a comprehensive plan to upgrade the main tax laws in 2017. The authorities also concurred with the view that effective enforcement would be critical following the amnesty to reap the full benefits from the effort.

\section{B. Monetary Policy and Foreign Exchange Management-Maintaining Stability}

28. In 2016, Bank Indonesia (BI) eased monetary policy, which remains accommodative, and broadly maintained exchange rate flexibility. BI has cut policy rates by a cumulative 150 bps

\footnotetext{
${ }^{6}$ For further information, see the accompanying selected issues on "Reforming the Social Safety Net."
} 
in 2016, in response to falling inflation and, until very recently, reduced external pressures on the rupiah. The cuts were accompanied by reduced reserve requirements to create space for credit. Exchange rate flexibility has been broadly maintained, with some intervention during episodes of inflow surges and outflows to prevent disorderly market conditions, including the latest bout of EM volatility in November.

29. Important progress has been made in monetary operation reforms (Box 2). Effective August 19, 2016, BI shifted the policy rate to a transactional one (the 7-day reverse repo rate), to strengthen the transmission mechanism of monetary policy and facilitate financial deepening. BI also narrowed the interest rate corridor between the overnight Lending Facility and Deposit Facility. The transition was smooth, and early indicators on the transmission have been favorable, with interbank rates moving closer to the new policy rate.

\section{Staff Position}

30. The current monetary stance is broadly adequate. The latest decisions by the BI to hold policy rates in November and December were appropriately calibrated with inflation remaining within the target band and greater market volatility. While inflation in 2017 is projected to remain within the official target band, albeit higher than in 2016 due to the elimination of subsidies and some recovery of commodity prices, the authorities should remain vigilant to the resurgence of inflationary pressures and stand ready to adjust the policy stance, as needed. In the event of spillovers from severe external volatility affecting the currency and related inflation expectations, BI is encouraged to review its policy stance and adjust it to contain second-round inflationary pressures.

\section{BI's ongoing monetary operations reforms will support financial market deepening.}

The decision to move to reserve requirement averaging in the second half of 2017 will help improve banks' liquidity management.

\section{Continued exchange rate flexibility and market-determined bond yields are critical to} help absorb external pressures that may arise. Keeping this flexibility will be important to allow the economy to adjust smoothly to volatile external conditions. FX intervention should continue to be used primarily to prevent disorderly market conditions, provided that reserves remain adequate. The authorities' handling of capital outflows in the recent period has been broadly consistent with the Fund's Institutional View on capital flows.

\section{Authorities' Views}

33. The authorities are cognizant of heightened financial volatility facing EMs and were prepared to react to the changing external environment. The authorities saw some additional room to reduce policy rates further when conditions are appropriate, given moderate inflation, a negative output gap, and downside risks to growth in 2016. They viewed that credit growth, which has continued to slow for several years, has reached levels that were less than fully consistent with growth fundamentals, but also noted that the shift to the capital markets in financing over the past 
year had provided a partial offset. The authorities affirmed that exchange rate and bond yield flexibility would continue to be maintained as part of a prudent policy mix to absorb external pressures that may arise, supported by improved FX market hedging regulations. Furthermore, they noted that the domestic FX market for the last two years has been more liquid and the price discovery processes of the currency driven by market forces.

\section{Financial and Corporate Sector Issues-Strengthening the Financial}

\section{Stability Framework ${ }^{7}$}

\section{Financial soundness indicators suggest that the banking sector is broadly healthy,} albeit with areas of vulnerabilities. The high level of banks' capital and profitability has helped weather slowing economic growth. On average, the banking system is well capitalized and profitable, with a capital adequacy ratio (CAR) of 23.3 percent and returns on assets (ROA) of 2.4 percent (as of August 2016). However, soundness varies across different types of banks. Some smaller banks are more vulnerable to a liquidity shock, due to their higher reliance on short-term time deposits and limited access to the money market. The financial system as a whole remains liquid. Some sources of vulnerabilities include the rise in NPLs, special mention loans (SMLs), and restructured loans, although there are early signs that these are stabilizing. ${ }^{8}$ Higher NPLs are related mainly to manufacturing and trade, while NPLs in mining further increased.

\section{Risks from the corporate sector have somewhat moderated, but they remain elevated}

(Box 3). Corporate vulnerabilities stem from a relatively high level of foreign currency denominated (FX) debt exposures, elevated distressed debt, and lower cash buffers. FX risk of corporate debt has mitigated somewhat due to the slight decline in external borrowing and deleveraging, following weak investment appetite and business consolidation, as well as by the full implementation of BI hedging regulations. ${ }^{9}$ Profitability has improved slightly, supported by cost-cutting and postponement of investment projects. Nonetheless, corporate performance has varied across sectors, with commodity related sectors slightly recovering and manufacturing remaining weak.

\footnotetext{
7 The Financial Sector Assessment Program (FSAP) Report will be discussed separately at the Board later in 2017.

${ }^{8}$ NPLs rose to 3.1 percent of total loans in September 2016 (end-2015: 2.4 percent), SMLs at 5.4 percent (end-2015: 4.9 percent); and the share of restructured loans in total loans more than doubled to 5.1 percent between April 2015 and September 2016.

${ }^{9}$ The hedging regulations consist of (i) the minimum hedging ratio, which requires 25 percent of the net foreign currency liabilities with a maturity period up to three months, and those that mature between three and six months; (ii) the minimum liquidity ratio, requiring 70 percent of short-term foreign currency assets and short-term foreign currency liabilities; and (iii) a credit rating of no less than BB or equivalent issued by an authorized rating agency.
} 

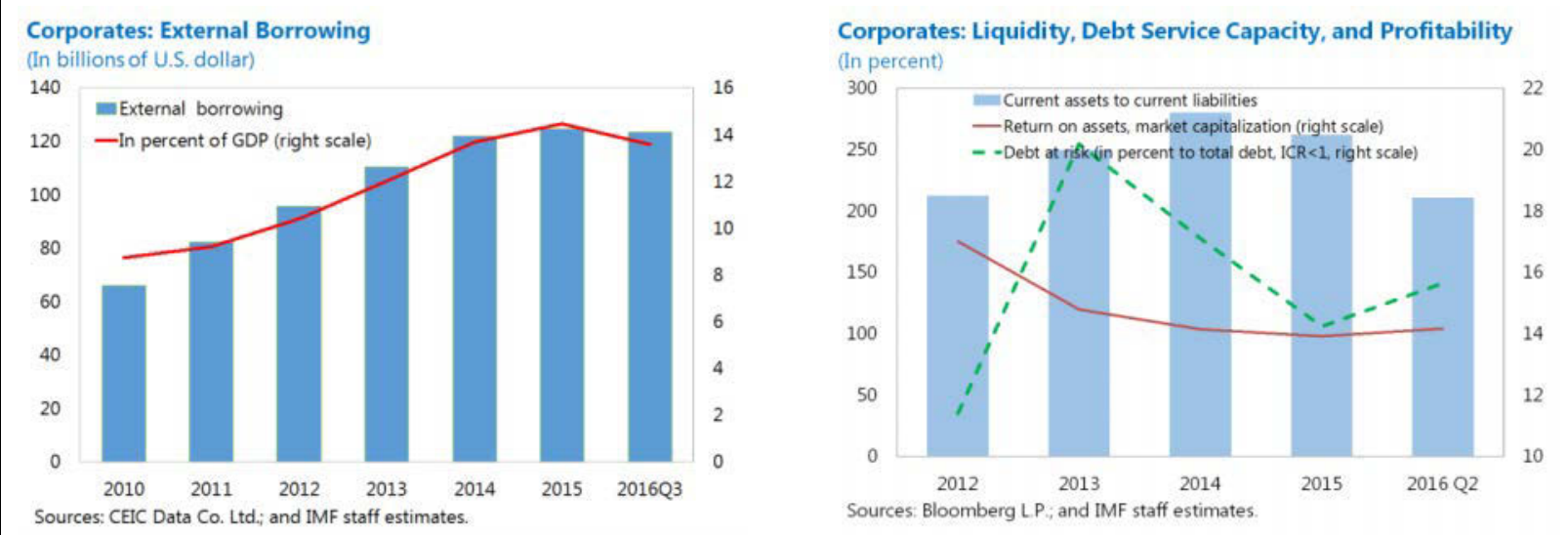

36. The economy is at a late stage of the credit cycle. Credit growth declined to 6.3 percent in October 2016 from 10 percent at end-2015, but appears to have bottomed out recently. FX loans have declined. Credit growth to corporates varies by sector, with weakness in mining and manufacturing, and robust growth in construction. Sluggish credit growth has been mainly driven by weak corporate credit demand, reflecting low investment. At the same time, some institutions, particularly medium-sized banks, have tightened their lending standards given higher NPLs, but conversely, credit expansion in large state-owned banks remains relatively robust. Some firms have also been shifting financing sources from banks to capital markets, which can partially explain lower lending from banks. Consumer loan growth has similarly slowed down in recent years.

\section{The authorities have further unwound part of an earlier tightening of macroprudential} policies undertaken in 2012-13. ${ }^{10}$ The unwinding includes easing loan-to-value (LTV) limits on mortgage loans and down payments on auto loans, and raising the floor of banks' loan-to-funding ratios that would incur reserve requirements. ${ }^{11} \mathrm{BI}$ has introduced a counter-cyclical capital buffer (CCB) in January 2016, currently set at zero.

\section{The adoption of FSCPM Law in April 2016 has strengthened the financial stability}

framework. The law defines domestic systemically important banks (D-SIBs), and provides a legal basis for crisis response and bank resolution. The authorities are now focusing on issuing the implementing regulations before April 2017 to make the law fully operational. These include regulations on recovery planning (OJK); and bank restructuring and resolution of systemic and nonsystemic banks (the Deposit Insurance Corporation (LPS) and OJK); and short-term lending facility (BI). The authorities have continued enhancing the integrated supervision of banks and nonbanks and upgrading risk-based supervision. Reflecting Basel III requirements, liquidity coverage

\footnotetext{
10 The tightening in 2012-13 aimed to address systemic financial stability risks from rapid credit growth, which peaked at almost 30 percent in 2012.

11 This is the second round of unwinding since 2015, and in order to maintain prudence and macro-financial stability, the relaxation is only applied to banks with NPL ratios under 5 percent.
} 
ratio (LCR) requirements are being adopted to help banks manage liquidity risk, besides a number of other liquidity ratios monitored by the authorities.

39. Financial deepening remains a priority of the government. Financial deepening in recent years has been slower than in peer EMs, constrained by a segmented banking system, shallowness of the financial markets, and low financial inclusion. Nonetheless, over the past decade the local currency government bond market has seen growth in depth and range of investor participation, including from foreign investors. The authorities have created a high-level coordinating committee comprising the key public agencies to intensify coordination on financial deepening.

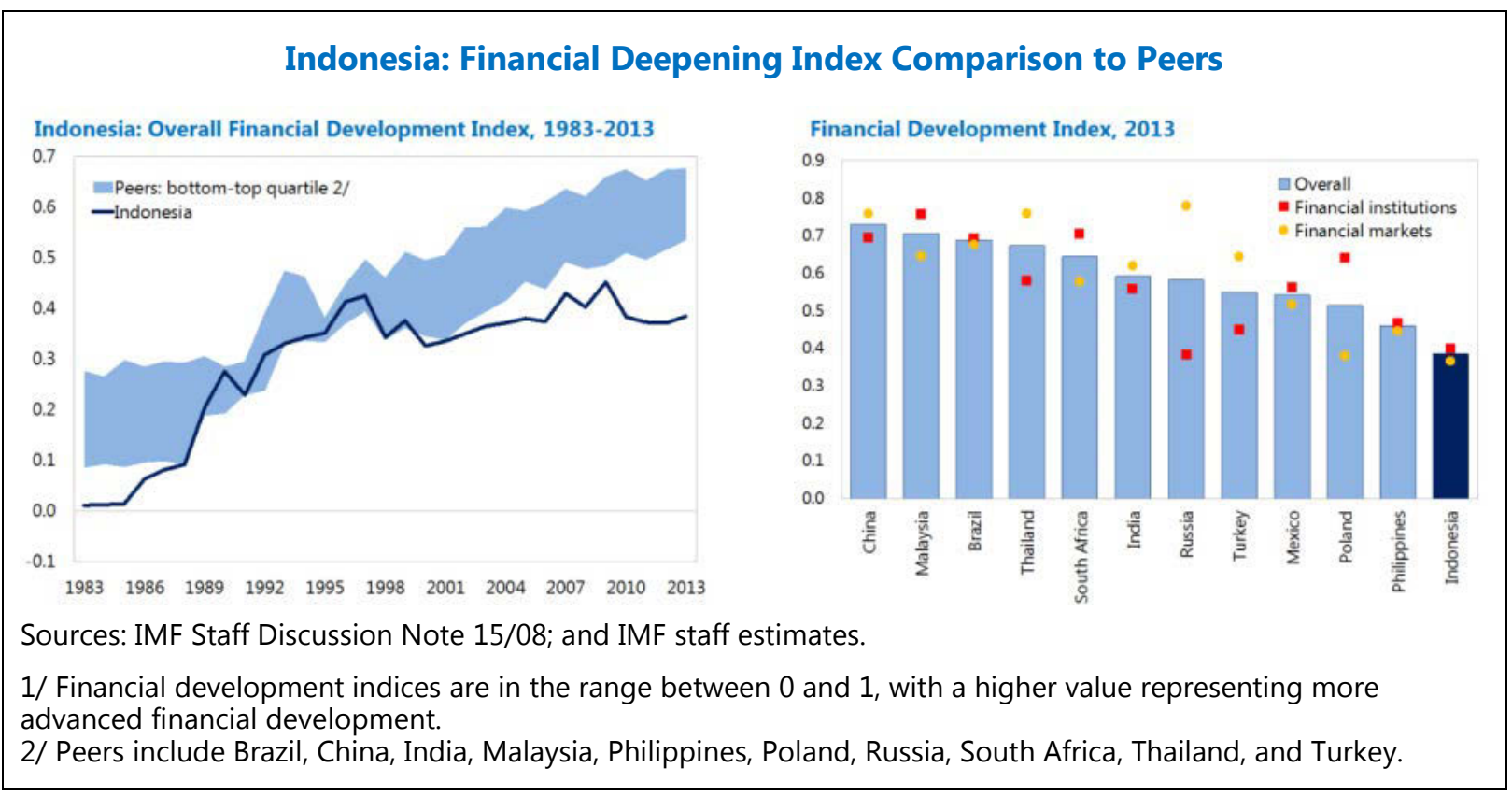

\section{Staff Position}

\section{Progress achieved in assessing financial and corporate sector vulnerabilities should}

continue. Macro-financial linkages should continue to be carefully monitored with regards to banks' soundness and liquidity, and corporates' NPLs and developments in FX debt, including conglomerates. The authorities should continue to ensure the full implementation of the corporate FX hedging regulations and proper loan classification and provisioning against problem loans.

Removing various bank deposit and lending rate caps would improve the financial sector's resilience to shocks and contribute to better transmission of monetary policy. ${ }^{12}$

41. The authorities are rightly focusing on making the FSCPM Law fully operational. The FSCPM Law establishes a coordination mechanism to maintain financial stability. The approval of this law should be followed by the closely coordinated revisions of the laws of BI, OJK, and LPS to ensure

\footnotetext{
12 Current supervisory guidance includes on deposit rate caps for large banks, informal guidance for single-digit lending rates, and maximum interest rates allowed for guaranteed deposits.
} 
the overall consistency of the legal framework, providing clarity on mandates and policy responsibilities.

42. Financial deepening should continue to be balanced with financial stability. This requires continuing to develop a strong supervisory and regulatory framework, as well as modernizing instruments and institutions. Progress on developing a national plan for financial deepening should continue to allow for enhanced coordination at the national level.

\section{Authorities' Views}

43. The authorities broadly shared staff's assessments and recommendations, and emphasized progress on the financial stability framework. They emphasized that the banking system is among the most capitalized and profitable in EMs, which provides strong buffers to support financial stability. While banks' asset quality has weakened somewhat from very low levels, banks are adjusting well including by increasing provisions and loan write-offs. The authorities are closely monitoring the process of NPL restructuring to ensure financial stability. The authorities also noted ongoing efforts to further improve monitoring of the corporate sector, where they see that risks have abated to some extent and remain manageable, aided by $\mathrm{BI}^{\prime} \mathrm{s} \mathrm{FX}$ hedging regulations. Finally, the authorities noted that the financial stability architecture had been strengthened and that the new FSCPM Law is expected to be fully operational in the coming months.

\section{Structural Reforms-Boosting Private Investment}

44. The authorities place high importance on revamping the business climate and have achieved some early successes. Following the landmark 2015 fuel subsidy reform, the authorities have been implementing reforms aimed at improving the business environment and strengthening the economy's productivity and competitiveness. The government announced 14 economic policy packages since September 2015, including some that streamline regulations and support private sector investment. The Foreign Direct Investment (FDI) regime was also partially liberalized, and clarity has increased on the setting of the minimum wage. ${ }^{13}$ These actions contributed to Indonesia's notable improvement in World Bank's Doing Business ranking in 2016 (15 positions to the $91^{\text {st }}$ position).

\section{Notwithstanding reforms to date, challenges remain to support private investment}

(Box 4). While the global economy has seen a slowdown in private investment in recent years, Indonesia has undergone a sharper decline than most of its regional peers, adversely affected by a slump in commodity prices. ${ }^{14}$ Investment growth in the commodity sector has stalled, while that in manufacturing has contracted, and the economy's linkages with global value chains have weakened.

\footnotetext{
${ }^{13}$ In 2015, a minimum wage formula for provinces was established, which is defined as Minimum Wage $t_{t+1}=$ Minimum Wage ${ }_{t} \times\left(1+\right.$ National Inflation Rate $_{t}+$ National GDP Growth Rate $\left._{t}\right)$

${ }^{14}$ For further information, see the accompanying selected issues on "Drivers for Private investment in Indonesia."
} 
Infrastructure is below those of other EM peers. Labor skills gap may have constrained investment, while rigid labor markets have resulted in a proliferation of short-term contracts.
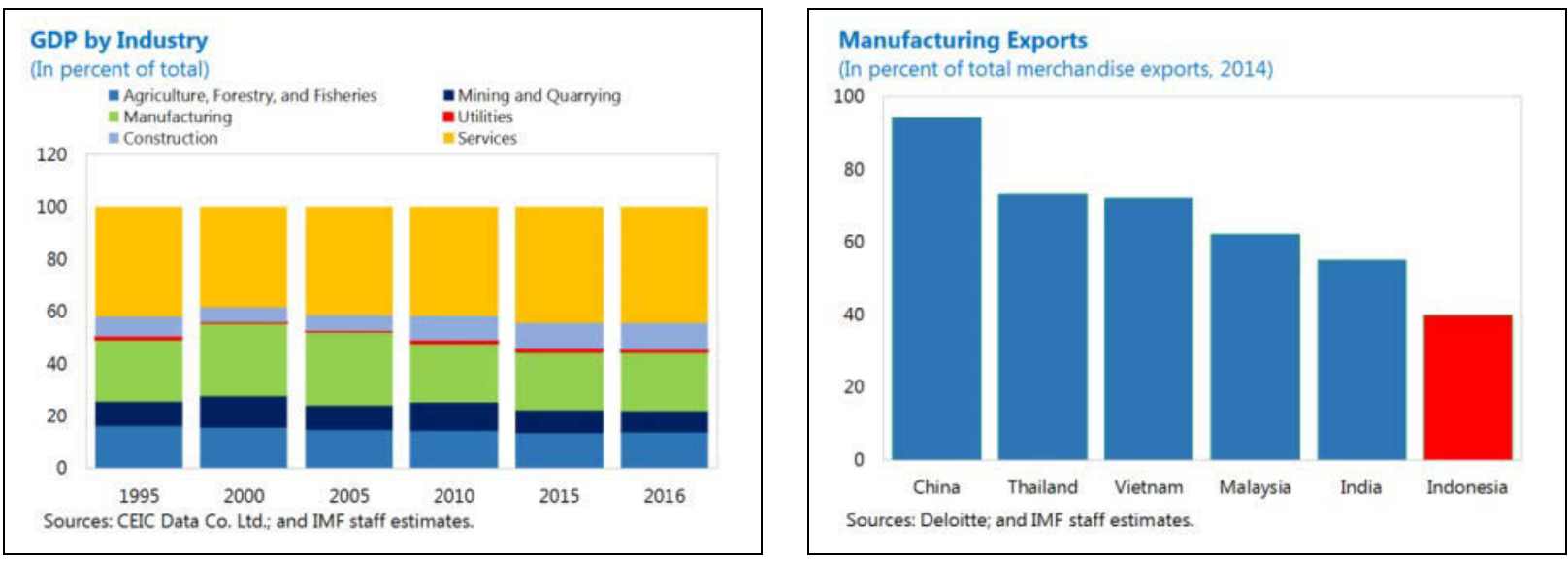

\section{Staff Position}

46. The government should continue with its efforts to strengthen the economy's productivity and competitiveness through targeted reforms. Building on these efforts, deeper reforms would bolster private investment and growth.

- Expanding infrastructure. Accelerated infrastructure development would reduce logistics costs and improve competitiveness and productivity, including in manufacturing and tourism. The authorities are rightly planning to expand PPP projects, and the recent start of construction of a large electricity generation plant under this scheme, expected to be completed by early 2020, is promising. Continuing financial deepening with stronger institutional investors base will help channel funds to infrastructure development.

- Policy packages reflect the authorities' commitment to improving the investment climate, and efforts should continue. Stronger inter-agency coordination is needed to accelerate the land acquisition process, streamline still-complex regulations, and reduce uncertainty on regulatory consistency. Increased coordination with local governments would improve the investment climate. A comprehensive review of the role of SOEs in the economy, with a view of establishing a level playing field and opening sectors to private investment, would also contribute to higher private investment and growth.

- Pursuing trade integration and further modernizing the FDI regime would promote investment and economic diversification. The recent revision in the FDI regime is an important step, but further liberalization will help attract FDI inflows as Indonesia's regulations remain comparatively restrictive. Opening up new sectors of the economy to private investment, including the energy and service sectors (e.g., tourism), could become important drivers of growth and diversification. Participation in new regional trade arrangements would help reinforce Indonesia's attractiveness and integration into global value chains, which should be pursued along with policies to mitigate the social impact of greater integration. 
- Stronger efforts are needed to improve the labor market and narrow the skills gaps. While the implementation of the minimum wage formula will increase business certainty, wage growth should be aligned with productivity growth at the enterprise or industry levels. Rigid labor practices, especially on worker dismissal procedures, should be rationalized and the social safety net strengthened to facilitate the transition. The skills gap would narrow with expanded vocational training linked to the economy's needs and improved quality of education, supported by more qualified teachers. Adopting a more open immigration policy toward skilled workers can temporarily abate the unmet demand for skilled workers.

\section{Authorities' Views}

47. The authorities reiterated a strong commitment to continuing structural reforms. They highlighted significant advance in setting the tone for the importance of structural reforms in Indonesia, and progress has been made through the economic policy packages launched since September 2015. They noted that structural reforms are key to strengthen the productivity and competitiveness of the economy and the need to differentiate Indonesia from peers. While continuing infrastructure development, they will further streamline regulations including the Negative Investment List (DNI) and at the local level, thereby bringing in FDI and diversifying growth engines, especially in manufacturing and tourism. They plan to review the role of SOEs, with a view to making more space for the private sector and its investment. The authorities also plan to reform vocational training and the quality of education in order to enhance manpower.

\section{STAFF APPRAISAL}

48. The Indonesian economy continues to perform well, supported by robust growth and macroeconomic stability. Over the past few years, the economy has weathered well a major commodity down-cycle and several episodes of financial turbulence affecting EMs, aided by a prudent mix of macroeconomic policies and structural reforms. The near-term macroeconomic outlook remains positive, with economic growth rising modestly, inflation within the official target band, and the current account deficit manageable.

49. Downside risks to the outlook have risen recently and are largely external. Indonesia's reliance on external financing leaves it susceptible to global shocks and funding reversals. External risks include uncertainties around the policies of the incoming U.S. administration, tighter and more volatile global conditions, spillovers from a significant China slowdown, and lower commodity prices. Domestic risk arises primarily from tax revenue shortfalls and higher interest rates, which could curb fiscal space to support growth.

50. The authorities have strengthened the short-term fiscal framework. The revised financial plan approved by Cabinet for 2016 includes prudent revenue projections and spending commitments. While Indonesia has some fiscal space to expand spending, the decision to rebuild buffers by targeting a lower fiscal deficit in the budget for 2017 is appropriate. Progress continues to be made in reforming and better targeting subsidies and improving the efficiency of spending. 
51. There is room to strengthen the medium-term fiscal framework, including through fiscal reforms that generate productivity gains and improved infrastructure. Low tax collections continue to limit fiscal space. The authorities' plan to upgrade the main tax laws in 2017 is well placed. There is also room to deepen tax administration reforms to strengthen compliance and reduce compliance costs. Ongoing actions to enhance the quality and efficiency of public spending should continue. The authorities should continue to move towards automaticity of energy prices via a transparent fuel pricing mechanism. The domestic investor base of the government bond market needs to be strengthened, which combined with higher domestic revenue mobilization, will gradually reduce reliance on external financing over the medium term.

52. Tax reform can generate the bulk of additional needed tax revenue. Excise tax rates on vehicle and tobacco could be increased in the near term, together with a new environmental (fuel) tax, while simplifying the structure of tobacco excises over the medium term. VAT provides the greatest revenue potential and the authorities could gradually raise the VAT rate, coupled with removing VAT exemptions, while simplifying administration. PIT base could be broadened by a lower threshold for the top rate, while capitalizing on asset declarations under the amnesty.

53. Business-friendly tax administration reforms would lower taxpayers' compliance costs. The business environment can be strengthened by removing ambiguities and inconsistencies in the tax laws, and simplifying VAT filing and refund requirements. Tax collection efficiency can be improved by enhanced risk management, extended audit coverage through more specific-issue audits, use of external taxpayer information, and moving the Extensification program towards a more targeted campaign.

54. The current stance of monetary policy is appropriate. Policy rates were lowered in 2016, in an environment of falling inflation and reduced external pressures on the rupiah. With inflation remaining within the target band and the external environment more uncertain, the policy rate since has been placed on hold. Exchange rate flexibility has allowed the economy to adjust to intermittent shocks, including higher volatility in capital flows. Continuing with this approach will be critical to allow the economy to adjust to shocks, including by standing ready to adjust the monetary policy stance in the event of severe external pressures and allowing the exchange rate and bond yields to move flexibly. Indonesia's external position in 2016 is assessed to continue to be broadly consistent with medium-term fundamentals and desirable policy settings.

55. The reform of monetary operations should continue. The introduction of the 7-day reverse repo rate as the policy rate has been smooth, with early indications that it has improved the transmission of monetary policy. The authorities also announced the introduction of reserve requirement averaging, which is expected to improve banks' liquidity management. Removing various bank deposit and lending rate caps would improve financial sector resilience to shocks and improve the transmission of monetary policy.

56. Risks from the corporate sector have moderated slightly but remain elevated. The corporate sector remains vulnerable due to FX debt exposure, an elevated share of distressed debt, and reduced cash buffers. FX risk of corporate debt has mitigated somewhat as a result of lower 
external borrowing and deleveraging, supported by the BI regulation on FX hedging. In addition, a large portion of the external debt of nonfinancial corporates is with parent or related loans.

Corporate performance varies across sectors, with manufacturing particularly weak. Profitability has also improved somewhat, supported by cost-cutting and postponement of investment projects. In response to expectations for higher interest rates following the U.S. elections and the increase in the U.S. policy rate in December, corporates could face higher funding costs together with exchange rate depreciation and less supportive capital flows. In this context, the continued full implementation of the hedging regulation is important to contain risks, while the preparation and implementation of a balanced financial deepening plan can gradually reduce corporates' reliance on external financing.

57. The banking system overall remains sound, with some pockets of vulnerabilities. Some smaller banks are more vulnerable to liquidity shock due to their higher reliance on short-term time deposits. Other sources of vulnerabilities are increased NPLs, special mention loans (SMLs), and restructured loans, although there are early signs that they are stabilizing. The authorities should continue to closely monitor banks' soundness and liquidity conditions, including loan classification and provisioning, while enhancing inter-agency coordination. Macro-financial linkages should continue to be carefully monitored with regards to corporate sector performance, particularly NPLs and developments in FX debt.

58. Making the FSCPM Law fully operational is a priority. Issuing the relevant implementing regulations should be followed by the coordinated revisions of the laws of BI, LPS, and OJK, to ensure the overall consistency of the legal framework to the new institutional landscape. These revisions should provide clarity on the mandates and policy responsibilities of each institution.

\section{Deepening structural reforms would bolster growth and diversify the economy. While} consumption-driven growth can be sustained in the medium-term, boosting growth and making it more inclusive will require further structural reforms to improve the business environment and boost private investment. Priorities include expanding infrastructure, enhancing the regulatory framework, especially of local governments, opening new sectors of the economy to investment, and closing labor skill gaps through improved education and a more flexible immigration regime for skilled workers.

60. It is recommended that the next Article IV consultation take place on the standard 12-month cycle. 


\section{Box 1. Indonesia: External Sector Assessment ${ }^{1}$}

Overall Assessment. In 2016, Indonesia's external position is assessed to be broadly consistent with medium-term fundamentals and desirable policy settings. Lower commodity prices and weak trading partner demand for commodity exports have been broadly compensated by import compression. Easing trade and investment restrictions, growthfriendly revenue mobilization, deepening financial markets, and improving labor markets would help strengthen overall competitiveness over the medium term. External financing appears sustainable, but could be affected by domestic or external shocks. The authorities' handling of capital outflows in the recent period has been broadly consistent with the Fund's Institutional View on capital flows.

Foreign asset and liability position and trajectory. At end-June 2016, Indonesia's net international investment position (NIIP) stood at -46 percent of GDP, compared to $-431 / 4$ percent of GDP at end-2015. A majority of the widening in the first half of 2016 was due to strong net portfolio inflows (mainly government debt). At end-June 2016, gross external liabilities stood at 71 percent of GDP. At end-September 2016, Indonesia's gross external debt was moderate at $353 / 4$ percent of GDP, with about $61 / 2$ percent of GDP denominated in rupiah. The level and composition of the NIIP and gross external debt indicate that Indonesia's external position is sustainable, but nonresident holdings of rupiah denominated government bonds, with a share of 37 percent at end-November 2016, could be affected by global volatility. Private external debt growth is expected to slow on the implementation of BI's FX hedging regulations, and expected tightening of global financial conditions.

Current account. Drawing on the IMF's model-based External Balance Assessment (EBA) regression exercise, staff assess the cyclically-adjusted current gap to be -0.8 percent to 1.2 percent of GDP relative to the level consistent with medium-term fundamentals and desirable policies for 2016. Much of this gap could be accounted for by low public health spending in Indonesia and fiscal policy gaps in other countries.

Real exchange rate. Compared to the 2015 average, the REER appreciated by 3.1 percent in the first ten months of 2016. EBA index and level REER results suggest the REER gap to be about -3.4 percent to 3.2 percent, respectively, in line with staff's REER gap assessment in the range of -6 percent to 4 percent based on the CA assessment.

\begin{tabular}{|lc|}
\hline \multicolumn{2}{|c|}{$\begin{array}{c}\text { Indonesia: Estimated Policy Contributions } \\
\text { to Current Account Gap, 2016 } \\
\text { (In percent of GDP) }\end{array}$} \\
\hline Actual CA & -2.0 \\
Cyclically-adjusted CA & -1.4 \\
CA norm & -0.6 to -2.6 \\
Estimated CA gap & -0.8 to 1.2 \\
Of which: & 1.0 \\
$\quad$ Partners' fiscal deficits & 0.5 \\
Domestic public health spending & -2.0 \\
$\quad$ Residual & -3.4 and 3.2 percent \\
EBA REER index and level gaps 1/ & -6 to 4 percent \\
Staff-assessed CA REER gap 1/ & \\
\hline 1/ Negative value implies REER is below levels consistent with \\
fundamentals and desirable policies.
\end{tabular}

Capital and financial accounts. Indonesia's gross external financing requirement is expected to be about 9.2 percent of GDP in 2016, with amortization at about 6 percent of GDP. Net FDI and new borrowing are projected at 1.5 percent and 7.6 percent of GDP, respectively. Net and gross financial flows have been steady since the global financial crisis despite some short episodes of volatility. The narrower current account deficit and strengthened policy framework including exchange rate flexibility since mid-2013 have also helped reduce capital flow volatility. For 2016, financial flows have been supported by attractive bond yields and assets repatriation related to the tax amnesty but could become weaker or reverse in the event of large domestic or external shocks as seen in November. Continued strong policies focused on strengthening the fiscal position, keeping inflation in check, and easing supply bottlenecks would help sustain capital inflows in the medium term.

FX intervention and reserves levels. Indonesia's floating regime has facilitated adjustments in exchange rates to market conditions. Reserves are assessed to be adequate as assessed against the IMF's composite reserve adequacy metric, sufficient to absorb most shocks, with predetermined drains also manageable. Intervention should aim primarily at preventing disorderly market conditions, while allowing the exchange rate to adjust to external shocks.

1/ For more details, see Appendix II. 


\section{Box 2. Indonesia: Monetary Operation Reforms}

Backdrop for reforms. Since 2010, the transmission of the policy rate had weakened, as the overnight (O/N) interbank interest rate hovered near the floor of the interest rate corridor represented by Bank Indonesia's deposit facility rate (as a Standing Facility), reflecting ample liquidity arising from large capital inflows. This opened up a divergence of as much as 200 basis points between $\mathrm{O} / \mathrm{N}$ interbank rates and the stated policy rate. Without a transacted anchor at the short-end of the yield curve, the interbank money market has also failed to develop a viable interest rate structure, notably for tenors of 3 months to 12 months.

Bank Indonesia has launched a series of reforms to improve the transmission of monetary policy operations, including:

- $\quad$ Shifting the policy rate to the BI 7-day reverse repo rate, a risk free rate actually transacted by the $\mathrm{BI}$ with the money market. The shift did not change the monetary policy stance.

- Narrowing the interest rate corridor between the overnight Lending Facility and Deposit Facility, reverting to a mid-corridor system at \pm 75 bps around the new policy rate.

- Managing the transition well, ably communicating to the markets. During the period, BI absorbed more liquidity at the longer tenors of the term structure, helping keep excess liquidity in the overnight deposit facility contained, and implemented measures to strengthen the interbank rate mechanism (JIBOR). To further sensitize market participants to the impending shift, BI published the term structure of its monetary operations (up to one year) in its monetary policy statements since May 2016, to provide a reliable rate structure for market reference.

- Announcing reserve requirement averaging. In November 2016, BI indicated that it was preparing for implementation of a reserve requirement averaging scheme in the second half of 2017, which would further incentivize banks' liquidity management and strengthen policy transmission.

Further reforms are recommended to strengthen transmission and deepen the money markets:

- Shifting from fixed-rate to variable-rate auctions, for the 3 to 12 month tenors, to encourage market participants to transact for price discovery and shape the yield curve.

- Removing transmission constraints to deposit rates, notably ceilings for large banks and maximum guaranteed deposit rates.

- Completing the short-term risk-free yield curve by gradually expanding issuance of short-tenor treasury bills as instruments to underpin interbank money market transactions, including repos. 
Box 3. Indonesia: Update on Balance Sheet Analysis (BSA) ${ }^{1}$

The pattern of intersectoral funding and exposures is broadly unchanged between end-2014 and end-2015. Nonfinancial corporations (NFCs) borrowing from the rest of the world (ROW), in the form of both FDI and otherwise, remains the largest exposure in the BSA. The rupiah depreciated approximately 10 percent in U.S. dollar terms as of mid-2016, which inflates all BSA positions denominated in foreign currency proportionately. After correcting for this development, NFC borrowing from the ROW has significantly decreased by 20 percent. The largest change in exposure stems from a 30 percent increase of government borrowing from the ROW.

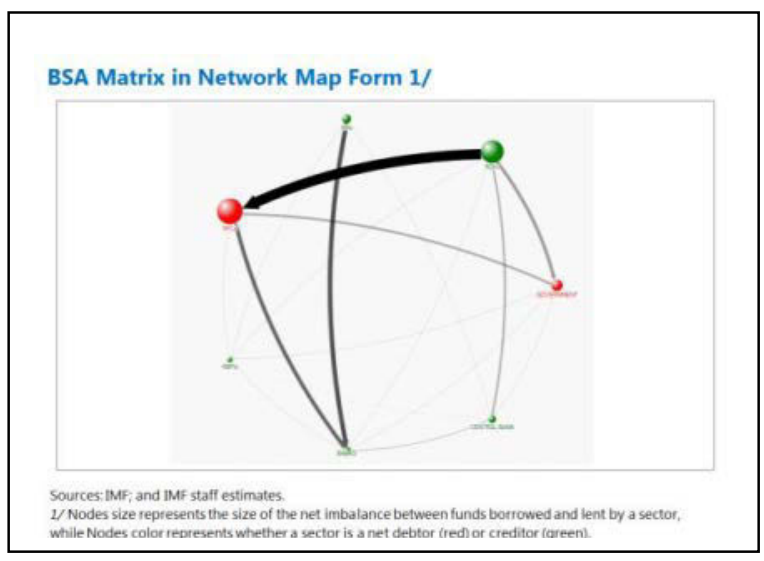

\section{Stress-testing demonstrates the impact of a} combined depreciation ( 25 percent) and capital outflow shock (10 percent). ${ }^{2}$ In this scenario, NFCs lose 10 percent of their funding from the ROW, while existing liabilities increase by 25 percent in national currency terms. In a second round, NFCs replace the missing funding with bank funding (or deposit withdrawal), thereby passing on the shock to the banking system. After the shock, liabilities of NFCs with both ROW and banks increase by about 4 percent. The shock also affects government debt

\begin{tabular}{|cccc|}
\hline \multicolumn{4}{|c|}{$\begin{array}{l}\text { Decomposition of Change in Outstanding NFC } \\
\text { Borrowing from ROW During } 2015 \\
\text { (In trillions of rupiah) }\end{array}$} \\
\hline $\begin{array}{c}\text { Opening } \\
\text { Balance }\end{array}$ & FX Impact & $\begin{array}{c}\text { Corrected } \\
\text { Change }\end{array}$ & $\begin{array}{c}\text { Closing } \\
\text { Balance }\end{array}$ \\
\hline 4,326 & 552 & -932 & 3,946 \\
& $13 \%$ & $-22 \%$ & $-9 \%$ \\
\hline
\end{tabular}
which increases by 4 percent of GDP.

\begin{tabular}{|c|c|c|c|c|c|c|c|}
\hline \multicolumn{8}{|c|}{$\begin{array}{l}\text { Difference of Intersectoral Net Positions } \\
\text { (In percent of GDP, after combined shock) }\end{array}$} \\
\hline & Government & Central Bank & Banks & NBFIs & NFCs & $\mathrm{HHs}$ & ROW \\
\hline Government & & $-0.12 \%$ & $0.19 \%$ & $0.00 \%$ & $0.00 \%$ & $0.00 \%$ & $4.34 \%$ \\
\hline Central bank & $0.12 \%$ & & $0.57 \%$ & $0.00 \%$ & $0.00 \%$ & $0.00 \%$ & $-3.08 \%$ \\
\hline Banks & $-0.19 \%$ & $-0.57 \%$ & & $0.00 \%$ & $-4.78 \%$ & $0.41 \%$ & $0.46 \%$ \\
\hline NBFIs & $0.00 \%$ & $0.00 \%$ & $0.00 \%$ & & $-0.19 \%$ & $0.00 \%$ & $0.17 \%$ \\
\hline NFCs & $0.00 \%$ & $0.00 \%$ & $4.78 \%$ & $0.19 \%$ & & & $4.07 \%$ \\
\hline $\mathrm{HHs}$ & $0.00 \%$ & $0.00 \%$ & $-0.41 \%$ & $0.00 \%$ & & & $0.00 \%$ \\
\hline ROW & $-4.34 \%$ & $3.08 \%$ & $-0.46 \%$ & $-0.17 \%$ & $-4.07 \%$ & $0.00 \%$ & \\
\hline
\end{tabular}

Sources: IMF; and IMF staff estimates.

1/ Prepared by Elena Loukoianova and Giovanni Ugazio (STA).

2/ See https://www.imf.org/external/pubs/ft/scr/2016/cr1682.pdf for methodology and discussion. 


\section{Box 4. Private Investment in Indonesia}

Indonesia has seen a marked slowdown in private investment. While investment globally and in the region has decelerated, Indonesia's investment has slowed more markedly than that of peers. Over the past several years, investment has become more important in Indonesia as a source of growth, accounting for a third of economic output. The investment slowdown mainly reflects weak private investment, in contrast with a pickup in public investment.

\section{Cyclical factors related to both the commodity down-cycle and subsequent economic downturn have} hampered private investment. After a commodity-related investment boom prior to 2013, commodity prices have slumped, pushing down investment growth. The subsequent economic slowdown affected sectors beyond commodities, notably manufacturing. Capacity utilization in mining and manufacturing also fell and remains subdued, accompanied by a sharp fall in selling prices. With cash flows decreasing, corporates responded by cutting costs, postponing investment and laying off workers. Since a number of corporates still rely on internal cash flows for funding, a prolonged weakness in commodity prices and soft economic growth has reduced financing capacity for investment.

\section{Structural constraints have also affected private investment, resulting in weakened linkages with global} value chains. Investment has been constrained by weak infrastructure, rigid labor markets and labor skills gaps, as well as regulatory risk and uncertainty. Also financial constraints have been a factor, as some banks have tightened their lending standards amid higher NPLs. While the business climate has started to improve on the back of the authorities' reforms, important challenges remain.

\section{In contrast, public investment is rising, led by local governments and SOEs, with progress made in PPPs.}

- The central government is increasingly channeling investment through local governments and encouraging SOEs to ramp up capital spending. Capital expenditure of SOEs doubled in 2016, and are expected to rise by around 35 percent in 2017, aimed at meeting infrastructure development needs (text chart). To strengthen investment capacity, the government capitalized selected SOEs in the energy, food, and infrastructure sectors in 2016 (amounting to about 0.4 percent of GDP). In 2017, the government is planning to establish six holding companies in different sectors to increase their financial leverage and reduce duplication.

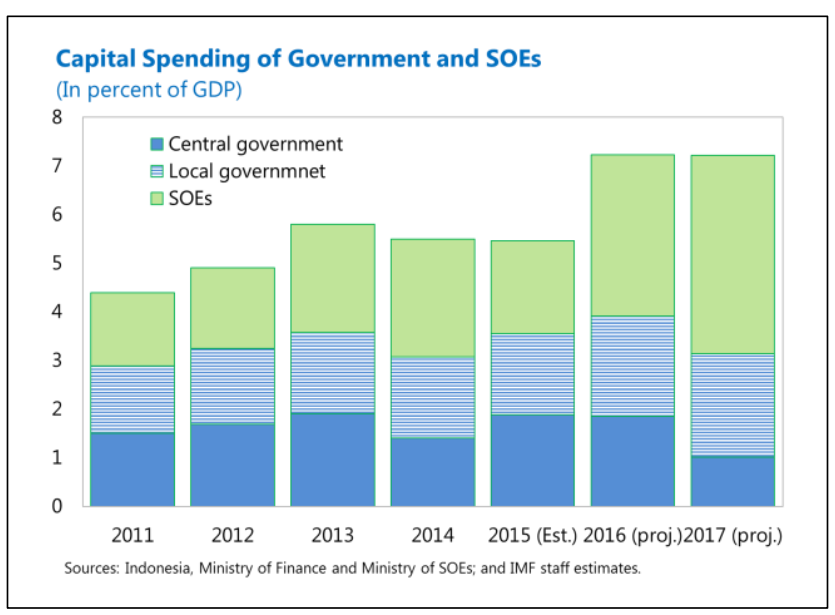

- The authorities have also made some recent progress with PPPs. Several projects have started, including the landmark project of $2 \mathrm{GW}$ Central Java Power Plant, with the investment amounting to 0.4 percent of GDP, partly funded by overseas investors. Considerations are also being given to diversifying funding sources, such as securitizing existing infrastructure and promoting SOE joint ventures with the private sector. The government also has increased the number of priority projects to 30 from 22 projects aimed to start by end-2018 (equivalent to 8 percent of GDP), where SOEs and PPPs are expected to play an important role. 


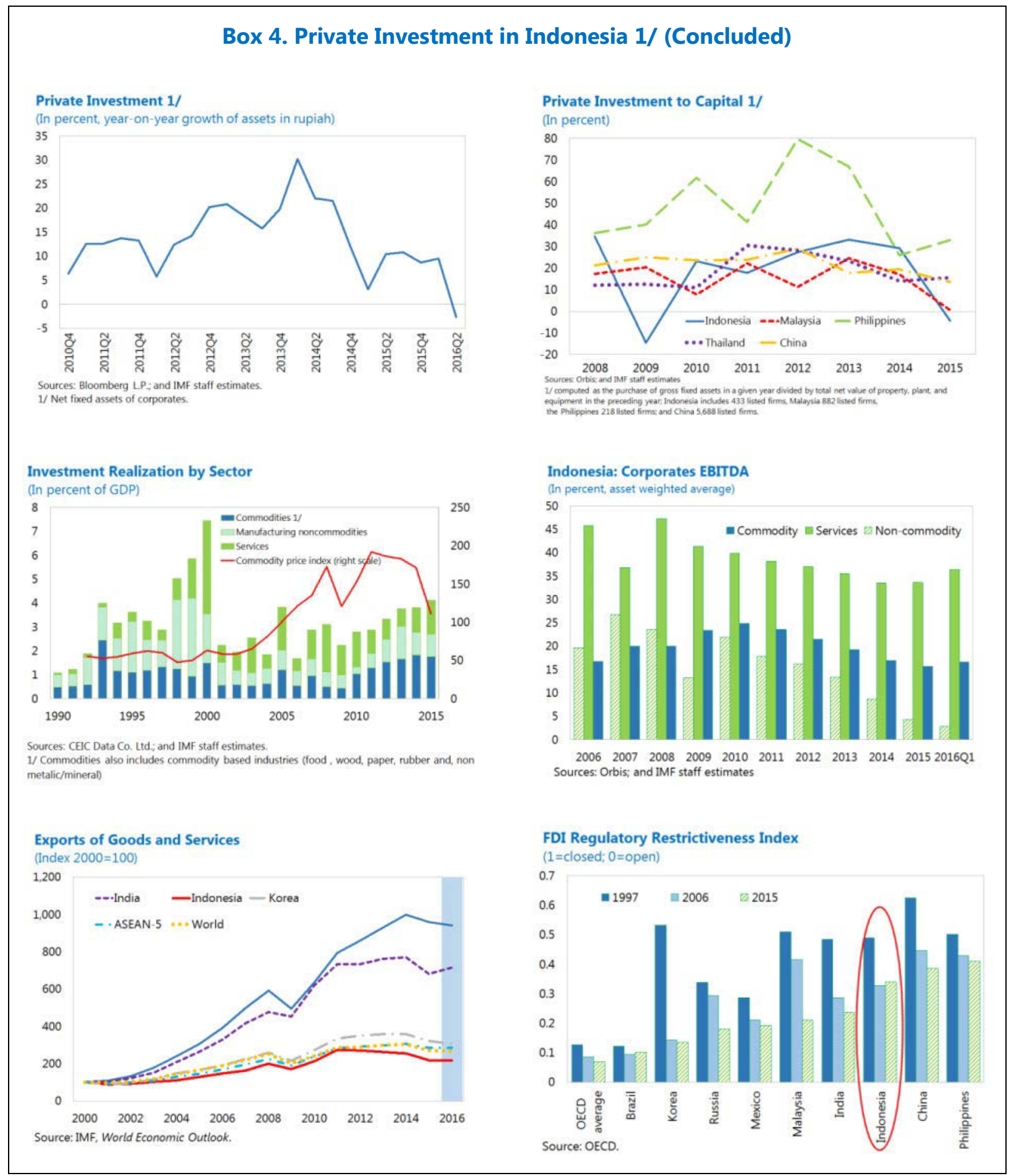




\section{Figure 2. Indonesia: Macro-Financial Developments}

Key commodity prices stabilized, after having declined since 2012.

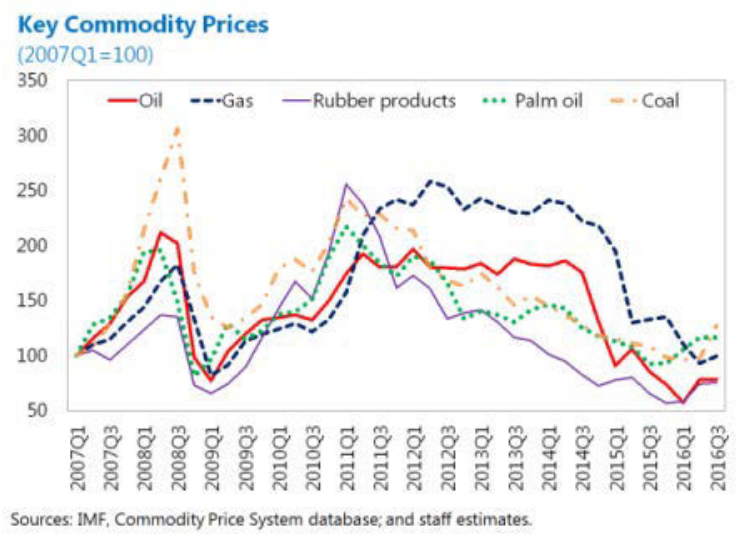

Economic growth has stabilized since 2015:Q3, after having slowed with a shrinking contribution of the commodity sector.

Commodity Share and Contribution to Real Growth

(In percent, year-on-year, seasonally adjusted)

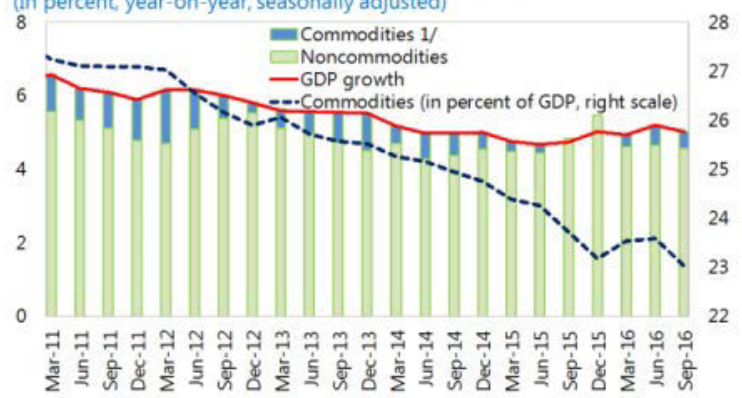

Sources: Haver Analytics; and IMF staff estimates.

$1 /$ Includes agriculture, mining and quarrying, manufacturing coal, petroleum and gas.

The corporate sector has been impacted by the commodity down cycle, with reduced cash flows and slowing investment.

Commodity Prices, Corporate Cash and Fixed Investment

(Index 2007:Q1=100)

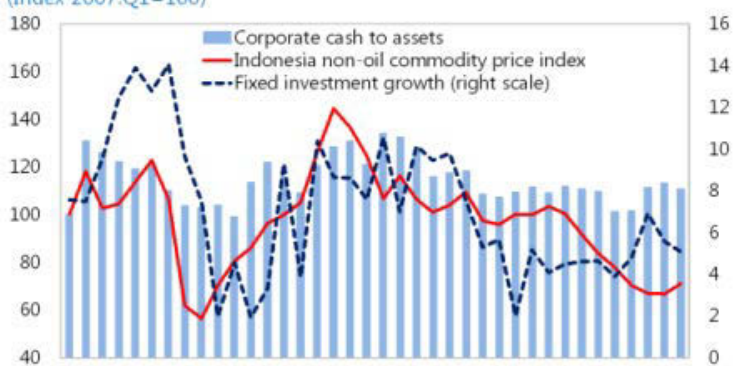

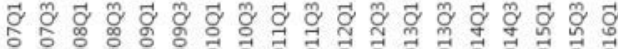

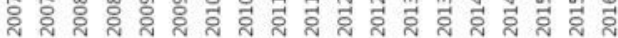

Sources: CEIC Data Co. Ltd, Bloomberg L.P.; and IMF staff estimates
The terms of trade rebounded, as Indonesia's export commodity prices picked up, notably coal and palm oil.

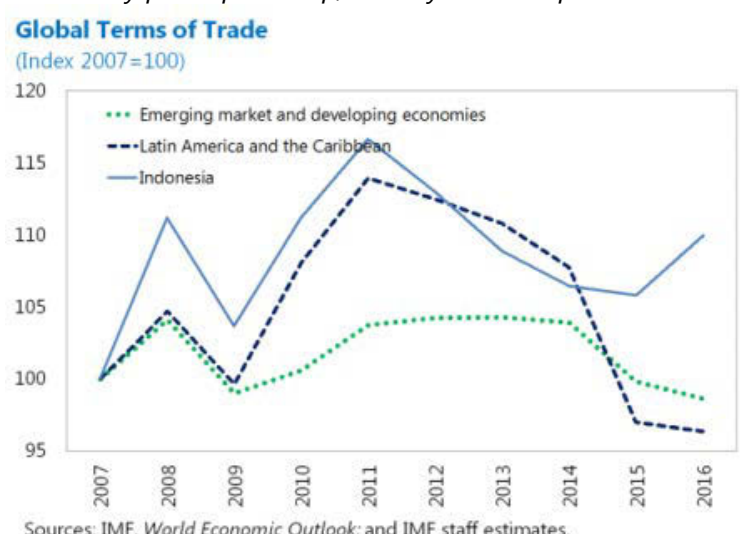

Falling commodity exports has been offset by a compression in imports.

External Developments

(In percent of GDP)

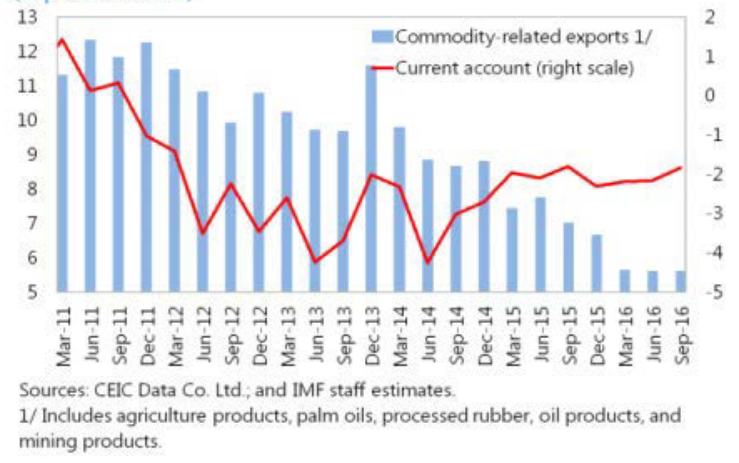

The commodity down-cycle also has led to a slowdown in loan growth, together with slowing deposit growth.

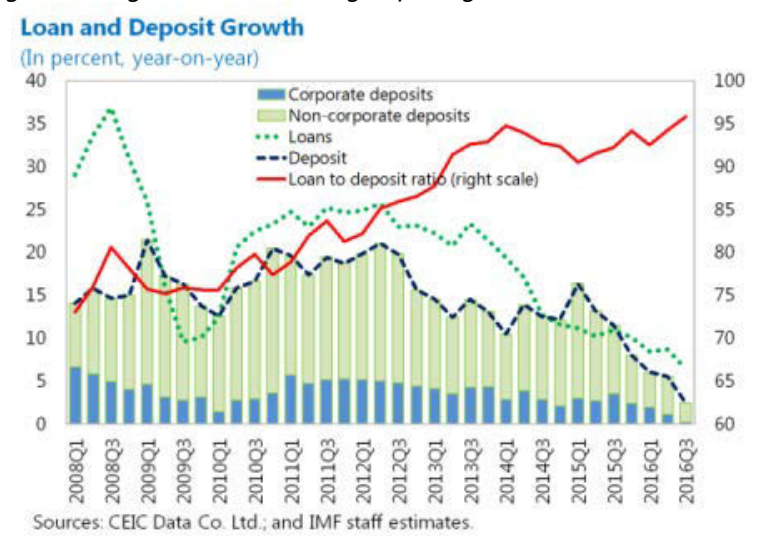




\section{Figure 2. Indonesia: Macro-Financial Developments (Concluded)}

Corporates' external borrowing has started to deleverage, after rising fast over the past few years,

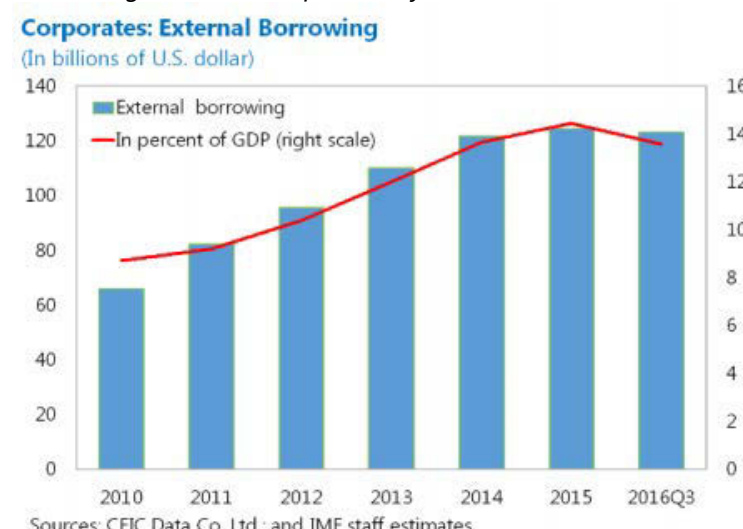

Monetary easing has been increasingly transmitted to lending rates, especially for corporate-related credit.

Commercial Banks' Lending Rates

Ig percent per annum, weighted average)

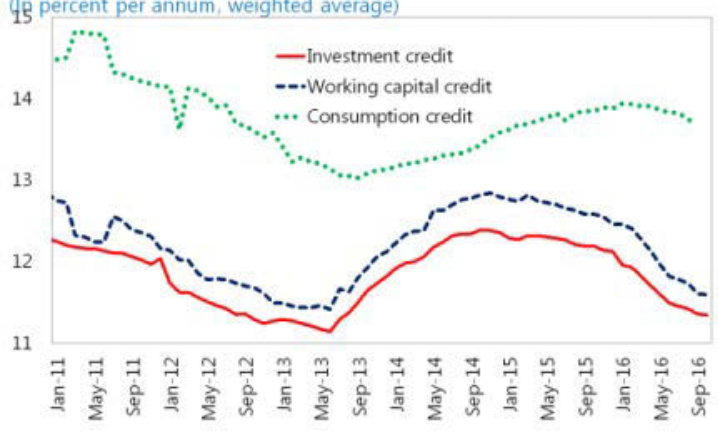

Source: CEIC Data Co. Ltd.

NPLs in the banking system have been creeping up, particularly in the manufacturing and mining sectors.

Commercial Bank Loan Quality

(In percent)

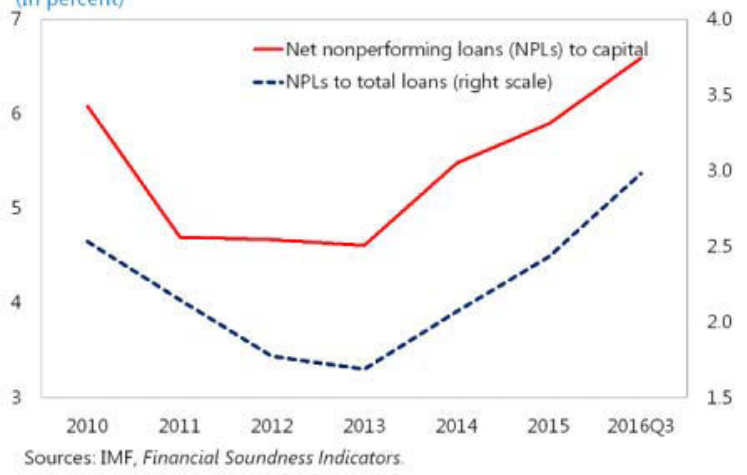

Corporate profitability has begun to recover recently, mainly reflecting cost-cutting efforts.

Profitability - Return on Assets of Listed Companies

(In percent)

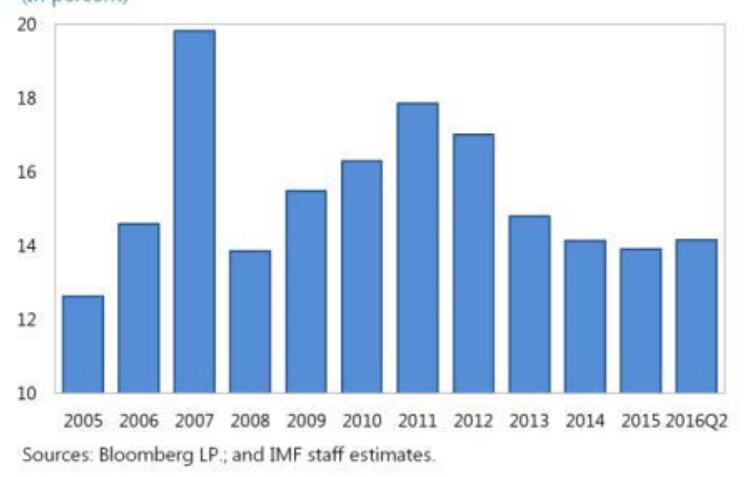

Property prices have been subdued, in tandem with slowing economic growth.

Property Prices

(Vear-on-year percent change)

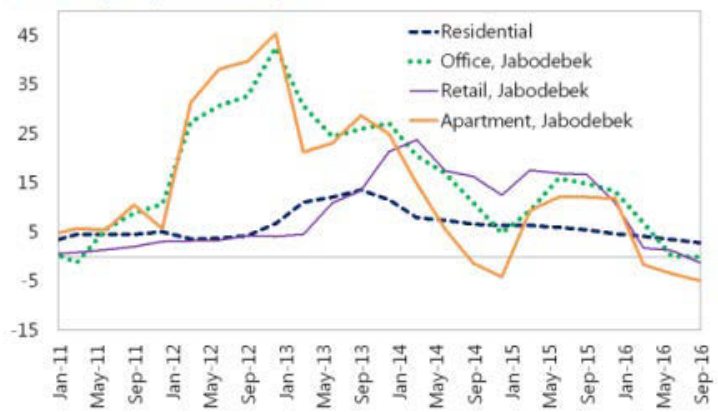

Source: Bank Indonesia, Commercial Property Survey.

On balance, macro-financial risks remain manageable, with higher risk appetite and spillover risks.

Indonesia: Financial Stability Map 1/ _ 2015Q3

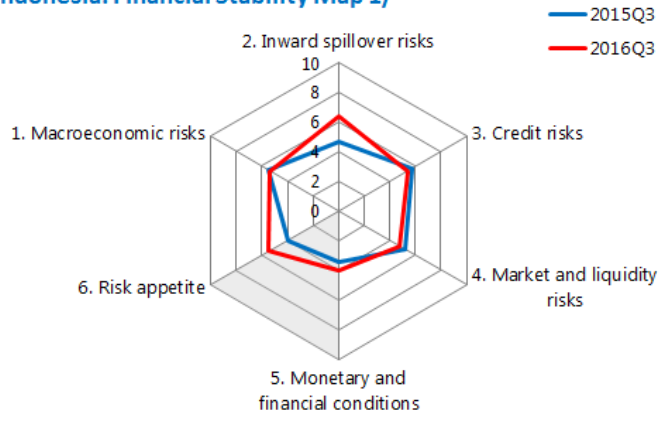

1/ Away from center signifies higher risks, easier monetary and financial conditions, or higher risk appetite. 
Figure 3. Indonesia: Recent Market Developments

Financial markets were buoyed in most of 2016, before undergoing some corrections following the U.S. election.

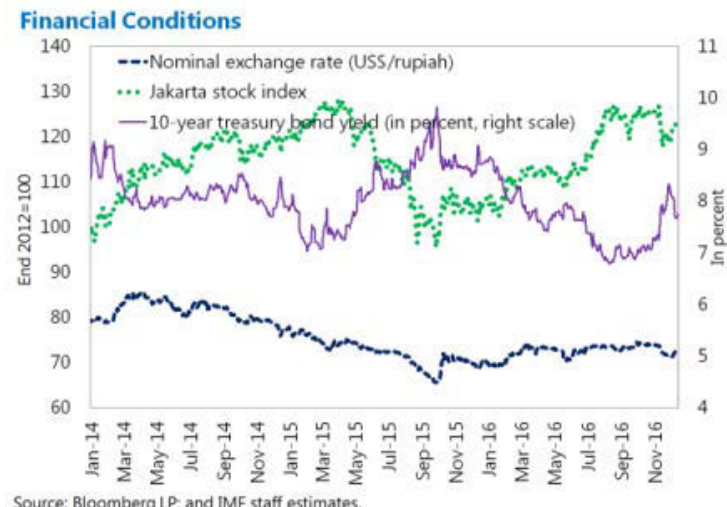

Source: Bloomberg LP; and IMF staff estimates.

After having depreciated since 2013, the rupiah has started to appreciate in 2016.

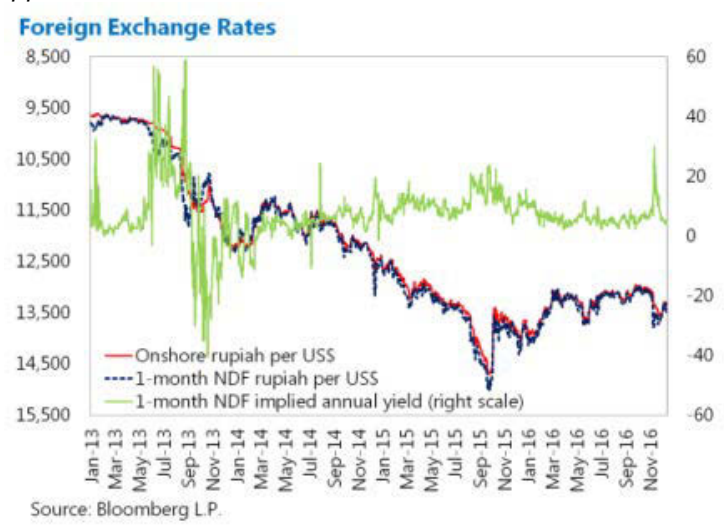

Domestic bond yields have declined significantly in most of 2016 before picking up recently...

Domestic Government Bond Yields

(In percent per annum)

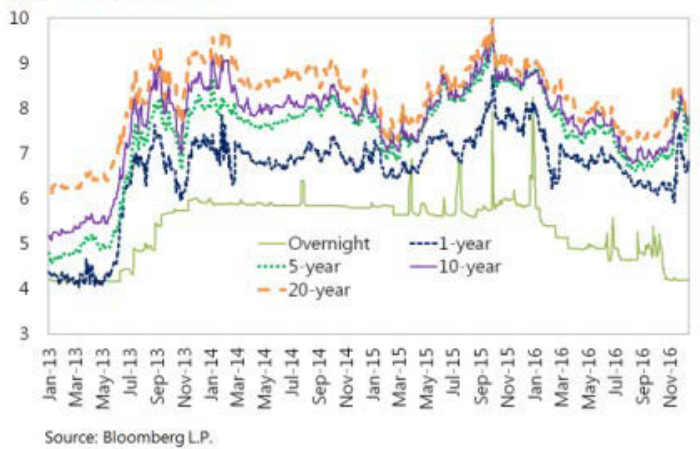

Portfolio inflows in 2016 were mostly supportive and currency volatility declined, although undergoing some reversals recently.

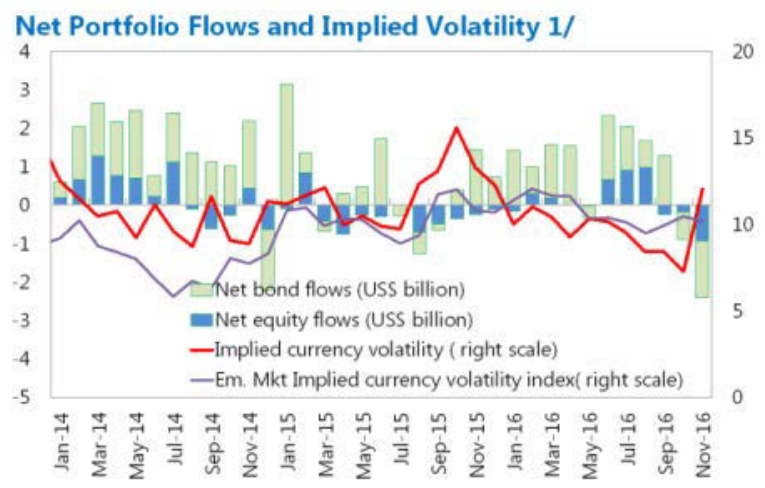

Sources: Bloomberg L.P; and IMF staff calculations

1/ High implied volatility indicates potential for large price swings in either direction.

...while equity prices have rallied this year until recently.

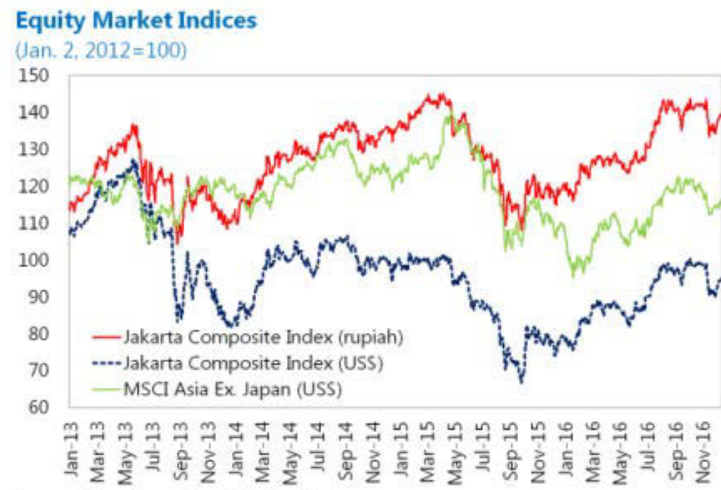

Sources: Bloomberg LP: and IMF staff estimates.

...driven by substantial presence of foreign investors in rupiah government bonds and, very recently, the U.S. election results.

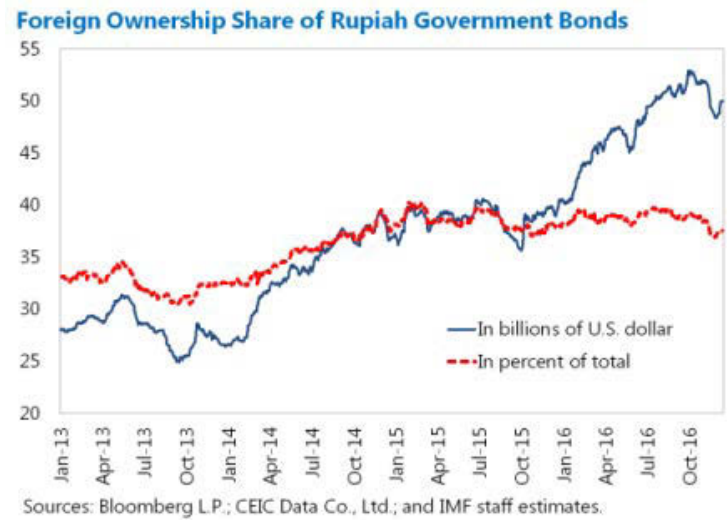




\section{Figure 4. Indonesia: Real Sector}

Growth remained robust in 2016:Q3 on private consumption, despite fiscal consolidation and weak private investment.

Contribution to Real GDP Growth

(In percent, year-on-year)

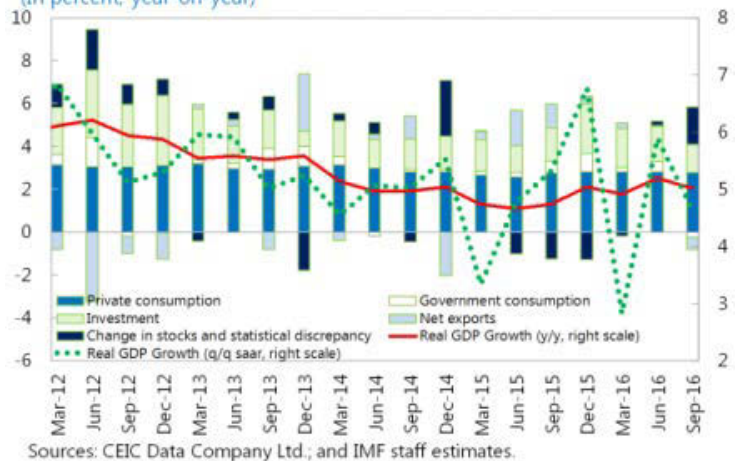

PMI and industrial production have gradually recovered, but remain weak...

Purchasing Managers' Index (PMI) and Industrial Production

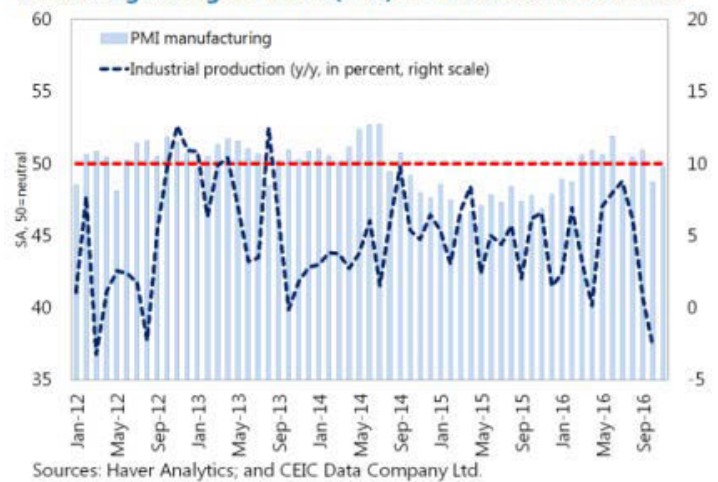

Capital goods imports have turned positive, reflecting the expansion of public investment.

Investment Activity Indicators

(In percent)

20 Cement sales (y/y, 3mma)

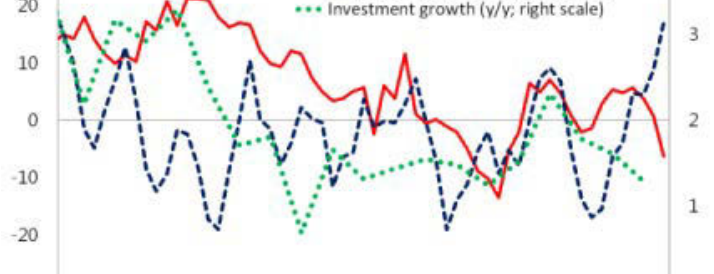

$-300$

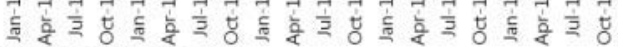

Source: CEC Data Company Ltd.
Declines in potential growth reflect lower capital input growth and TFP growth likely related to the commodity down-cycle.

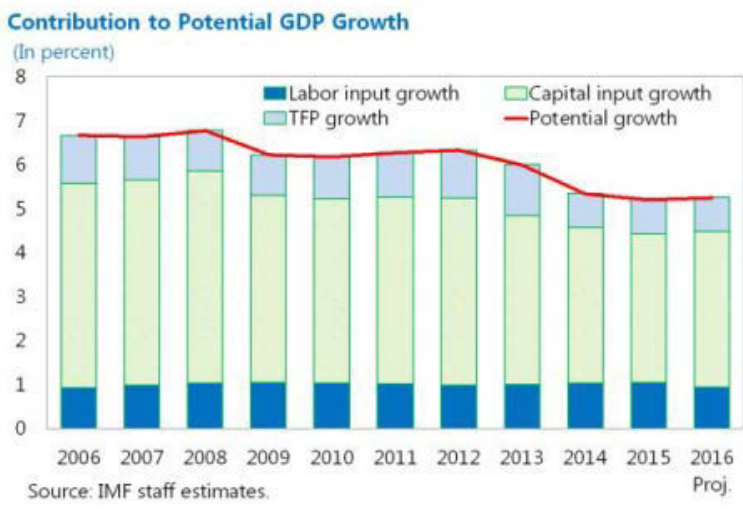

... and consumption indicators, notably vehicle sales, suggest a resilience in private consumption.

Retail and Transport Sales and Consumer Sentiment

(Year-on-year percent change)

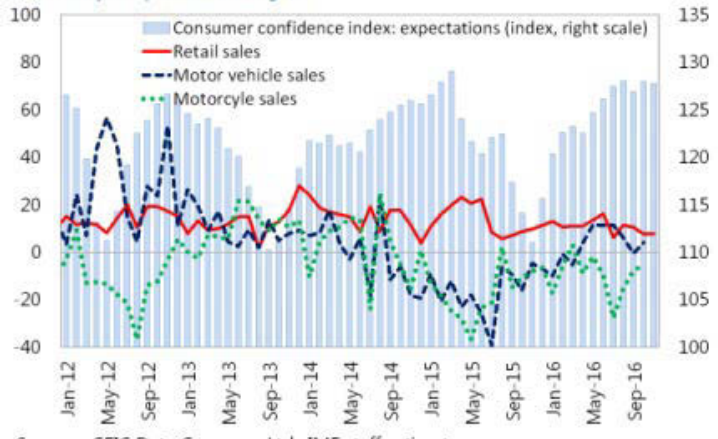

Sources: CEC Data Company Ltd; IMF staff estimates.

Inflation has fallen to the lower limit of BI's target band, on stable food and administered prices, and weak demand.

Inflation Developments

(In percentage points of headline inflation, unless othenwise indicated)

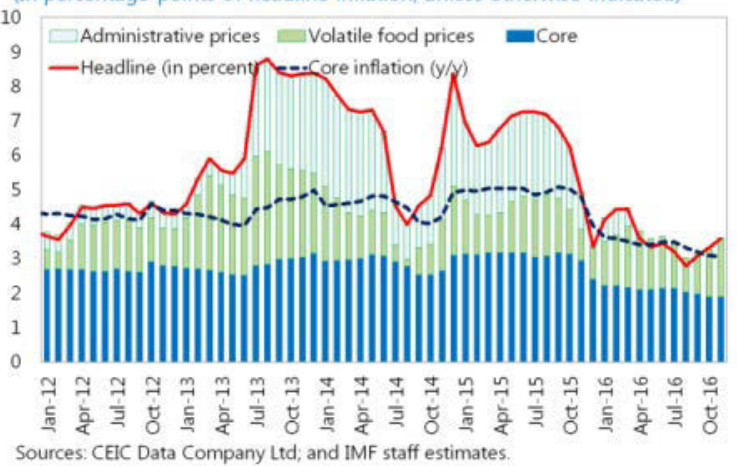




\section{Figure 5. Indonesia: External Sector}

Despite a decline in exports, the current account deficit has narrowed mainly on a compression in imports..

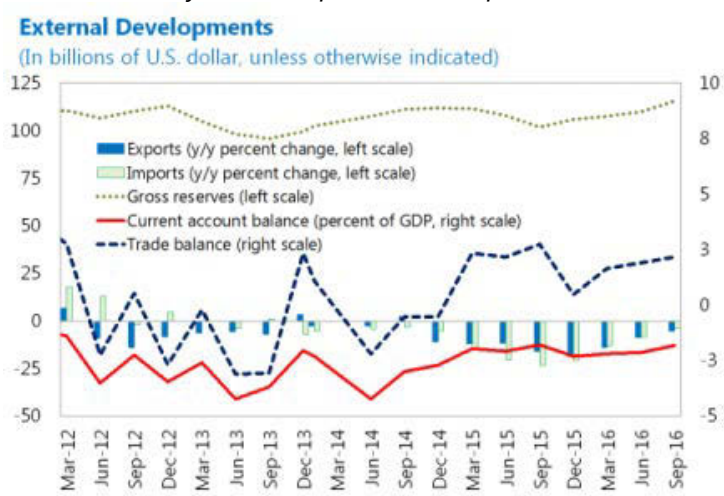

Sources: CEIC Data Company Ltd, and IMF staff estimates.

A contraction in exports has seen some stabilization as the downturn in commodity prices has stabilized...

Exports of Goods

(Year-on-year percentage change of USS value)

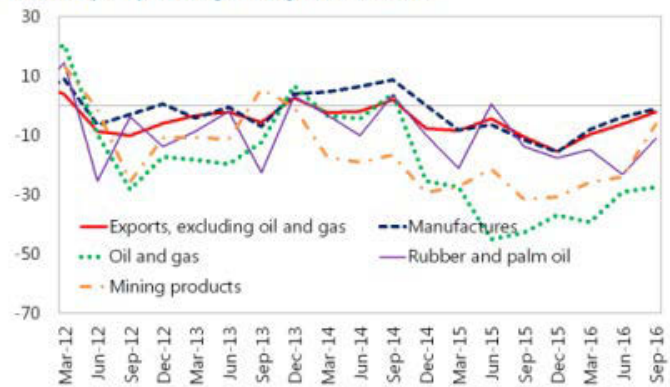

Sources: CEIC Data Company Ltd: and IMF staff estimates.

External financing needs are expected to remain stable in 2017 and risk will likely be contained...

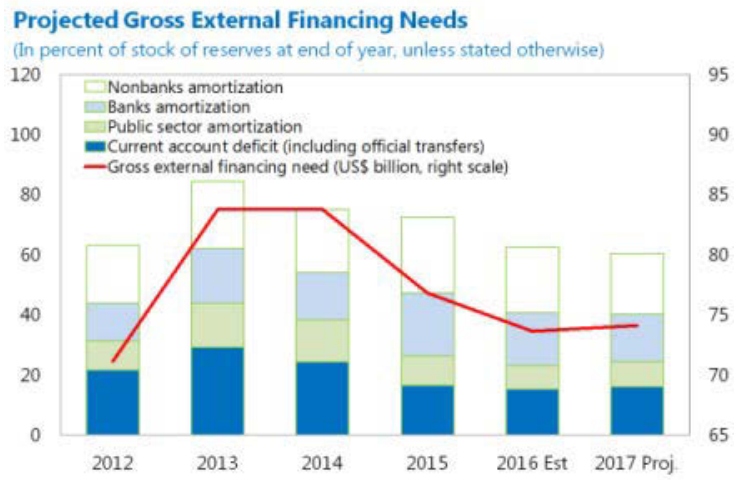

Source: IMF staff estimates
... as reflected in the improvement in the non-oil and gas trade balance.

Current Account Balance

(In percent of GDP)

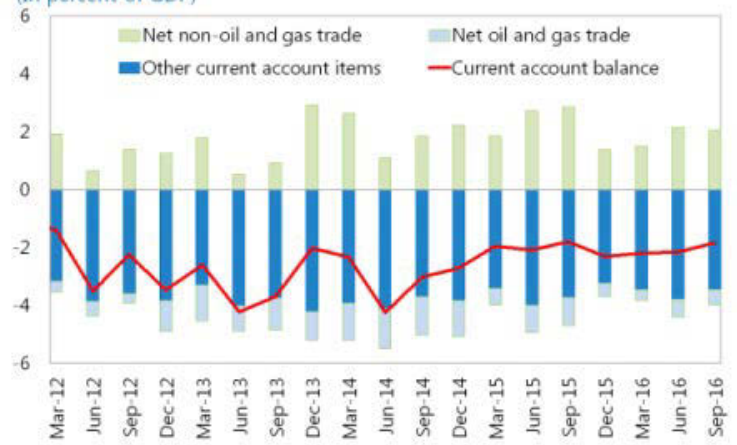
Sources: CEIC Data Company Ltd.; and IMF staff estimates

...while the weakness in imports appears to have bottomed out.

Imports of Goods

(In percentage change of US\$ values, year-on-year)

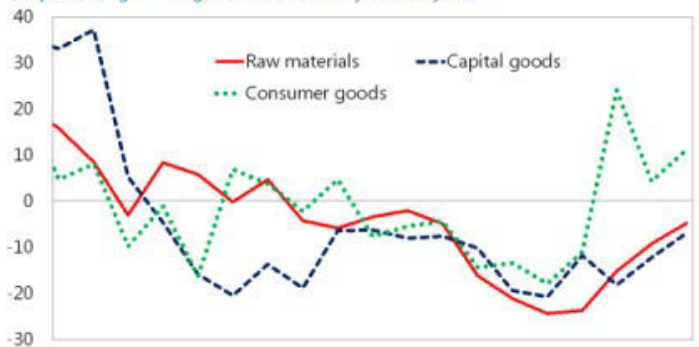

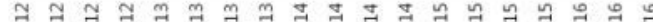

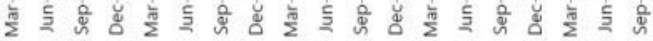

Source: CEIC Data Company Ltd.

....as Indonesia's level of reserves is seen as sufficient to deal with most shocks and compares well against EM peers.

Reserve Adequacy Composite Matrix

(In percent)

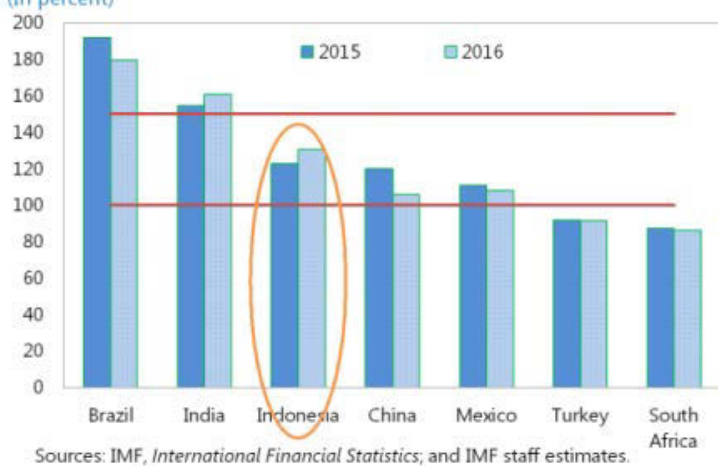




\section{Figure 6. Indonesia: Fiscal Sector}

The fiscal deficit remains wide, mainly driven by a fall in oil and gas revenues, despite cuts in energy subsidies.

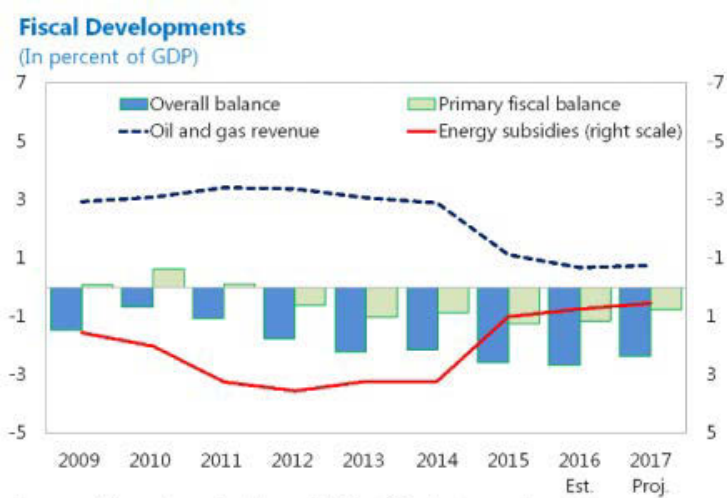

Sources: Indonesian authorities; and IMF staff estimates and projections.

Revenue relative to GDP declined due to a weakness in resource revenues, while nonresource revenues constrained.

Central Government Revenue

(In percent of GDP)

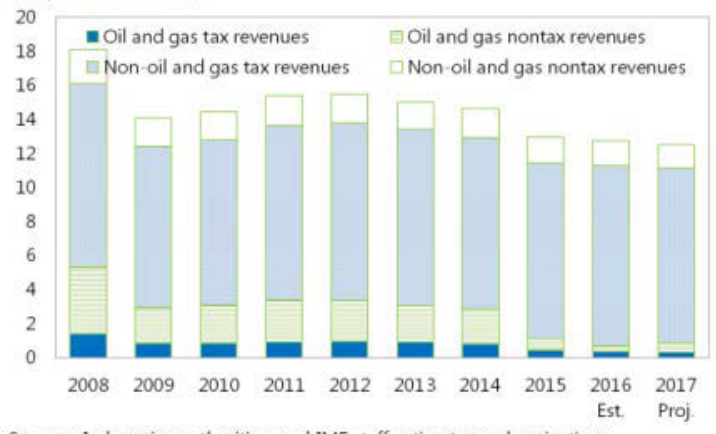

Sources: Indonesian authorities; and IMF staff estimates and projections

Energy subsidy reforms since 2015 freed up space for capital spending, which has increased substantially.

Central Government Expenditure

(In percent of GDP)

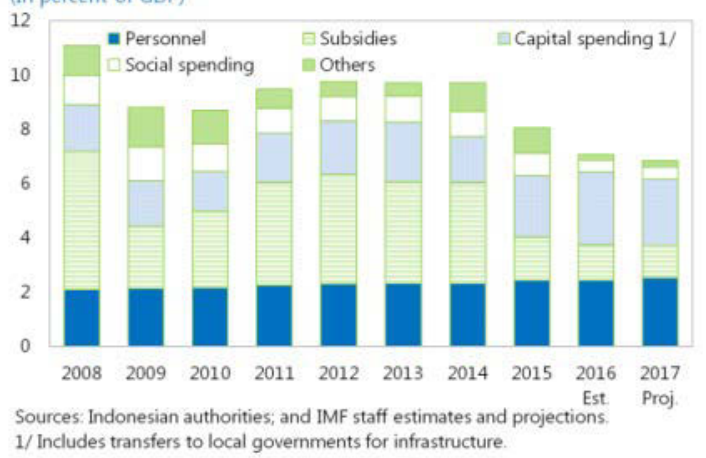

Gradual fiscal consolidation was initiated in August 2016.

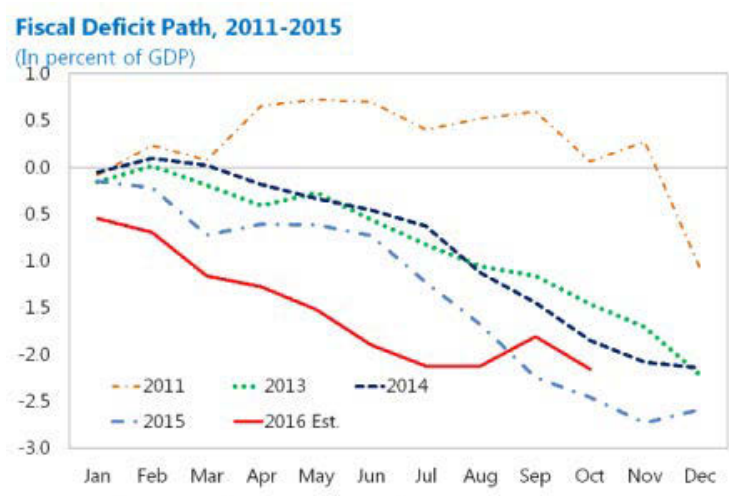

Sources: Indonesian authorities; and IMF staff estimates.

...with Indonesia's tax-to-GDP ratio ranking the lowest among regional EM peers.

General Government Tax-to-GDP Ratio, 2015

(In percent)

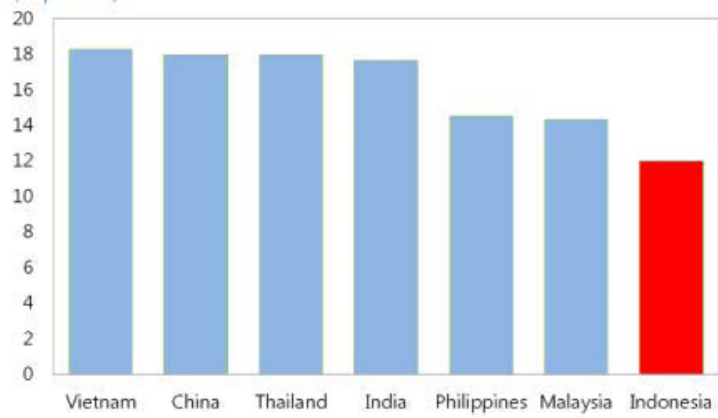

Sources: IMF, WEO Database; and Authority data.

The public debt-to-GDP ratio has risen on weak revenues and rupiah depreciation, but remains at a comparatively low level.

Public Debt, Primary, and Cyclically Adjusted Balance

(In percent of GDP)

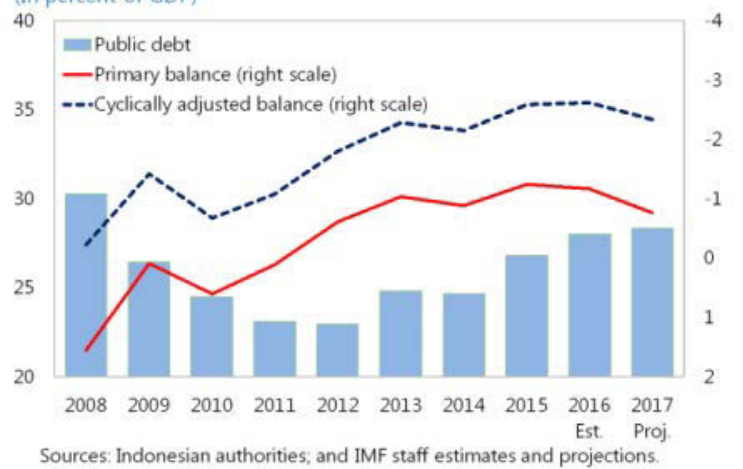




\section{Figure 7. Indonesia: Monetary Sector and Bank Liquidity Developments}

Credit growth has moderated significantly.

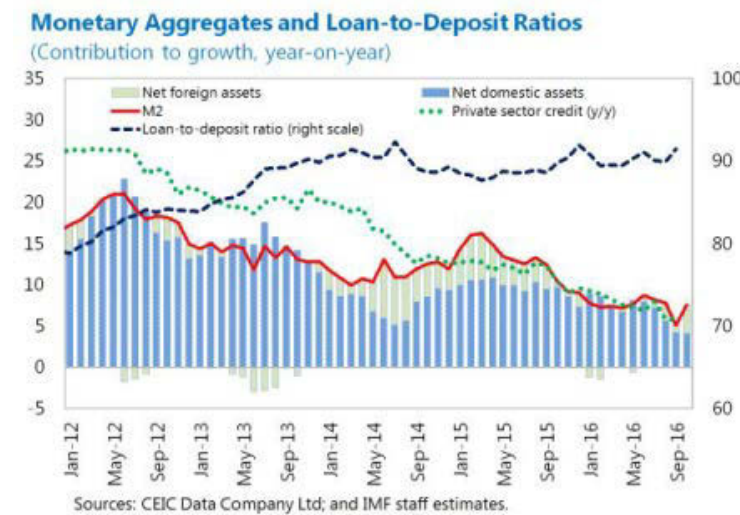

Net available funding continues to be constrained due to slow deposit growth...

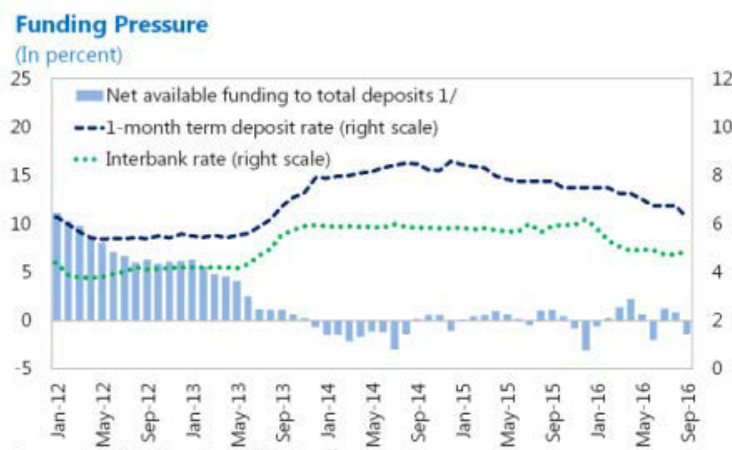

Sources: Bank Indonesia; and IMF staff estimates

1/ Net available funding is defined as third-party funding less third-party credit and statutory reserves.

BI reduced its policy rate by a cumulative 150 bps in 2016 on lower inflation and reduced pressure on the rupiah.

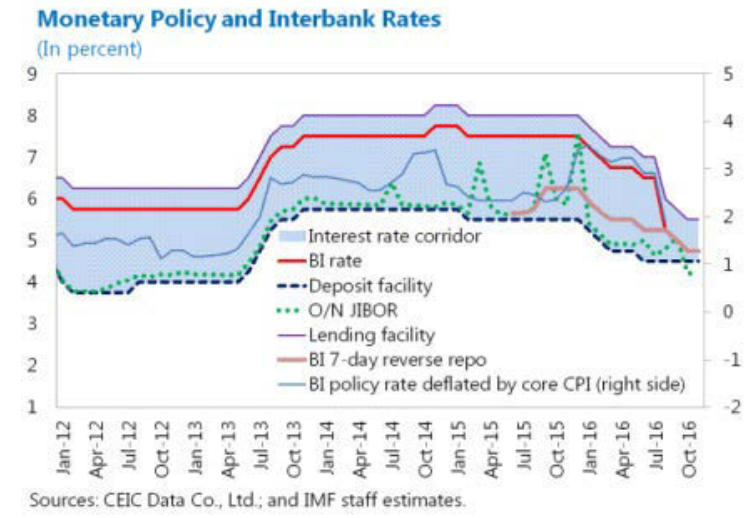

Loan-to-deposit ratios (LDR) remain elevated on slow deposit growth, though FX LDR has declined on weak FX loan demand.

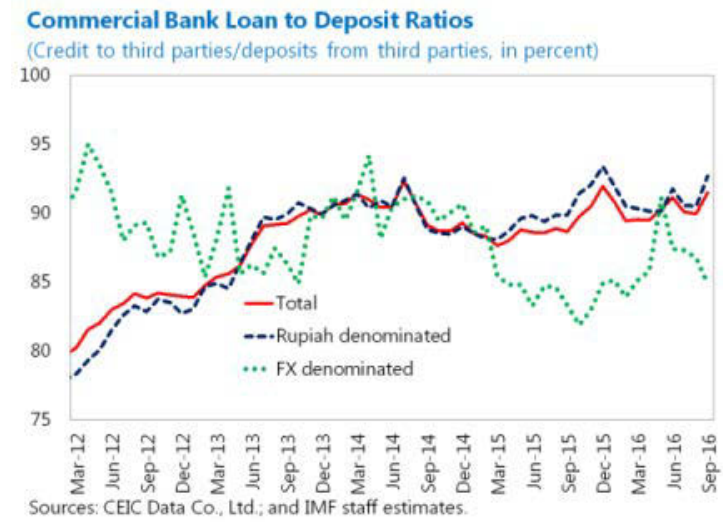

...although banks' interest margins remain wide, as deposit rates declined more than lending rates.

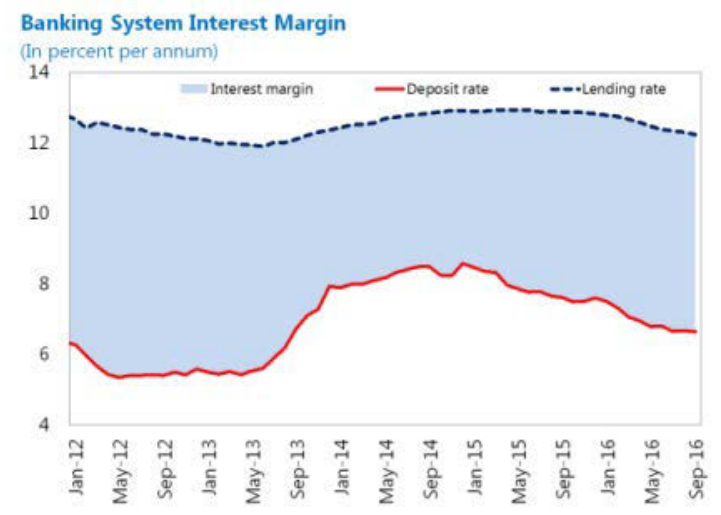

$B I$ increased liquidity absorption since the announcement of $a$ shift in policy rates, to firm up the short end of the yield curve.

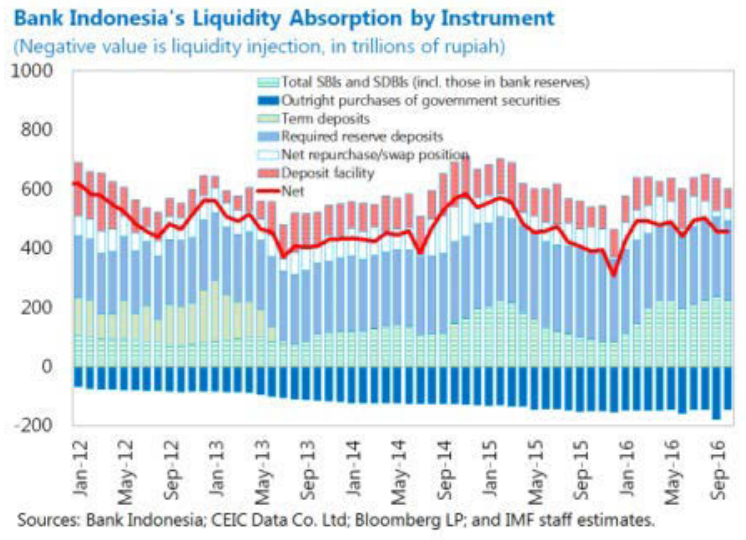


Figure 8. Selected Emerging Market Economies: Financial Soundness Indicators, 2016:Q2

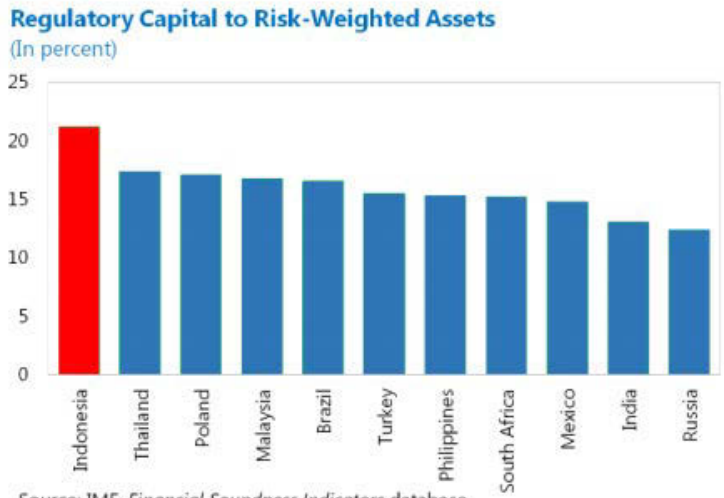

Source: IMF, Financial Soundness Indicators database.

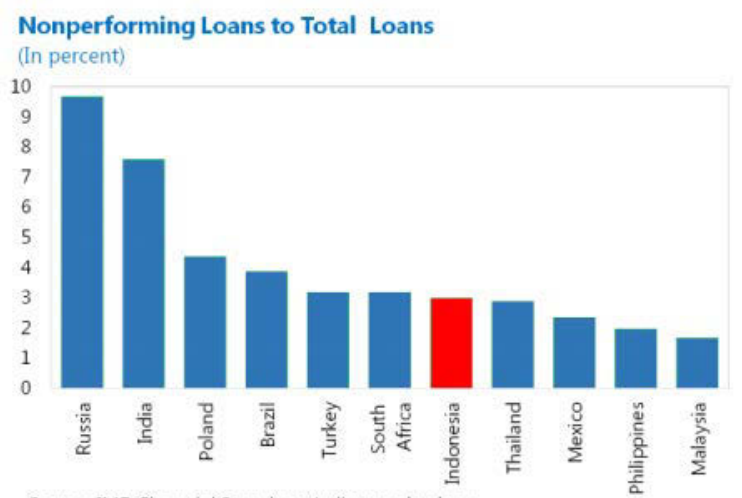

Source: IMF, Financial Soundness Indicators database

Liquid Assets to Total Assets

(In percent)

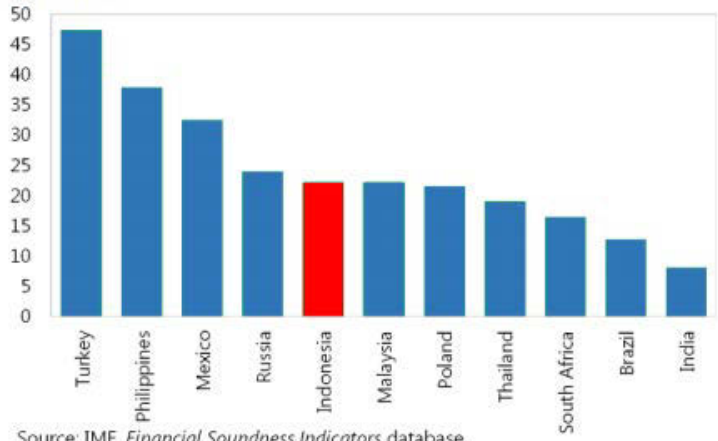

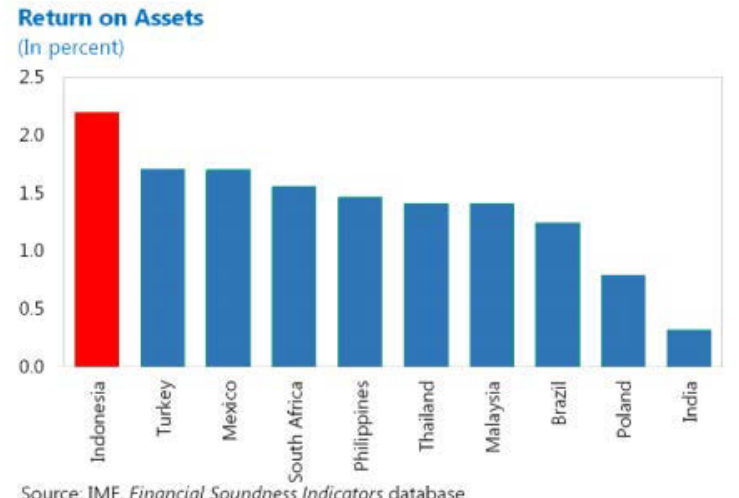

Source: IMF, Financial Soundness Indicators database

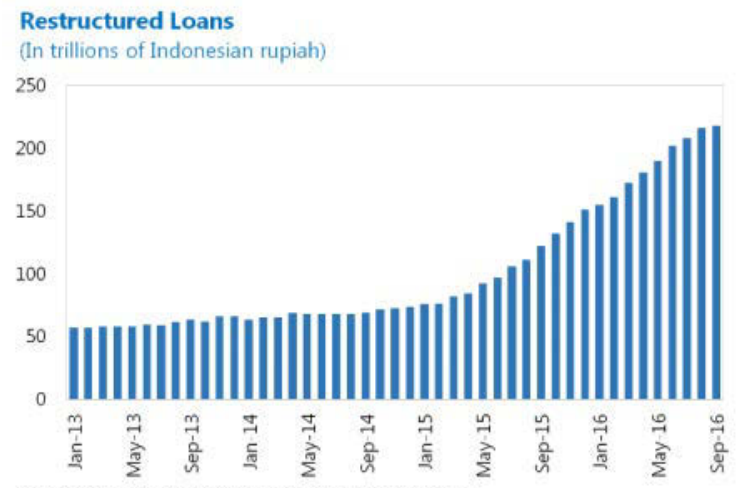

Source: IMF, Financial Soundness Indicators database.

Liquid Assets to Short-Term Liabilities (In percent)

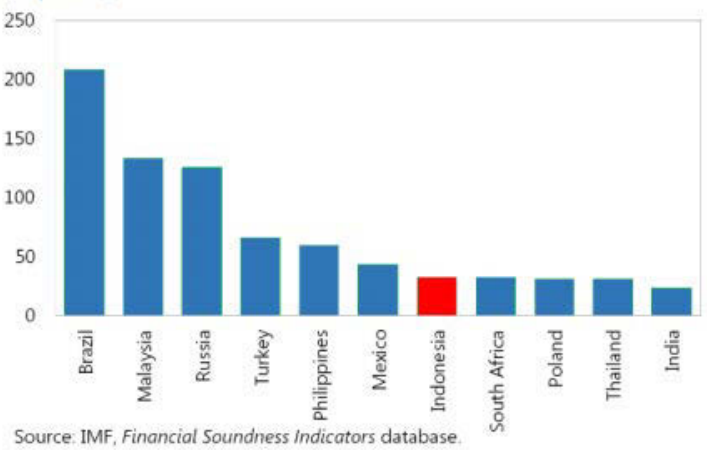




\section{Figure 9. Financial Soundness Indicators by Size of Commercial Banks}
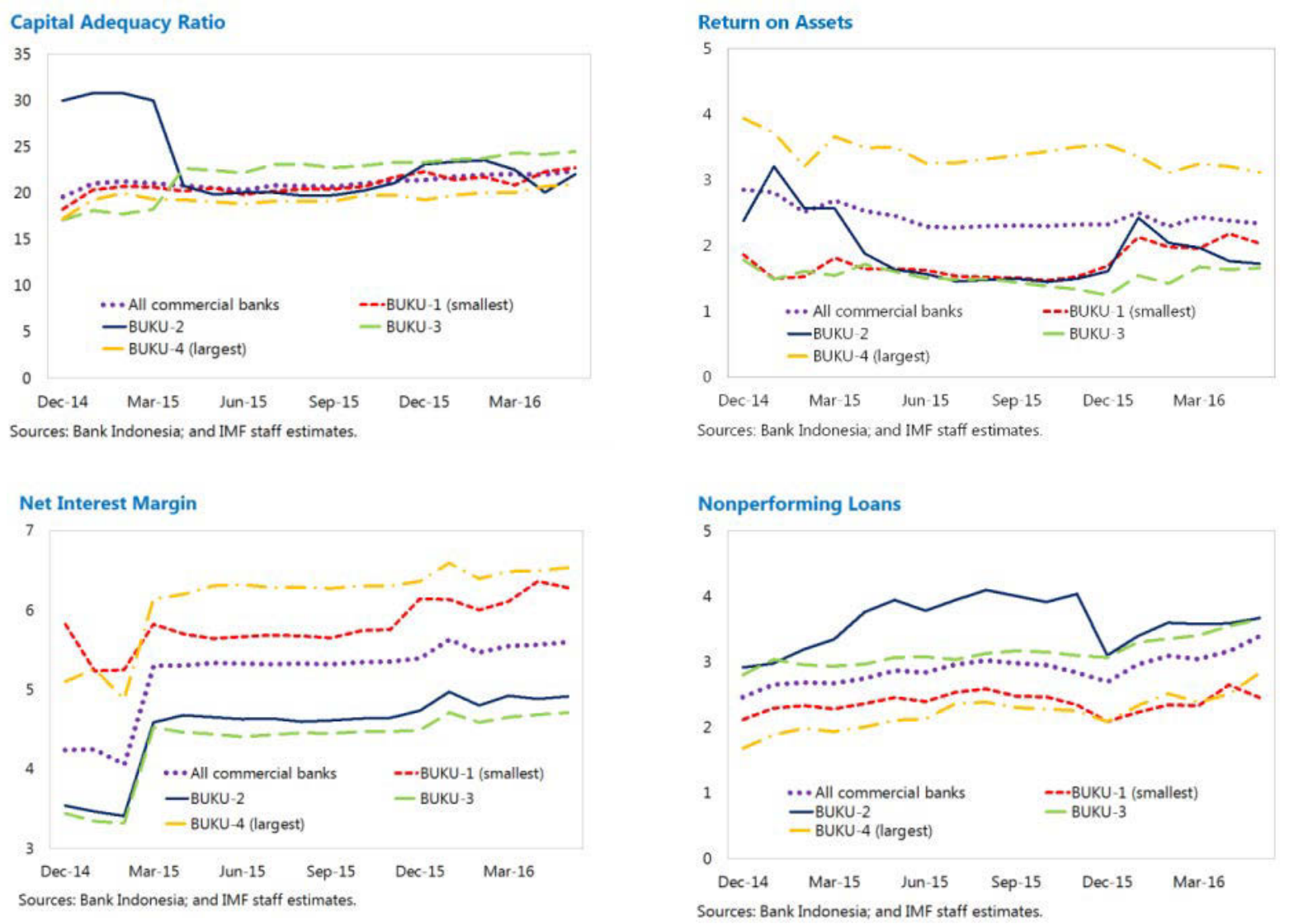
Table 1. Indonesia: Selected Economic Indicators, 2012-17

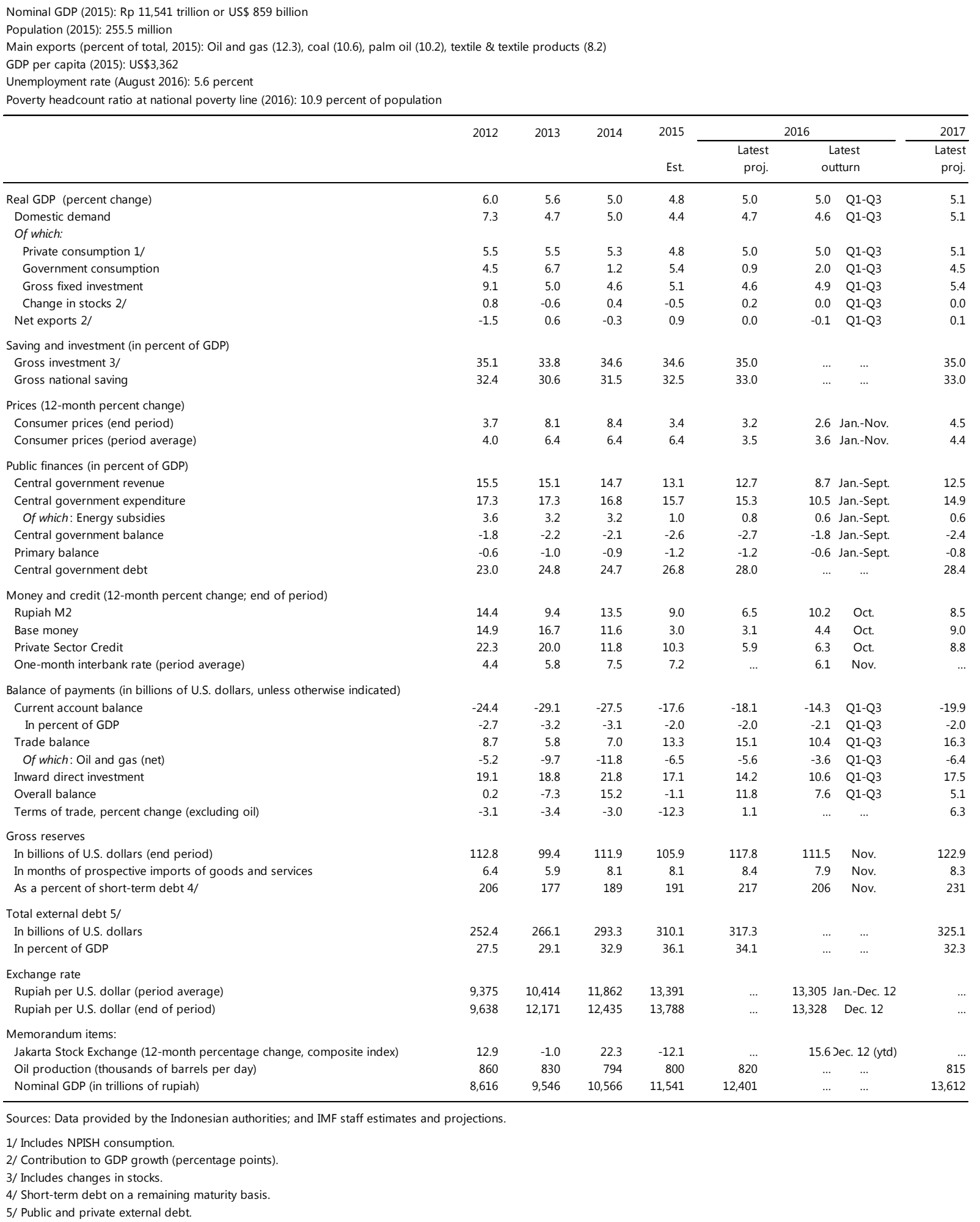

\section{CInternational Monetary Fund. Not for Redistribution}


Table 2. Indonesia: Selected Vulnerability Indicators, 2012-16

\begin{tabular}{|c|c|c|c|c|c|c|}
\hline & 2012 & 2013 & 2014 & $\begin{array}{l}2015 \\
\text { Prel. }\end{array}$ & $\begin{array}{r}2016 \\
\text { Proj. } \\
\text { or latest }\end{array}$ & Observation \\
\hline \multicolumn{7}{|l|}{ Key economic and market indicators } \\
\hline Real GDP growth (in percent) & 6.0 & 5.6 & 5.0 & 4.8 & 5.0 & Proj. \\
\hline CPI inflation (in percent, end of period, e.o.p.) & 3.7 & 8.1 & 8.4 & 3.4 & 3.2 & Proj. \\
\hline Short-term (ST) interest rate (in percent, e.o.p.) 1/ & 4.8 & 7.6 & 6.6 & 8.6 & 6.1 & Nov. 2016 \\
\hline Ten-year government bond yield (in percent, e.o.p.) & 5.3 & 8.5 & 7.8 & 8.7 & 8.1 & Nov. 2016 \\
\hline Indonesia EMBI spread (basis points (bps), e.o.p.) & 179 & 292 & 266 & 329 & 229 & Nov. 2016 \\
\hline Exchange rate (rupiah per U.S. dollar, e.o.p.) & 9,638 & 12,171 & 12,435 & 13,788 & $\ldots$ & \\
\hline \multicolumn{7}{|l|}{ External sector } \\
\hline Current account balance (in percent of GDP) & -2.7 & -3.2 & -3.1 & -2.0 & -2.0 & Proj. \\
\hline Net FDI inflows (in percent of GDP) & 1.5 & 1.3 & 1.7 & 1.3 & 1.5 & Proj. \\
\hline Exports of goods and nonfactor services (GNFS) (percentage change, in US\$ terms) & -0.9 & -2.8 & -3.0 & -14.2 & -3.1 & Proj. \\
\hline Real effective exchange rate (e.o.p.; $2010=100)$ & 94.4 & 83.4 & 92.2 & 91.2 & 94.0 & Sept. 2016 \\
\hline Gross international reserves (in US\$ billion) & 112.8 & 99.4 & 111.9 & 105.9 & 117.8 & Proj. \\
\hline In percent of ST debt at remaining maturity (RM) & 206.4 & 176.6 & 188.8 & 190.9 & 217.3 & Proj. \\
\hline Total gross external debt (in percent of exports of GNFS) & 119.6 & 129.8 & 147.5 & 181.7 & 192.0 & Proj. \\
\hline Gross external financing requirement (in US\$ billion) 2/ & 71.2 & 83.8 & 83.8 & 76.8 & 73.6 & Proj. \\
\hline \multicolumn{7}{|l|}{ Public sector (PS) $3 /$} \\
\hline Overall balance (in percent of GDP) & -1.8 & -2.2 & -2.1 & -2.6 & -2.7 & Proj. \\
\hline Primary balance (in percent of GDP) & -0.6 & -1.0 & -0.9 & -1.2 & -1.2 & Proj. \\
\hline Gross PS financing requirement (in percent of GDP) 4/ & 3.7 & 4.0 & 4.4 & 4.2 & 4.6 & Proj. \\
\hline Public sector gross debt (PSGD) (in percent of GDP) & 23.0 & 24.8 & 24.7 & 26.8 & 28.0 & Proj. \\
\hline Of which: Exposed to rollover risk (in percent of total PSGD) 5/ & 6.9 & 7.0 & 7.6 & 6.6 & 7.6 & Proj. \\
\hline Exposed to exchange rate risk (in percent of total PSGD) 6/ & 44.5 & 46.7 & 43.3 & 43.8 & 40.3 & Proj. \\
\hline Exposed to interest rate risk (in percent of total PSGD) 7/ & 7.4 & 5.2 & 4.0 & 2.8 & 2.0 & Proj. \\
\hline \multicolumn{7}{|l|}{ Financial sector (FS) } \\
\hline Capital to risk-weighted assets (in percent) 8/ & 17.3 & 19.8 & 18.7 & 20.2 & 21.2 & Jun. 2016 \\
\hline Nonperforming loans (in percent of total loans) & 1.8 & 1.7 & 2.2 & 2.7 & 3.1 & Sept. 2016 \\
\hline Foreign currency deposits at commercial banks (in percent of total deposits) & 14.3 & 17.0 & 15.9 & 16.5 & 14.5 & Oct. 2016 \\
\hline Foreign exchange loans at commercial banks (in percent of total loans) & 15.0 & 16.5 & 15.7 & 14.4 & 13.0 & Oct. 2016 \\
\hline Government debt held by financial system (percent of total financial system assets) & 5.7 & 5.9 & 6.0 & 7.5 & 8.4 & Oct. 2016 \\
\hline Total credit outstanding of banking system (annual percentage change) & 23.1 & 21.4 & 11.6 & 10.1 & 7.4 & Oct. 2016 \\
\hline
\end{tabular}

Sources: Data provided by the Indonesian authorities; and IMF staff estimates and projections.

1/ One-month Jakarta Interbank offered rate.

2/ Defined as current account deficit, plus amortization on medium- and long-term debt and short-term debt at end of previous period.

3/ Public sector covers central government only.

4/ Overall balance plus debt amortization.

5/ Short-term debt and maturing medium- and long-term debt.

6/ Debt in foreign currency or linked to the exchange rate.

7/ Government securities at variable interest rates.

8/ Includes capital charge for operational risk. 
Table 3. Indonesia: Balance of Payments, 2012-17

(In billions of U.S. dollar, unless otherwise indicated)

\begin{tabular}{|c|c|c|c|c|c|c|}
\hline & 2012 & 2013 & 2014 & $\begin{array}{r}2015 \\
\text { Est. }\end{array}$ & $\begin{array}{l}2016 \\
\text { Proj. }\end{array}$ & $\begin{array}{l}2017 \\
\text { Proj. }\end{array}$ \\
\hline Current account & -24.4 & -29.1 & -27.5 & -17.6 & -18.1 & -19.9 \\
\hline Goods, net (trade balance) & 8.7 & 5.8 & 7.0 & 13.3 & 15.1 & 16.3 \\
\hline Exports, f.o.b. & 187.3 & 182.1 & 175.3 & 148.4 & 142.2 & 151.9 \\
\hline Oil and gas & 35.6 & 33.6 & 28.8 & 16.4 & 12.6 & 14.9 \\
\hline Non-oil and gas $1 /$ & 151.8 & 148.5 & 146.5 & 131.9 & 129.5 & 137.0 \\
\hline Of which: Manufacturing & 112.2 & 109.3 & 115.4 & 104.8 & 102.7 & 107.3 \\
\hline Palm oil & 17.7 & 16.5 & 17.5 & 15.4 & 13.1 & 13.4 \\
\hline Rubber products & 10.4 & 9.3 & 7.0 & 5.8 & 5.8 & 7.4 \\
\hline Other manufacturing & 84.1 & 83.5 & 91.0 & 83.5 & 83.8 & 86.5 \\
\hline Mining & 31.4 & 30.4 & 21.8 & 19.5 & 19.5 & 22.2 \\
\hline Imports, f.o.b. & -178.7 & -176.3 & -168.3 & -135.1 & -127.1 & -135.6 \\
\hline Oil and gas & -40.8 & -43.3 & -40.6 & -22.9 & -18.2 & -21.3 \\
\hline Non-oil and gas & -137.9 & -133.0 & -127.7 & -112.2 & -108.9 & -114.2 \\
\hline Services, net & -10.6 & -12.1 & -10.0 & -8.3 & -7.1 & -8.9 \\
\hline Income, net & -26.6 & -27.1 & -29.7 & -28.1 & -31.0 & -32.5 \\
\hline Current transfers, net & 4.1 & 4.2 & 5.2 & 5.5 & 4.9 & 5.2 \\
\hline Capital and financial account & 24.9 & 22.0 & 44.9 & 16.8 & 30.3 & 25.0 \\
\hline Capital account & 0.1 & 0.0 & 0.0 & 0.0 & 0.0 & 0.0 \\
\hline Financial account & 24.9 & 21.9 & 44.9 & 16.8 & 30.2 & 25.0 \\
\hline Direct investment, net & 13.7 & 12.2 & 14.7 & 10.8 & 13.6 & 16.5 \\
\hline Abroad, net & -5.4 & -6.6 & -7.1 & -6.3 & -0.5 & -0.9 \\
\hline In Indonesia (FDI), net & 19.1 & 18.8 & 21.8 & 17.1 & 14.2 & 17.5 \\
\hline Portfolio investment, net & 9.2 & 10.9 & 26.1 & 16.4 & 18.8 & 11.3 \\
\hline Assets, net & -5.5 & -1.3 & 2.6 & -1.3 & 2.1 & 0.4 \\
\hline Liabilities & 14.7 & 12.1 & 23.5 & 17.7 & 16.7 & 10.9 \\
\hline Equity securities & 1.7 & -1.9 & 3.3 & -1.5 & 1.4 & 0.5 \\
\hline Debt securities & 13.0 & 14.0 & 20.2 & 19.2 & 15.3 & 10.4 \\
\hline Other investment & 1.9 & -0.8 & 4.3 & -10.5 & -2.2 & -2.9 \\
\hline Assets & -5.4 & -3.4 & -3.4 & -11.8 & 5.3 & 0.3 \\
\hline Public sector & 0.0 & 0.0 & 0.0 & 0.0 & -0.3 & 0.0 \\
\hline Private sector & -5.4 & -3.4 & -3.4 & -11.8 & 5.3 & 0.3 \\
\hline Liabilities & 7.3 & 2.6 & 7.7 & 1.4 & -7.5 & -3.2 \\
\hline Public sector & 2.5 & -1.4 & -4.2 & -0.5 & -2.3 & -1.3 \\
\hline Private sector & 4.8 & 4.0 & 11.9 & 1.8 & -5.2 & -1.9 \\
\hline Total & 0.5 & -7.1 & 17.4 & -0.8 & 12.1 & 5.1 \\
\hline Errors and omissions & -0.3 & -0.2 & -2.2 & -0.3 & 0.0 & 0.0 \\
\hline Overall balance & 0.2 & -7.3 & 15.2 & -1.1 & 12.1 & 5.1 \\
\hline Valuation changes & 2.4 & -6.1 & -2.8 & -4.8 & -0.3 & 0.0 \\
\hline Change in reserve assets (- = increase) & -2.7 & 13.4 & -12.5 & 5.9 & -11.8 & -5.1 \\
\hline \multicolumn{7}{|l|}{ Memorandum items: } \\
\hline Reserve assets position (eop) & 112.8 & 99.4 & 111.9 & 105.9 & 117.8 & 122.9 \\
\hline In months of prospective imports of goods and services & 6.4 & 5.9 & 8.1 & 8.1 & 8.4 & 8.3 \\
\hline In percent of short-term (ST) debt at remaining maturity (RM) & 206 & 177 & 189 & 191 & 217 & 231 \\
\hline In percent of ST debt at RM plus the current account deficit & 135 & 119 & 146 & 144 & 159 & 161 \\
\hline Current account (- deficit, percent of GDP) & -2.7 & -3.2 & -3.1 & -2.0 & -2.0 & -2.0 \\
\hline Non-oil and gas exports, volume growth & 7.1 & 4.2 & 5.1 & 0.7 & -14.3 & -1.4 \\
\hline Non-oil and gas imports, volume growth & 17.1 & -1.2 & -0.8 & 2.2 & -0.6 & 2.5 \\
\hline Terms of trade, percent change (excluding oil) & -3.1 & -3.4 & -3.0 & -12.3 & 1.1 & 6.3 \\
\hline Terms of trade, percent change (including oil) & -3.1 & -3.7 & -2.2 & -0.6 & 3.9 & 2.7 \\
\hline Gross external financing requirement (in US $\$$ billion) 2/ & 71.2 & 83.8 & 83.8 & 76.8 & 73.6 & 74.1 \\
\hline
\end{tabular}


Table 4. Indonesia: Medium-Term Macroeconomic Framework, 2014-21

\begin{tabular}{|c|c|c|c|c|c|c|c|c|}
\hline & 2014 & 2015 & 2016 & 2017 & 2018 & 2019 & 2020 & 2021 \\
\hline & & Est. & \multicolumn{6}{|c|}{ Proj. } \\
\hline Real GDP (percent change) & 5.0 & 4.8 & 5.0 & 5.1 & 5.3 & 5.4 & 5.5 & 5.5 \\
\hline $\begin{array}{l}\text { Domestic demand } \\
\text { Of which: }\end{array}$ & 5.0 & 4.4 & 4.7 & 5.1 & 5.2 & 5.4 & 5.4 & 5.4 \\
\hline Private consumption $1 /$ & 5.3 & 4.8 & 5.0 & 5.1 & 5.2 & 5.3 & 5.3 & 5.3 \\
\hline Gross fixed investment & 4.6 & 5.1 & 4.6 & 5.4 & 5.7 & 6.0 & 6.2 & 6.2 \\
\hline Change in stocks $2 /$ & 0.4 & -0.5 & 0.2 & 0.0 & 0.0 & 0.0 & 0.0 & 0.0 \\
\hline Net exports 2/ & -0.3 & 0.9 & 0.0 & 0.1 & 0.2 & 0.2 & 0.2 & 0.2 \\
\hline Statistical discrepancy 2/ & 0.4 & -0.4 & 0.4 & 0.0 & 0.0 & 0.0 & 0.0 & 0.0 \\
\hline Output gap & 0.1 & -0.1 & -0.4 & -0.2 & -0.1 & -0.1 & 0.0 & 0.0 \\
\hline \multicolumn{9}{|l|}{ Saving and investment (in percent of GDP) } \\
\hline Gross investment 3/ & 34.6 & 34.6 & 35.0 & 35.0 & 35.1 & 35.2 & 35.3 & 35.5 \\
\hline Gross national saving & 31.5 & 32.5 & 33.0 & 33.0 & 32.9 & 33.0 & 33.1 & 33.2 \\
\hline Foreign saving (external current account balance) & 3.1 & 2.0 & 2.0 & 2.0 & 2.1 & 2.2 & 2.2 & 2.3 \\
\hline \multicolumn{9}{|l|}{ Prices (12-month percent change) } \\
\hline Consumer prices (end period) & 8.4 & 3.4 & 3.2 & 4.5 & 4.4 & 4.2 & 4.0 & 4.0 \\
\hline Consumer prices (period average) & 6.4 & 6.4 & 3.5 & 4.4 & 4.5 & 4.3 & 4.1 & 4.0 \\
\hline \multicolumn{9}{|l|}{ Public finances (in percent of GDP) } \\
\hline General governemnt revenue & 16.5 & 14.9 & 14.5 & 14.3 & 14.2 & 14.2 & 14.2 & 14.3 \\
\hline General governemnt expenditure & 18.6 & 17.4 & 17.2 & 16.7 & 16.7 & 16.7 & 16.8 & 16.8 \\
\hline General government balance & -2.1 & -2.5 & -2.7 & -2.4 & -2.5 & -2.5 & -2.5 & -2.5 \\
\hline General governemnt primary balance & -0.9 & -1.1 & -1.2 & -0.8 & -0.8 & -0.8 & -0.8 & -0.8 \\
\hline General government debt & 24.7 & 26.8 & 28.0 & 28.4 & 28.7 & 29.2 & 29.2 & 29.4 \\
\hline Central government revenue & 14.7 & 13.1 & 12.7 & 12.5 & 12.4 & 12.4 & 12.4 & 12.5 \\
\hline Of which: Non-oil and gas tax revenues & 10.0 & 10.3 & 10.5 & 10.2 & 10.2 & 10.3 & 10.3 & 10.4 \\
\hline Central government expenditure & 16.8 & 15.7 & 15.3 & 14.9 & 14.9 & 14.9 & 15.0 & 15.0 \\
\hline Of which: Energy subsidies & 3.2 & 1.0 & 0.8 & 0.6 & 0.5 & 0.5 & 0.4 & 0.4 \\
\hline Development expenditure & 2.3 & 2.7 & 2.3 & 1.5 & 1.5 & 1.5 & 1.6 & 1.6 \\
\hline Central government balance & -2.1 & -2.6 & -2.7 & -2.4 & -2.5 & -2.5 & -2.5 & -2.5 \\
\hline \multicolumn{9}{|l|}{ Balance of payments (in billions of U.S. dollars) } \\
\hline Current account balance & -27.5 & -17.6 & -18.1 & -19.9 & -23.4 & -25.8 & -29.1 & -33.1 \\
\hline In percent of GDP & -3.1 & -2.0 & -2.0 & -2.0 & -2.1 & -2.2 & -2.2 & -2.3 \\
\hline Trade balance & 7.0 & 13.3 & 15.1 & 16.3 & 17.5 & 18.0 & 18.5 & 18.3 \\
\hline In percent of GDP & 0.8 & 1.5 & 1.6 & 1.6 & 1.6 & 1.5 & 1.4 & 1.2 \\
\hline Of which: Oil and gas (net) & -11.8 & -6.5 & -5.6 & -6.4 & -6.4 & -6.2 & -6.3 & -6.2 \\
\hline Service balance (in percent of GDP) & -1.1 & -1.0 & -0.8 & -0.9 & -0.9 & -0.8 & -0.9 & -0.8 \\
\hline Overall balance & 15.2 & -1.1 & 11.8 & 5.1 & 4.7 & 5.2 & 6.8 & 5.8 \\
\hline \multicolumn{9}{|l|}{ Gross reserves } \\
\hline In billions of U.S. dollars (end period) & 111.9 & 105.9 & 117.8 & 122.9 & 127.6 & 132.8 & 139.6 & 145.4 \\
\hline In months of prospective imports & 8.1 & 8.1 & 8.4 & 8.3 & 8.1 & 7.8 & 7.6 & 7.4 \\
\hline As a percent of short-term debt 4 / & 188.8 & 190.9 & 217.3 & 231.3 & 244.5 & 259.7 & 279.2 & 298.9 \\
\hline \multicolumn{9}{|l|}{ Total external debt } \\
\hline In billions of U.S. dollars & 293.3 & 310.1 & 317.3 & 325.1 & 337.7 & 351.0 & 364.7 & 378.3 \\
\hline In percent of GDP & 32.9 & 36.1 & 34.1 & 32.3 & 30.6 & 29.3 & 27.7 & 25.8 \\
\hline \multicolumn{9}{|l|}{ Credit } \\
\hline Private Sector Credit & 11.8 & 10.3 & 5.9 & 8.8 & 9.6 & 10.5 & 11.5 & 12.6 \\
\hline \multicolumn{9}{|l|}{ Memorandum items: } \\
\hline Oil production (thousands of barrels per day) & 794 & 800 & 820 & 815 & 770 & 740 & 710 & 710 \\
\hline Indonesian oil price (period average, in U.S. dollars per barrel) & 96.5 & 49.2 & 41.3 & 50.2 & 51.7 & 52.1 & 53.3 & 54.5 \\
\hline Nominal GDP (in trillions of rupiah) & 10,566 & 11,541 & 12,401 & 13,612 & 14,971 & 16,456 & 18,069 & 19,820 \\
\hline Nominal GDP (in billions of U.S. dollars) & 891 & 859 & $\ldots$ & $\ldots$ & $\ldots$ & $\ldots$ & $\ldots$ & $\ldots$ \\
\hline
\end{tabular}

Sources: Data provided by the Indonesian authorities; and IMF staff estimates and projections.

1/ Includes NPISH consumption.

2/ Contribution to GDP growth.

3 / Includes changes in stocks.

4/ Short-term debt on a remaining maturity basis 
Table 5. Indonesia: Summary of Central Government Operations, 2012-17

(In trillions of rupiah)

\begin{tabular}{|c|c|c|c|c|c|c|c|}
\hline & \multirow[t]{2}{*}{2012} & \multirow[t]{2}{*}{2013} & \multirow[t]{2}{*}{2014} & \multirow[t]{2}{*}{2015} & \multirow{2}{*}{$\begin{array}{r}2016 \\
\text { Latest proj. }\end{array}$} & \multicolumn{2}{|c|}{2017} \\
\hline & & & & & & Latest proj. & Budget \\
\hline Revenues and grants & 1,338 & 1,439 & 1,550 & 1,508 & 1,581 & 1,701 & 1,750 \\
\hline Of which: tax revenues & 981 & 1,077 & 1,147 & 1,240 & 1,358 & 1,441 & 1,499 \\
\hline Oil and gas revenues & 289 & 292 & 304 & 128 & 85 & 119 & 100 \\
\hline Tax revenues & 83 & 89 & 87 & 50 & 46 & 46 & 36 \\
\hline Nontax revenues & 206 & 204 & 217 & 78 & 40 & 73 & 64 \\
\hline Non-oil and gas revenues & 1,043 & 1,140 & 1,241 & 1,368 & 1,494 & 1,581 & 1,649 \\
\hline Tax revenues & 897 & 989 & 1,059 & 1,191 & 1,313 & 1,395 & 1,463 \\
\hline Income tax & 382 & 418 & 459 & 553 & 679 & 706 & 752 \\
\hline Of which: tax amnesty & & & & & 110 & 5 & $\ldots$ \\
\hline VAT & 338 & 385 & 409 & 424 & 424 & 474 & 494 \\
\hline Other & 178 & 186 & 192 & 214 & 209 & 215 & 217 \\
\hline Nontax revenues & 146 & 151 & 182 & 177 & 181 & 186 & 186 \\
\hline Grants & 6 & 7 & 5 & 12 & 2 & 1 & 1 \\
\hline Expenditure and net lending & 1,491 & 1,651 & 1,777 & 1,808 & 1,913 & 2,024 & 2,080 \\
\hline Current expenditure & 790 & 864 & 958 & 871 & 909 & 1,052 & 1,055 \\
\hline Personnel & 198 & 222 & 244 & 281 & 302 & 345 & 345 \\
\hline Subsidies & 346 & 355 & 392 & 186 & 162 & 160 & 160 \\
\hline Of which: energy subsidies & 306 & 310 & 342 & 119 & 95 & 77 & 77 \\
\hline Fuel & 212 & 210 & 240 & 61 & 44 & 32 & 32 \\
\hline Electricity & 95 & 100 & 102 & 58 & 51 & 45 & 45 \\
\hline Interest & 101 & 113 & 133 & 156 & 187 & 218 & 221 \\
\hline Other & 145 & 175 & 189 & 248 & 257 & 328 & 329 \\
\hline Development expenditure & 221 & 273 & 245 & 314 & 297 & 207 & 260 \\
\hline Capital spending & 145 & 181 & 147 & 217 & 242 & 148 & 201 \\
\hline Social assistance spending $1 /$ & 76 & 92 & 98 & 97 & 55 & 60 & 60 \\
\hline Transfers to local governments & 481 & 513 & 574 & 623 & 707 & 765 & 765 \\
\hline Of which: transfers for infrastructure 2/ & 26 & 31 & 32 & 39 & 88 & 184 & 184 \\
\hline Overall balance & -153 & -212 & -227 & -300 & -332 & -323 & -330 \\
\hline Financing & 153 & 212 & 227 & 300 & 332 & 323 & 330 \\
\hline Net issuance of government securities & 160 & 225 & 274 & 390 & 400 & 391 & 400 \\
\hline Rupiah bond issuance & 227 & 269 & 353 & 355 & 458 & 495 & $\ldots$ \\
\hline External bond issuance & 56 & 59 & 86 & 160 & 109 & 87 & $\ldots$ \\
\hline Amortization & -123 & -103 & -165 & -124 & -168 & -191 & $\ldots$ \\
\hline Program loan (gross issuance) & 15 & 18 & 18 & 45 & 36 & 13 & 13 \\
\hline SOE recapitalization and land acquisition & $\ldots$ & $\ldots$ & $\ldots$ & -65 & -75 & -55 & -55 \\
\hline Other & $\ldots$ & $\ldots$ & $\ldots$ & -70 & -29 & -27 & -29 \\
\hline
\end{tabular}

Sources: Data provided by the Indonesian authorities; and IMF staff estimates and projections.

1/ Some social assistance spending was reclassified to other expenditure in 2016.

2/ Special purpose transfers (DAK) for infrastructure and Village Fund transfers. Starting 2017, 25 percent of general transfer and revenue sharing is included. 
Table 6. Indonesia: Summary of Central Government Operations, 2012-17

(In percent of GDP, unless otherwise indicated)

\begin{tabular}{|c|c|c|c|c|c|c|c|}
\hline & \multirow[t]{2}{*}{2012} & \multirow[t]{2}{*}{2013} & \multirow[t]{2}{*}{2014} & \multirow{2}{*}{2015} & \multirow{2}{*}{$\begin{array}{r}2016 \\
\text { st proj. }\end{array}$} & \multicolumn{2}{|c|}{2017} \\
\hline & & & & & & Latest proj. & Budget \\
\hline Revenues and grants & 15.5 & 15.1 & 14.7 & 13.1 & 12.8 & 12.5 & 12.9 \\
\hline Of which: tax revenues & 11.4 & 11.3 & 10.9 & 10.7 & 11.0 & 10.6 & 11.0 \\
\hline Oil and gas revenues & 3.4 & 3.1 & 2.9 & 1.1 & 0.7 & 0.9 & 0.7 \\
\hline Tax revenues & 1.0 & 0.9 & 0.8 & 0.4 & 0.4 & 0.3 & 0.3 \\
\hline Nontax revenues & 2.4 & 2.1 & 2.1 & 0.7 & 0.3 & 0.5 & 0.5 \\
\hline Non-oil and gas revenues & 12.1 & 11.9 & 11.7 & 11.9 & 12.0 & 11.6 & 12.1 \\
\hline Tax revenues & 10.4 & 10.4 & 10.0 & 10.3 & 10.6 & 10.2 & 10.7 \\
\hline Income tax & & & 4.3 & 4.8 & 5.5 & 5.2 & 5.5 \\
\hline Of which: tax amnesty & & & & & 0.9 & 0.0 & ... \\
\hline VAT & & & 3.9 & 3.7 & 3.4 & 3.5 & 3.6 \\
\hline Other & & & 1.8 & 1.9 & 1.7 & 1.6 & 1.6 \\
\hline Nontax revenues & 1.7 & 1.6 & 1.7 & 1.5 & 1.5 & 1.4 & 1.4 \\
\hline Grants & 0.1 & 0.1 & 0.0 & 0.1 & 0.0 & 0.0 & 0.0 \\
\hline Expenditure and net lending & 17.3 & 17.3 & 16.8 & 15.7 & 15.4 & 14.9 & 15.3 \\
\hline Current expenditure & 9.2 & 9.1 & 9.1 & 7.5 & 7.3 & 7.7 & 7.8 \\
\hline Personnel & 2.3 & 2.3 & 2.3 & 2.4 & 2.4 & 2.5 & 2.5 \\
\hline Subsidies & 4.0 & 3.7 & 3.7 & 1.6 & 1.3 & 1.2 & 1.2 \\
\hline Of which: energy subsidies & 3.6 & 3.2 & 3.2 & 1.0 & 0.8 & 0.6 & 0.6 \\
\hline Fuel & 2.5 & 2.2 & 2.3 & 0.5 & 0.4 & 0.2 & 0.2 \\
\hline Electricity & 1.1 & 1.0 & 1.0 & 0.5 & 0.4 & 0.3 & 0.3 \\
\hline Interest & 1.2 & 1.2 & 1.3 & 1.4 & 1.5 & 1.6 & 1.6 \\
\hline Other & 1.7 & 1.8 & 1.8 & 2.1 & 2.1 & 2.4 & 2.4 \\
\hline Development expenditure & 2.6 & 2.9 & 2.3 & 2.7 & 2.4 & 1.5 & 1.9 \\
\hline Capital spending & 1.7 & 1.9 & 1.4 & 1.9 & 2.0 & 1.1 & 1.5 \\
\hline Social assistance spending $1 /$ & 0.9 & 1.0 & 0.9 & 0.8 & 0.4 & 0.4 & 0.4 \\
\hline Transfers to local governments & 5.6 & 5.4 & 5.4 & 5.4 & 5.7 & 5.6 & 5.6 \\
\hline Of which: transfers for infrastructure 2/ & 0.3 & 0.3 & 0.3 & 0.3 & 0.7 & 1.3 & 1.3 \\
\hline Overall balance & -1.8 & -2.2 & -2.1 & -2.6 & -2.7 & -2.4 & -2.4 \\
\hline Financing & 1.8 & 2.2 & 2.1 & 2.6 & 2.7 & 2.4 & 2.4 \\
\hline \multicolumn{8}{|l|}{ Memorandum items: } \\
\hline Net issuance of government securities (in trillions of rupiah) & 160 & 225 & 274 & 390 & 400 & 391 & 400 \\
\hline SOE recapitalization and land acquisition (in trillions of rupiah) & $\ldots$ & $\ldots$ & $\ldots$ & 65 & 75 & 55 & 55 \\
\hline Primary balance (percent of GDP) & -0.6 & -1.0 & -0.9 & -1.2 & -1.2 & -0.8 & -0.8 \\
\hline Cyclically-adjusted primary balance (percent of GDP) & -0.6 & -1.1 & -0.9 & -1.2 & -1.1 & -0.7 & ... \\
\hline Capital spending and transfers (percent of GDP) 3 / & 2.0 & 2.2 & 1.7 & 2.2 & 2.6 & 2.4 & 2.8 \\
\hline General government debt (percent of GDP) & 23.0 & 24.8 & 24.7 & 26.8 & 28.0 & 28.4 & $\ldots$ \\
\hline Indonesian crude oil price (US\$ per barrel) & 112.7 & 105.8 & 96.5 & 49.2 & 41.3 & 50.2 & 45.0 \\
\hline Oil production (thousands of barrels per day) & 860 & 830 & 794 & 800 & 820 & 815 & 815 \\
\hline Nominal GDP (in trillions of rupiah) & 8,616 & 9,546 & 10,566 & 11,541 & 12,401 & 13,612 & 13,612 \\
\hline \multicolumn{8}{|c|}{ Sources: Data provided by the Indonesian authorities; and IMF staff estimates and projections. } \\
\hline \multicolumn{8}{|c|}{ 1/ Some social assistance spending was reclassified to other expenditure in 2016.} \\
\hline \multicolumn{8}{|c|}{$\begin{array}{l}\text { 2/ Special purpose transfers (DAK) for infrastructure and Village Fund transfers. Starting 2017, } 25 \text { percent of general transfer and revenue } \\
\text { sharing is included. }\end{array}$} \\
\hline
\end{tabular}


Table 7. Indonesia: Summary of General Government Operations, 2012-16

\begin{tabular}{|c|c|c|c|c|c|}
\hline & 2012 & 2013 & 2014 & $\begin{array}{r}2015 \\
\text { Prel. est. }\end{array}$ & $\begin{array}{r}2016 \\
\text { Latest proj. }\end{array}$ \\
\hline & \multicolumn{4}{|c|}{ (In trillions of rupiah) } & \\
\hline Total revenue and grants & 1,486 & 1,610 & 1,740 & 1,715 & 1,804 \\
\hline Taxes & 1,075 & 1,192 & 1,274 & 1,379 & 1,507 \\
\hline Taxes on income, profits, and capital gains & 465 & 506 & 546 & 602 & 725 \\
\hline Taxes on goods and services & 433 & 493 & 527 & 568 & 562 \\
\hline VAT and luxury taxes & 338 & 385 & 409 & 424 & 424 \\
\hline Excise & 95 & 108 & 118 & 145 & 139 \\
\hline Taxes on international trade and transactions & 50 & 47 & 44 & 35 & 33 \\
\hline Taxes not elsewhere classified & 127 & 145 & 156 & 173 & 186 \\
\hline Grants & 6 & 7 & 5 & 12 & 2 \\
\hline Other revenue & 406 & 411 & 461 & 324 & 295 \\
\hline Total expenditure & 1,623 & 1,822 & 1,967 & 2,002 & 2,135 \\
\hline Expense & 1,343 & 1,481 & 1,642 & 1,592 & 1,636 \\
\hline \multicolumn{6}{|l|}{ Of which: } \\
\hline Compensation of employees & 465 & 511 & 564 & 631 & 678 \\
\hline Purchases/use of goods and services & 141 & 170 & 177 & 233 & 242 \\
\hline Interest & 101 & 113 & 133 & 156 & 187 \\
\hline Energy subsidies & 306 & 310 & 342 & 119 & 95 \\
\hline Social benefit & 88 & 103 & 110 & 112 & 74 \\
\hline Net acquisition of nonfinancial assets & 280 & 341 & 324 & 410 & 499 \\
\hline Net lending/borrowing & -137 & -212 & -227 & -288 & -332 \\
\hline Net acquisition of financial assets & -1 & 7 & 35 & 126 & 72 \\
\hline Of which: policy lending & 4 & 4 & 3 & 0 & 0 \\
\hline \multirow[t]{2}{*}{ Net incurrence of liabilities } & 136 & 219 & 262 & 414 & 403 \\
\hline & \multicolumn{4}{|c|}{ (In percent of GDP) } & \\
\hline Total revenue and grants & 17.2 & 16.9 & 16.5 & 14.9 & 14.5 \\
\hline Taxes & 12.5 & 12.5 & 12.1 & 11.9 & 12.2 \\
\hline Taxes on income, profits, and capital gains & 5.4 & 5.3 & 5.2 & 5.2 & 5.8 \\
\hline Taxes on goods and services & 5.0 & 5.2 & 5.0 & 4.9 & 4.5 \\
\hline VAT and luxury taxes & 3.9 & 4.0 & 3.9 & 3.7 & 3.4 \\
\hline Excise & 1.1 & 1.1 & 1.1 & 1.3 & 1.1 \\
\hline Taxes on international trade and transactions & 0.6 & 0.5 & 0.4 & 0.3 & 0.3 \\
\hline Taxes not elsewhere classified & 1.5 & 1.5 & 1.5 & 1.5 & 1.5 \\
\hline Grants & 0.1 & 0.1 & 0.0 & 0.1 & 0.0 \\
\hline Other revenue & 4.7 & 4.3 & 4.4 & 2.8 & 2.4 \\
\hline Total expenditure & 18.8 & 19.1 & 18.6 & 17.4 & 17.2 \\
\hline Expense & 15.6 & 15.5 & 15.5 & 13.8 & 13.2 \\
\hline \multicolumn{6}{|l|}{ Of which: } \\
\hline Compensation of employees & 5.4 & 5.4 & 5.3 & 5.5 & 5.5 \\
\hline Purchases/use of goods and services & 1.6 & 1.8 & 1.7 & 2.0 & 2.0 \\
\hline Interest & 1.2 & 1.2 & 1.3 & 1.4 & 1.5 \\
\hline Energy subsidies & 3.6 & 3.2 & 3.2 & 1.0 & 0.8 \\
\hline Social benefit & 1.0 & 1.1 & 1.0 & 1.0 & 0.6 \\
\hline Net acquisition of nonfinancial assets & 3.2 & 3.6 & 3.1 & 3.6 & 4.0 \\
\hline Net lending/borrowing & -1.6 & -2.2 & -2.1 & -2.5 & -2.7 \\
\hline Net acquisition of financial assets & 0.0 & 0.1 & 0.3 & 1.1 & 0.6 \\
\hline Of which: policy lending & 0.0 & 0.0 & 0.0 & 0.0 & 0.0 \\
\hline Net incurrence of liabilities & 1.6 & 2.3 & 2.5 & 3.6 & 3.3 \\
\hline \multicolumn{6}{|l|}{ Memorandum items: } \\
\hline General government debt (In percent of GDP) & 23.0 & 24.8 & 24.7 & 26.8 & 28.0 \\
\hline Nominal GDP (In trillions of rupiah) & 8,616 & 9,546 & 10,566 & 11,541 & 12,401 \\
\hline
\end{tabular}

\section{CInternational Monetary Fund. Not for Redistribution}


Table 8. Indonesia: Monetary Survey, 2012-2017

(In trillions of rupiah, unless otherwise indicated, end of period)

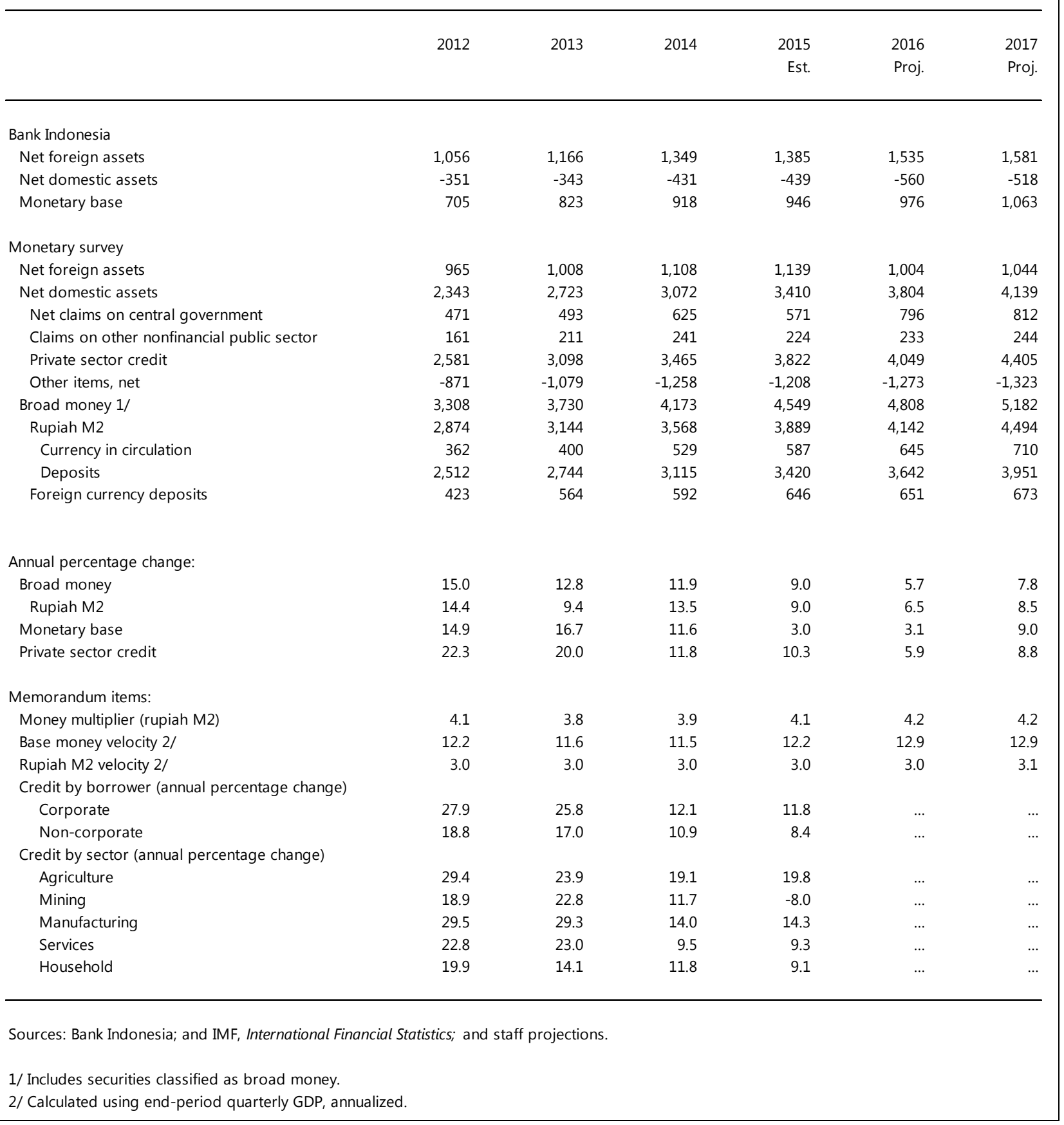


Table 9. Indonesia: Financial Soundness Indicators, 2012-2016

(In percent; unless otherwise indicated)

\begin{tabular}{|c|c|c|c|c|c|}
\hline & 2012 & 2013 & 2014 & 2015 & 2016:Q2 \\
\hline \multicolumn{6}{|l|}{ Depository institutions } \\
\hline \multicolumn{6}{|l|}{ Capital adequacy } \\
\hline Regulatory capital to risk-weighted assets & 17.3 & 19.8 & 18.7 & 21.3 & 21.2 \\
\hline Regulatory Tier-1 capital to risk-weighted assets & 15.7 & 18.3 & 17.8 & 18.8 & 19.8 \\
\hline Capital to assets & 12.2 & 12.5 & 12.8 & 13.6 & 14.7 \\
\hline Nonperforming loans, net of provisions to capital & 4.7 & 4.6 & 5.5 & 5.9 & 6.6 \\
\hline Large exposures to capital & 0.5 & 0.8 & 1.0 & 0.4 & 0.6 \\
\hline Net open position in foreign exchange to capital & 3.3 & 1.7 & 2.4 & 0.9 & 1.8 \\
\hline Gross asset position in financial derivatives to capital & 1.6 & 4.2 & 2.4 & 2.5 & 1.9 \\
\hline Gross liability position in financial derivatives to capital & 1.5 & 4.9 & 2.6 & 3.3 & 2.1 \\
\hline \multicolumn{6}{|l|}{ Asset quality } \\
\hline Nonperforming loans to total gross loans & 1.8 & 1.7 & 2.1 & 2.4 & 3.0 \\
\hline Specific provisions to nonperforming loans & 52.0 & 50.9 & 46.8 & 51.5 & 51.8 \\
\hline \multicolumn{6}{|l|}{ Earning and profitability } \\
\hline Return on assets & 3.1 & 3.1 & 2.7 & 2.2 & 2.2 \\
\hline Return on equity & 25.3 & 24.5 & 21.3 & 17.3 & 15.4 \\
\hline Interest margin to gross income & 65.0 & 68.8 & 69.0 & 70.3 & 68.4 \\
\hline Trading income to gross income & 3.2 & 3.2 & 2.7 & 2.8 & 4.0 \\
\hline Noninterest expenses to gross income & 48.8 & 49.2 & 50.3 & 50.0 & 46.3 \\
\hline Personnel expenses to noninterest expenses & 40.5 & 41.3 & 40.4 & 40.7 & 44.4 \\
\hline \multicolumn{6}{|l|}{ Liquidity and funding } \\
\hline Liquid assets to total assets & 25.7 & 23.5 & 22.9 & 23.9 & 22.1 \\
\hline Liquid assets to short-term liabilities & 36.4 & 30.5 & 33.3 & 35.0 & 32.6 \\
\hline Non-interbank loans to customer deposits & 93.2 & 99.6 & 99.2 & 100.7 & 98.2 \\
\hline \multicolumn{6}{|l|}{ Sensitivity to market risk } \\
\hline Foreign currency denominated loans to total loans & 15.2 & 17.0 & 16.3 & 15.6 & 14.2 \\
\hline Foreign currency denominated liabilities to total liabilities & 18.6 & 24.4 & 22.9 & 24.1 & 20.5 \\
\hline \multicolumn{6}{|l|}{ Nonfinancial corporates } \\
\hline \multicolumn{6}{|l|}{ Leverage } \\
\hline Total liabilities to total assets & 44.9 & 44.9 & 44.9 & 44.9 & 47.2 \\
\hline \multicolumn{6}{|l|}{ Profitability $1 /$} \\
\hline Return on assets & 17.0 & 14.8 & 14.1 & 13.9 & 14.2 \\
\hline \multicolumn{6}{|l|}{ Liquidity $1 /$} \\
\hline Current assets to current liabilities & 212.1 & 249.0 & 280.1 & 261.9 & 261.9 \\
\hline Liquid assets to current liabilities & 124.6 & 171.8 & 204.7 & 125.3 & 119.1 \\
\hline \multicolumn{6}{|l|}{ Debt servicing capacity } \\
\hline Companies with negative equity (in percent of total assets) & 1.4 & 5.7 & 5.4 & 1.2 & 0.7 \\
\hline Companies with financial distress (in percent of total debt) 2/ & 5.1 & 5.0 & 5.5 & 4.2 & 3.8 \\
\hline \multicolumn{6}{|l|}{ Households } \\
\hline Household debt (in percent of GDP) & 16.4 & 17.1 & 17.1 & 16.8 & 16.8 \\
\hline \multicolumn{6}{|l|}{ Real estate markets } \\
\hline Residential real estate prices (year-on-year percentage change) & 6.8 & 11.5 & 6.3 & 4.6 & 3.4 \\
\hline Residential real estate loans to total loans & 7.8 & 8.0 & 8.2 & 8.2 & 8.3 \\
\hline Commercial real estate loans to total loans & 6.0 & 6.3 & 6.8 & 7.4 & 8.0 \\
\hline \multicolumn{6}{|c|}{ Sources: Bloomberg Data LP.; IMF, Financial Soundness Indicators; Bank for International Settlements; and IMF staff estimates. } \\
\hline \multicolumn{6}{|l|}{ 1/ Based on capitalization-weighted average of listed companies. } \\
\hline $\begin{array}{l}\text { 2/ Companies with financial distress are those with earnings before } \\
\text { payments. }\end{array}$ & depre & nd an & $n(E B$ & an int & \\
\hline
\end{tabular}

\section{CInternational Monetary Fund. Not for Redistribution}


Table 10. Indonesia: Key Poverty and Social Indicators

Population

258.7 millions

2016

Life expectancy at birth, total

68.9 years

(2014)

Mortality rate, under 5

27.2 per 1,000 live births

(2015)

Secondary school enrollment:

$$
\text { Total }
$$

82.5 percent

Female

82.2 percent

Male

82.8 percent

GINI index

41

Income share held by highest $20 \%$

47.4 percent

Income share held by lowest $20 \%$

7.2 percent

Poverty rate

11.3 percent

$\mathrm{CO} 2$ emissions

1.9 metric tons per capita

Population with access to improved water

87.4 percent

Population with access to sanitation

60.8 percent

Human development index

0.68

Rank

110

Gender inequality index

0.49

(2014)

Rank

110

Sources: World Bank; and United Nations Development Programme. 


\begin{tabular}{|c|c|c|c|c|}
\hline \multicolumn{5}{|c|}{ Appendix I. Indonesia_Risk Assessment Matrix 1/ } \\
\hline \multicolumn{2}{|r|}{ Source of Risks } & \multirow{2}{*}{$\begin{array}{c}\text { Relative } \\
\text { Likelihood } \\
\\
\text { Medium }\end{array}$} & \multirow[b]{2}{*}{$\begin{array}{l}\text { Expected Impacts } \\
\text { High } \\
\text { Combined with uncertainties regarding the policies } \\
\text { of the incoming U.S. administration, portfolio and } \\
\text { other capital inflows could be curtailed by weaker } \\
\text { investor appetite for emerging market (EM) assets. } \\
\text { Tighter funding conditions put additional pressure } \\
\text { on the balance of payments (BOP), government } \\
\text { financing, and the financial and corporate sectors. } \\
\text { Bank funding could become constrained, raising } \\
\text { domestic borrowing costs. Rollover risks rise for } \\
\text { corporate external debt. A severe crunch in credit } \\
\text { growth or spike in lending rates could hit } \\
\text { corporate and household balance sheets (including } \\
\text { property) and reinforce negative growth dynamics } \\
\text { through asset price corrections and confidence } \\
\text { losses. }\end{array}$} & \multirow[b]{2}{*}{$\begin{array}{l}\text { Recommended Policy Responses } \\
\text { Maintain exchange rate flexibility and market- } \\
\text { determined bond yields. Preserve a sound fiscal } \\
\text { position, while allowing automatic stabilizers to } \\
\text { work in case of an extreme economic slowdown } \\
\text { and using contingent financing if market access } \\
\text { is restricted. Monetary policy tightening would } \\
\text { need to be combined with targeted measures to } \\
\text { alleviate funding pressures faced by some } \\
\text { segments of the banking system and preserve } \\
\text { financial stability to avoid reinforcing financial } \\
\text { stresses brought on by market volatility and } \\
\text { capital outflows. These should be combined } \\
\text { with heightened monitoring of corporate sector } \\
\text { vulnerabilities and firm implementation of } \\
\text { measures to encourage hedging of corporate } \\
\text { external debt. Maintain vigilance on exchange } \\
\text { rate pass-through to inflation. }\end{array}$} \\
\hline \multirow{4}{*}{ 음 } & $\begin{array}{l}\text { Tighter and more volatile } \\
\text { global financial conditions: } \\
\text { Sharp rise in risk premia with } \\
\text { flight to safety: Investors } \\
\text { withdraw from specific risk } \\
\text { asset classes as they reassess } \\
\text { underlying economic and } \\
\text { financial risks in large } \\
\text { economies, or respond to } \\
\text { unanticipated Fed tightening, } \\
\text { and increases in U.S. term } \\
\text { premia, with poor market } \\
\text { liquidity amplifying volatility. } \\
\text { Safe haven currencies surge- } \\
\text { especially the U.S. dollar- } \\
\text { creating balance sheet strains } \\
\text { for FX debtors. }\end{array}$ & & & \\
\hline & $\begin{array}{l}\text { Significant China slowdown } \\
\text { and its spillovers: A loss of } \\
\text { investor confidence, disorderly } \\
\text { corporate defaults, a sharp fall in } \\
\text { asset prices, and a quicker fading } \\
\text { of the stimulus impact. Weak } \\
\text { Chinese domestic demand } \\
\text { further suppresses commodity } \\
\text { prices, roils global financial } \\
\text { markets, and reduces global } \\
\text { growth. }\end{array}$ & $\begin{array}{l}\text { Low in the } \\
\text { short term/ } \\
\text { Medium } \\
\text { thereafter }\end{array}$ & $\begin{array}{l}\text { High } \\
\text { Lower export volume and prices (particularly those } \\
\text { of commodities) could widen the current account } \\
\text { deficit, putting FX reserves and the exchange rate } \\
\text { under pressure. The fiscal balance would } \\
\text { deteriorate on weaker resource revenues and } \\
\text { knock-on effects to domestic demand, with the } \\
\text { financial sector exposed to losses from loans to the } \\
\text { commodity sector and a broader economic } \\
\text { slowdown. Corporate profits would decline from } \\
\text { weak commodity related activities. }\end{array}$ & $\begin{array}{l}\text { Maintain exchange rate flexibility to help reduce } \\
\text { the current account deficit and limit FX reserve } \\
\text { losses. More stringent fiscal measures to contain } \\
\text { the budget deficit might be necessary if the } \\
\text { slowdown in EMs were accompanied by } \\
\text { protracted financial market volatility that } \\
\text { restricts funding. Accelerate infrastructure } \\
\text { spending and structural reforms to boost } \\
\text { productivity and employment in non-resource } \\
\text { sectors, and export diversification. }\end{array}$ \\
\hline & $\begin{array}{l}\text { Persistently lower energy } \\
\text { prices, triggered by supply } \\
\text { factors reversing more gradually } \\
\text { than expected. }\end{array}$ & $\begin{array}{c}\text { Low } \\
\text { into the } \\
\text { medium term }\end{array}$ & $\begin{array}{l}\text { Medium } \\
\text { Fiscal position would weaken further on lower oil } \\
\text { related revenues, with adverse spillovers to growth } \\
\text { if space for public investment is curbed. }\end{array}$ & $\begin{array}{l}\text { Implement upfront revenue reforms to raise } \\
\text { non-oil revenues, and accelerate structural } \\
\text { reforms to boost private investment and } \\
\text { productivity. }\end{array}$ \\
\hline & $\begin{array}{l}\text { Rise in populism and } \\
\text { nationalism in large } \\
\text { economies, leading to rising } \\
\text { trade protectionism, and } \\
\text { weighing on global growth. }\end{array}$ & High & $\begin{array}{l}\text { Low-Medium } \\
\text { Trade protectionism and reversal of globalization } \\
\text { affects external demand, while suppressing FDI } \\
\text { flows. }\end{array}$ & $\begin{array}{l}\text { Resist protectionism while deepening regional } \\
\text { trade integration and seek new opportunities to } \\
\text { enhance position in global value chains. } \\
\text { Strengthen domestic drivers of growth, notably } \\
\text { private investment. }\end{array}$ \\
\hline \multirow{2}{*}{ 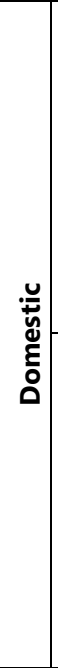 } & $\begin{array}{l}\text { Revenue shortfalls } \\
\text { constraining fiscal space, with } \\
\text { adverse spillovers to growth. } \\
\text { To keep the budget deficit within } \\
\text { the fiscal rule amidst deepening } \\
\text { revenue shortfalls and spending } \\
\text { trends, large ad-hoc cuts in } \\
\text { public spending are undertaken. }\end{array}$ & Medium & $\begin{array}{l}\text { Medium } \\
\text { The fiscal impulse supporting growth over the past } \\
\text { year would reverse abruptly, precipitating a growth } \\
\text { slowdown which could damage investor } \\
\text { confidence, curb capital inflows, raise bank NPLs, } \\
\text { increase the country risk premium, and raise costs } \\
\text { for corporate external borrowing. The consequent } \\
\text { layoffs could further weaken domestic demand. }\end{array}$ & $\begin{array}{l}\text { Implement growth-friendly revenue measures to } \\
\text { raise tax collection. Prioritize expenditures to } \\
\text { growth-critical areas and minimize disruptions } \\
\text { to project execution. Accelerate structural } \\
\text { reforms to the trade and investment regime to } \\
\text { boost productivity, private investment, and } \\
\text { exports. Assuming inflation is well anchored and } \\
\text { the external sector remains stable, ease } \\
\text { monetary policy. Supervisory actions to preserve } \\
\text { banking system soundness and close } \\
\text { monitoring of at-risk corporate borrowers. }\end{array}$ \\
\hline & $\begin{array}{l}\text { Improved sentiment on } \\
\text { reforms bolster private } \\
\text { investment. This is catalyzed by } \\
\text { progress on structural reforms, } \\
\text { the strengthening of the } \\
\text { economic cabinet, and stronger- } \\
\text { than-expected performance of } \\
\text { the tax amnesty. However, } \\
\text { domestic political risks could } \\
\text { intensify in the run-up to the } \\
\text { Jakarta election, making } \\
\text { reforms more difficult. }\end{array}$ & Medium & $\begin{array}{l}\text { Medium } \\
\text { Stronger business and investor confidence } \\
\text { translates into higher private investment activity. } \\
\text { Economic growth outperforms expectations and } \\
\text { reinforces the favorable dynamics. }\end{array}$ & $\begin{array}{l}\text { Reinforce the positive reform momentum by } \\
\text { implementing a coherent inclusive growth- } \\
\text { enhancing fiscal framework within a medium- } \\
\text { term strategy, deepen investment climate } \\
\text { reforms, and accelerate trade integration and } \\
\text { labor market reforms. }\end{array}$ \\
\hline & & & alter th & $\begin{array}{l}\text { ely to materialize in the view of IMF staff). The } \\
\text { ant to indicate a probability below } 10 \text { percent, } \\
\text { cent). The RAM reflects staff views on the } \\
\text { risks may interact and materialize jointly. } \\
\text { ectively. }\end{array}$ \\
\hline
\end{tabular}




\begin{tabular}{|c|c|c|}
\hline & Indonesia & Overall Assessment \\
\hline $\begin{array}{l}\text { Foreign asset and } \\
\text { liability position } \\
\text { and trajectory }\end{array}$ & $\begin{array}{l}\text { Background. At end-June 2016, Indonesia's net international investment position (NIP) stood at - } 46 \text { percent of GDP, } \\
\text { compared to -431/4 percent of GDP at end-2015. A majority of the widening in the first half of } 2016 \text { was due to strong net } \\
\text { portfolio inflows (mainly government debt). At end-June 2016, gross external liabilities stood at } 71 \text { percent of GDP. } \\
\text { Indonesia's gross external debt was moderate at } 353 / 4 \text { percent of GDP, with about } 61 / 2 \text { percent of GDP denominated in rupiah } \\
\text { at end-September } 2016 \text {. } \\
\text { Assessment. The level and composition of the NIIP and gross external debt indicate that Indonesia's external position is } \\
\text { sustainable, but nonresident holdings of rupiah denominated government bonds, with a share of } 37 \text { percent at } \\
\text { end-November, could be affected by global volatility. Private external debt growth is expected to slow on the implementation } \\
\text { of BI's FX hedging regulations and expected tightening of global financial conditions. }\end{array}$ & \multirow{5}{*}{$\begin{array}{l}\text { Overall Assessment } \\
\text { In 2016, Indonesia's external } \\
\text { position is assessed to be broadly } \\
\text { consistent with medium-term } \\
\text { fundamentals and desirable } \\
\text { policy settings. Lower commodity } \\
\text { prices and weak trading partner } \\
\text { demand for commodity exports } \\
\text { have been compensated by } \\
\text { import compression. External } \\
\text { financing appears sustainable, } \\
\text { but large share of new } \\
\text { borrowing makes it vulnerable to } \\
\text { domestic and external shocks. } \\
\text { Potential Policy Responses } \\
\text { Monetary policy should continue } \\
\text { to focus on containing inflation } \\
\text { within Bank Indonesia's target } \\
\text { band. Fiscal policy can help } \\
\text { support external adjustment and } \\
\text { contain vulnerability to funding } \\
\text { pressures by aiming for a small } \\
\text { primary deficit over the medium } \\
\text { term. This could be led by } \\
\text { reforms aimed at mobilizing } \\
\text { revenues in a growth-friendly } \\
\text { way to provide space for health } \\
\text { and infrastructure spending to } \\
\text { help ease supply bottlenecks and } \\
\text { bolster exports over the medium } \\
\text { term. Continued flexibility of the } \\
\text { exchange rate and use of } \\
\text { market-determined interest rates } \\
\text { would also help facilitate } \\
\text { adjustment and absorb shocks. } \\
\text { Easing trade and investment } \\
\text { restrictions, deepening financial } \\
\text { markets, and improving labor } \\
\text { markets would help strengthen } \\
\text { overall competitiveness over the } \\
\text { medium term. }\end{array}$} \\
\hline Current account & $\begin{array}{l}\text { Background. Indonesia's current account deficit is projected at } 2.0 \text { percent of GDP in } 2016 \text {, as the continued decline in } \\
\text { commodity exports could be largely compensated by less imports due to low oil prices and cyclical weakness in investment. } \\
\text { The contraction of exports and imports is moderating, as commodity prices have bottomed out. Over the medium term, a } \\
\text { moderate increase in the current account deficit is expected from a rise in capital goods and raw material imports tied to } \\
\text { infrastructure investment and a pickup in domestic demand. A gradual increase in manufacturing exports, stronger demand } \\
\text { from trading partners, and relatively low projected world oil prices should help limit the increase in the CA deficit. External } \\
\text { adjustment would be supported over time by continued exchange rate flexibility and a prudent monetary and fiscal stance, in } \\
\text { keeping with a moderate increase in domestic saving. } \\
\text { Assessment. The EBA CA model suggests a gap of } 0.2 \text { percent of GDP for } 2016 \text { (based on an estimated cyclically-adjusted CA } \\
\text { balance of }-1.4 \text { percent of GDP and a norm of - }-1.6 \text { percent of GDP), same as the gap of } 0.2 \text { percent for } 2015 \text {. Taking into } \\
\text { account the uncertainties of the EBA-regression estimates and Indonesia's investment needs, staff assesses that a norm of - } \\
0.6 \text { percent to - } 2.6 \text { percent of GDP is appropriate. }{ }^{1 /} \text { This suggests a CA gap range of about }-0.8 \text { percent to } 1.2 \text { percent of GDP } \\
\text { for 2016, which reflects domestic gaps including in social spending and policy gaps in partner countries (particularly fiscal } \\
\text { deficits). }\end{array}$ & \\
\hline $\begin{array}{l}\text { Real exchange } \\
\text { rate }\end{array}$ & $\begin{array}{l}\text { Background. Compared to the } 2015 \text { average, the REER appreciated by } 3.1 \text { percent in the first ten months of } 2016 \text {. } \\
\text { Assessment. EBA index and level REER results suggest the REER gap to be about }-3.4 \text { percent to } 3.2 \text { percent, respectively, in } \\
\text { line with staff's REER gap assessment in the range of }-6 \text { percent to } 4 \text { percent in } 2016 \text { based on the CA assessment. }\end{array}$ & \\
\hline $\begin{array}{l}\text { Capital and } \\
\text { financial } \\
\text { accounts: } \\
\text { flows and policy } \\
\text { measures }\end{array}$ & $\begin{array}{l}\text { Background. Indonesia's gross external financing requirement is expected to be about } 9.2 \text { percent of GDP in } 2016 \text {, with } \\
\text { amortization at about } 6 \text { percent of GDP. Net FDI and new borrowing are projected at } 1.5 \text { percent and } 7.6 \text { percent of GDP, } \\
\text { respectively. } \\
\text { Assessment. Net and gross financial flows have been steady since the global financial crisis despite some short periods of } \\
\text { volatility. The narrower current account deficit and strengthened policy framework including exchange rate flexibility since } \\
\text { mid-2013 have also helped reduce capital flow volatility. For } 2016 \text {, financial flows have been supported by attractive bond } \\
\text { yields and assets repatriation related to the tax amnesty but could become weaker or reverse in the event of large domestic } \\
\text { or external shocks as seen in November } 2016 \text {. Continued strong policies focused on strengthening the fiscal position, } \\
\text { keeping inflation in check, and easing supply bottlenecks would help sustain capital inflows in the medium term. }\end{array}$ & \\
\hline $\begin{array}{l}\text { FX intervention } \\
\text { and reserves level }\end{array}$ & $\begin{array}{l}\text { Background. Since mid-2013, Indonesia has had a more flexible exchange rate policy framework. Its floating regime has } \\
\text { better facilitated adjustments in exchange rates to market conditions. At end-November } 2016 \text {, reserves were US } \$ 111.5 \text { billion } \\
\text { (equal to } 122 \text { percent of IMF's reserve adequacy metric-and about } 8 \text { months of prospective imports of goods and services). } \\
\text { In addition, the authorities have in place contingencies and swap lines amounting to about US } \$ 83 \text { billion. } \\
\text { Assessment. Volatile capital flows could cause reserves to decline significantly. While the composite metric may not } \\
\text { adequately account for commodity price volatility, the current level of reserves should be sufficient to absorb most shocks, } \\
\text { with predetermined drains also manageable. Intervention should aim primarily at preventing disorderly market conditions, } \\
\text { while allowing the exchange rate to adjust to external shocks. }\end{array}$ & \\
\hline $\begin{array}{l}\text { Technical } \\
\text { Background } \\
\text { Notes }\end{array}$ & $\begin{array}{l}\text { 1/ A range of }+/-1 \text { percent is added to reflect the fact that the EBA-regression estimates are subject to high uncertainty given } \\
\text { the large residual. }\end{array}$ & \\
\hline
\end{tabular}




\section{Appendix III. Indonesia-Debt Sustainability Analysis}

Indonesia's external debt remains at a moderate level and is projected to be sustainable over the medium-term. Growth in private external debt is expected to remain slow, partly contained by the BI's FX hedging regulations and less favorable global financial conditions. Public debt remains low, but contingent liabilities arising from borrowing by state-owned enterprises (SOEs) and public-private partnerships (PPPs) in infrastructure development may pose some fiscal risk, which should continue to be carefully monitored. Reliance on foreign investors remains sizable, which could leave Indonesia susceptible to external shocks and funding stops.

\section{External Debt Sustainability}

Indonesia's external debt-to-GDP ratio has stabilized after a steady increase in recent years, and total external debt remains at a moderate level. As a share of GDP, external debt was 36 percent at end-2015, up from 25 percent at end-2011, reflecting a rise in general government borrowing, through internationally issued bonds and holdings of nonresidents of domestic bonds, and private external borrowing, mainly through loans and debt securities, including by SOEs. As growth in external borrowing has slowed and pressures on the exchange rate have reduced, external debt is expected to decline to 34 percent of GDP at end-2016 (Figure 1 and Table 1).

Looking ahead, the external debt is projected to gradually decline in the medium term. Under the baseline, debt would decline to 253/4 percent by end-2021 in line with favorable real GDP growth and a slower buildup in nonbank private sector debt due to BI's FX hedging requirements and less favorable global financial conditions. Public external debt is expected to remain at low levels, as external borrowing of the public sector is tightly regulated by an inter-ministerial committee. Real GDP growth is projected to average about 51/2 percent over the medium term.

As in the last Article IV, external sustainability is robust to interest rate and GDP shocks, but is more sensitive to current account and exchange rate shocks (Figure 2). A further deterioration in the current account balance from the current level would cause the external debt ratio to rise moderately (a one-standard deviation shock would raise the external debt to GDP ratio to 303/4 percent by 2021). Exchange rate depreciation would have the largest impact-a 30 percent depreciation in 2017 would raise the external debt-to-GDP ratio to about 461/4 percent in 2017 followed by a gradual decline to 37 percent of GDP by 2021.

\section{Public Debt Sustainability}

Public sector debt remains low in Indonesia. General government debt as a percent of GDP declined steadily from 87 percent in 2000 to 27 percent in 2015, owing to a prudent fiscal stance, which has been anchored by the fiscal rule since 2003. The rule caps the annual general government deficit at 3 percent of GDP. The debt dynamics have been also favorable, with strong GDP growth and moderate real interest rates. In 2016, the debt-to-GDP ratio is estimated to increase to 28 percent of GDP (from 26.8 percent of GDP in 2015), reflecting slightly larger primary deficit than in 
the past and higher real interest rate. At the same time, foreign-currency denominated debt has fallen to less than half of total public sector debt, as issuance in the domestic rupiah bond market has grown and attracted strong foreign interests. Notwithstanding, dependence on foreign investors remains sizable, with nonresidents holding about 60 percent of general government debt. Moreover, the share of foreign ownership of rupiah-denominated government bonds rose from about 20 percent in 2009 to about 37 percent as of end-November 2016.

\section{Under the baseline scenario, public sector debt is expected to increase gradually over the} medium term (Figure 3). The baseline envisages the general government deficit to remain constant at 2.5 percent of GDP over the medium term, resulting in the primary deficit at $3 / 4$ percent of GDP through 2021. Favorable debt dynamics, with a negative interest rate-growth differential (about 5 percent over the medium term), would limit the increase in the debt-to-GDP ratio, which is expected to reach 29.4 percent by 2021 . Gross financing needs are also expected to remain at around 5 percent of GDP over the medium term.

Public debt dynamics are robust to both standard shocks and stress tests (Figures 4 and 5). Even under the most severe scenario with a combined macro-fiscal shock, total government debt would stabilize at 35 percent of GDP or 250 percent of revenue, with gross financing needs below 7 percent of GDP. Nevertheless, fiscal risks, in particular those arising from expanding balance sheets of key SOEs and PPPs, will need to be managed carefully. These modalities of investment are tasked with the bulk of infrastructure development, and strengthening public investment management will limit contingent liabilities arising from such entities and activities. 
Figure 1. Indonesia: External Debt and Debt Service

Indonesia: External Debt Projections, 2013-21

(In percent of GDP)

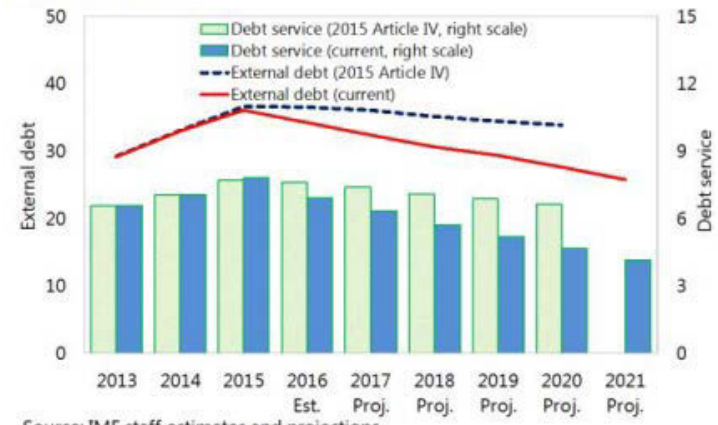

Source: IMF staff estimates and projections.

Indonesia: Composition of External Debt, 2013-21

(In percent of GDP)

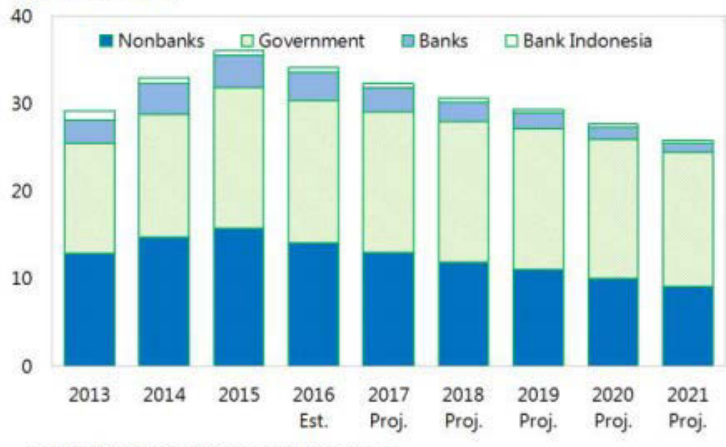

Source: IMF staff estimates and projections.
Indonesia: Debt Financing, 2013-21

(In percent of the gross external financing requirement)

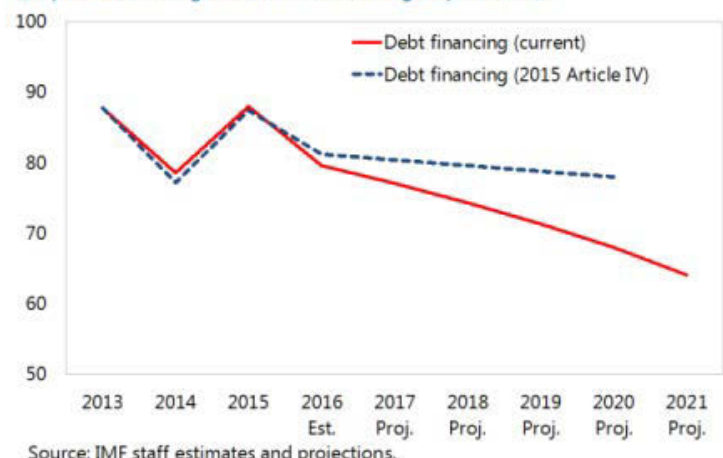

Source: IMF staff estimates and projections.

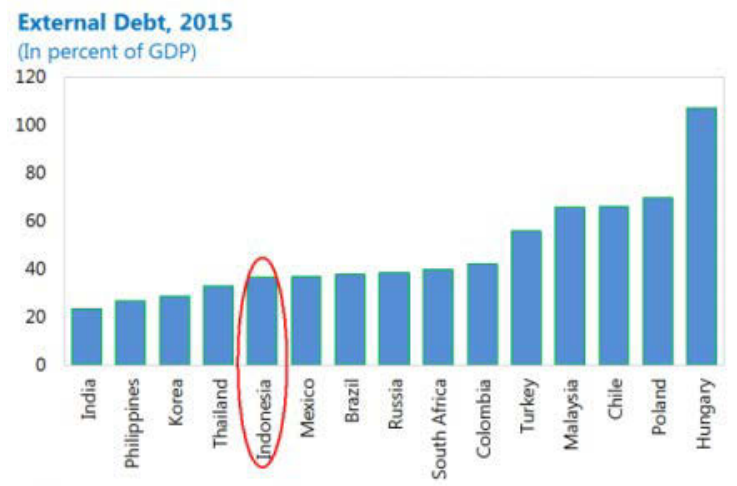

Source: IMF, World Economic Outlook. 
Figure 2. Indonesia: External Debt Sustainability: Bound Tests 1/ 2/

(External debt in percent of GDP)

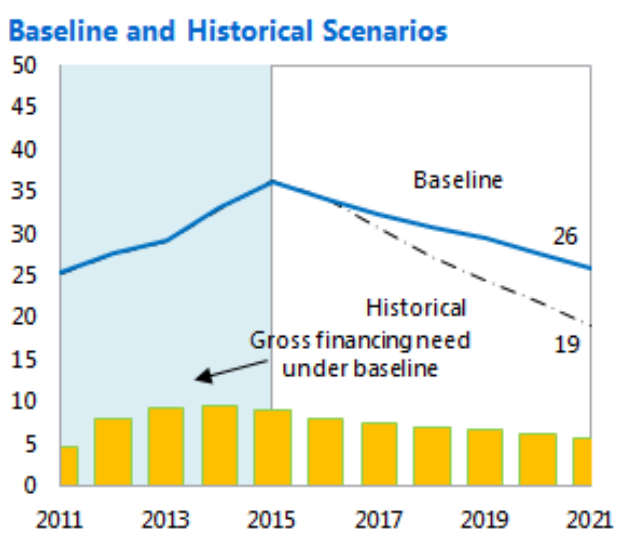

Growth Shock

(In percent per year)

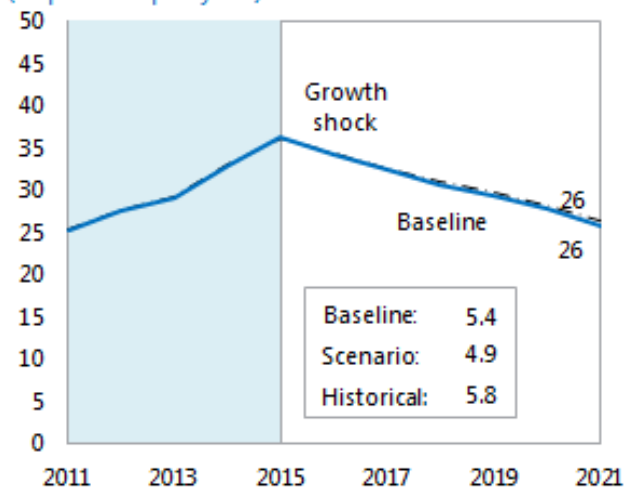

Combined Shock 3/

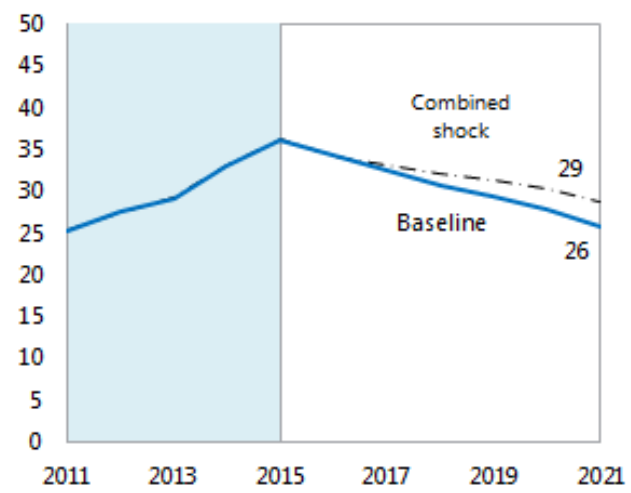

Interest Rate Shock (in percent)

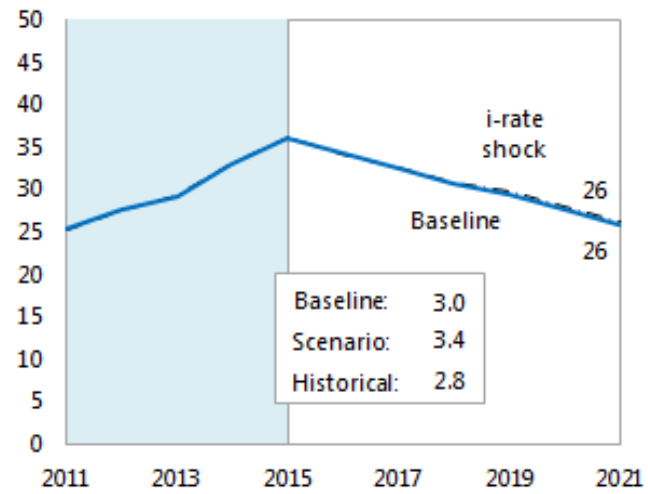

Noninterest Current Account Shock

(In percent of GDP)

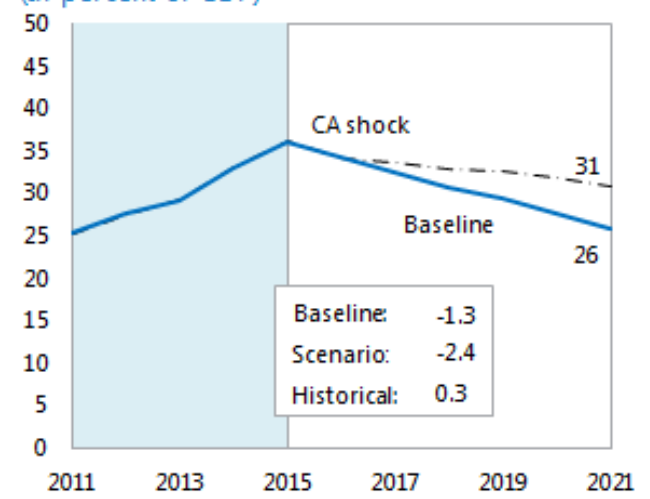

Real Depreciation Shock 4/

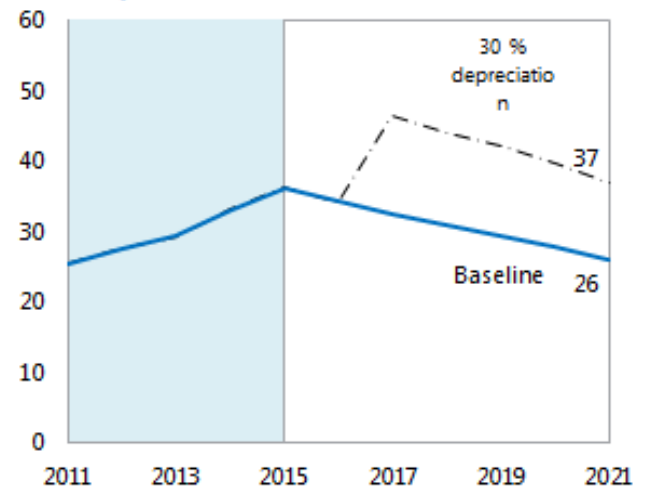

Sources: International Monetary Fund, Country desk data; and staff estimates.

1/ Shaded areas represent actual data. Individual shocks are permanent one-half standard deviation shocks. Figures in the boxes represent average projections for the respective variables in the baseline and scenario being presented. Tenyear historical average for the variable is also shown.

2/ For historical scenarios, the historical averages are calculated over the ten-year period, and the information is used to project debt dynamics five years ahead.

3/ Permanent 1/4 standard deviation shocks applied to real interest rate, growth rate, and current account balance. 4/ One-time real depreciation of 30 percent occurs in 2017. 
Table 1. Indonesia: External Debt Sustainability Framework, 2011-2021

(In percent of GDP, unless otherwise indicated)

\begin{tabular}{|c|c|c|c|c|c|c|c|c|c|c|c|c|c|c|}
\hline & \multicolumn{5}{|c|}{ Actual } & & & \multicolumn{7}{|c|}{ Projections } \\
\hline & 2011 & 2012 & 2013 & 2014 & 2015 & & & 2016 & 2017 & 2018 & 2019 & 2020 & 2021 & $\begin{array}{l}\text { Debt-stabilizing } \\
\text { non-interest } \\
\text { current account 6/ }\end{array}$ \\
\hline 1 Baseline: External debt & 25.2 & 27.5 & 29.1 & 32.9 & 36.1 & & & 34.1 & 32.3 & 30.6 & 29.3 & 27.7 & 25.8 & -3.9 \\
\hline 2 Change in external debt & -1.6 & 2.2 & 1.6 & 3.8 & 3.2 & & & -2.0 & -1.8 & -1.7 & -1.3 & -1.6 & -1.9 & \\
\hline 3 Identified external debt-creating flows $(4+8+9)$ & -5.5 & 0.1 & 1.9 & 1.5 & 1.7 & & & -1.3 & -1.3 & -1.2 & -1.2 & -1.2 & -1.1 & \\
\hline 4 Current account deficit, excluding interest payments & -0.7 & 2.1 & 2.6 & 2.4 & 1.2 & & & 1.0 & 1.0 & 1.2 & 1.3 & 1.4 & 1.5 & \\
\hline Deficit in balance of goods and services & -45.0 & -46.1 & -45.5 & -45.0 & -39.1 & & & -34.7 & -34.2 & -32.9 & -32.3 & -31.5 & -30.4 & \\
\hline Exports & 23.9 & 23.0 & 22.4 & 22.3 & 19.9 & & & 17.8 & 17.5 & 16.8 & 16.5 & 16.0 & 15.4 & \\
\hline Imports & -21.2 & -23.2 & -23.1 & -22.7 & -19.3 & & & -16.9 & -16.7 & -16.1 & -15.8 & -15.5 & -15.0 & \\
\hline 8 Net nondebt creating capital inflows (negative) & -1.3 & -1.7 & -1.1 & -2.0 & -1.1 & & & -1.6 & -1.7 & -1.8 & -1.9 & -1.9 & -2.0 & \\
\hline $9 \quad$ Automatic debt dynamics $1 /$ & -3.5 & -0.3 & 0.4 & 1.1 & 1.6 & & & -0.7 & -0.7 & -0.7 & -0.7 & -0.7 & -0.6 & \\
\hline Contribution from nominal interest rate & 0.5 & 0.6 & 0.6 & 0.7 & 0.9 & & & 0.9 & 0.9 & 0.9 & 0.8 & 0.8 & 0.7 & \\
\hline Contribution from real GDP growth & -1.4 & -1.5 & -1.5 & -1.5 & -1.6 & & & -1.7 & -1.6 & -1.6 & -1.5 & -1.5 & -1.4 & \\
\hline Contribution from price and exchange rate changes $2 /$ & -2.6 & 0.6 & 1.3 & 1.9 & 2.3 & & & $\ldots$ & $\ldots$ & $\ldots$ & $\ldots$ & $\ldots$ & $\ldots$ & \\
\hline 3 Residual, including change in gross foreign assets (2-3) 3 / & 3.9 & 2.1 & -0.2 & 2.4 & 1.5 & & & -0.6 & -0.5 & -0.4 & -0.1 & -0.4 & -0.7 & \\
\hline External debt-to-exports ratio (in percent) & 105.8 & 119.6 & 129.8 & 147.5 & 181.7 & & & 192.0 & 185.0 & 182.2 & 177.8 & 172.6 & 167.2 & \\
\hline $\begin{array}{l}\text { Gross external financing need (in billions of U.S. dollars) } 4 \text { / } \\
\text { In percent of GDP }\end{array}$ & $\begin{array}{r}41.2 \\
4.6\end{array}$ & $\begin{array}{r}71.2 \\
7.7\end{array}$ & $\begin{array}{r}83.8 \\
9.2\end{array}$ & $\begin{array}{r}83.8 \\
9.4\end{array}$ & $\begin{array}{r}76.8 \\
8.9\end{array}$ & & & $\begin{array}{r}73.6 \\
7.9\end{array}$ & $\begin{array}{r}74.1 \\
7.4\end{array}$ & $\begin{array}{r}76.5 \\
6.9\end{array}$ & $\begin{array}{r}78.0 \\
6.5\end{array}$ & $\begin{array}{r}80.3 \\
6.1\end{array}$ & $\begin{array}{r}83.1 \\
5.7\end{array}$ & \\
\hline $\begin{array}{l}\text { Scenario with key variables at their historical averages 5/ } \\
\text { Key Macroeconomic Assumptions Underlying Baseline }\end{array}$ & & & & & & $\begin{array}{l}\text { 10-Year } \\
\text { Historical } \\
\text { Average }\end{array}$ & $\begin{array}{l}\text { 10-Year } \\
\text { Standard } \\
\text { Deviation }\end{array}$ & 34.1 & 30.4 & 27.3 & 24.4 & 21.7 & 19.1 & -2.6 \\
\hline Real GDP growth (in percent) & 6.2 & 6.0 & 5.6 & 5.0 & 4.8 & 5.8 & 0.8 & 5.0 & 5.1 & 5.3 & 5.4 & 5.5 & 5.5 & \\
\hline GDP deflator in U.S. dollars (change in percent) & 11.3 & -2.9 & -5.7 & -7.3 & -8.0 & 5.2 & 11.7 & 3.1 & 3.1 & 4.0 & 3.1 & 4.4 & 5.5 & \\
\hline Nominal external interest rate (in percent) & 2.2 & 2.3 & 2.0 & 2.4 & 2.6 & 2.8 & 0.7 & 2.8 & 3.0 & 3.0 & 3.0 & 3.0 & 3.0 & \\
\hline Growth of exports (U.S. dollar terms, in percent) & 27.8 & -0.9 & -2.8 & -3.0 & -14.2 & 6.4 & 15.7 & -3.1 & 6.3 & 5.5 & 6.5 & 7.0 & 7.1 & \\
\hline Growth of imports (U.S. dollar terms, in percent) & 30.1 & 12.7 & -0.8 & -4.5 & -18.0 & 7.8 & 19.8 & -5.0 & 7.0 & 5.5 & 6.7 & 7.7 & 7.8 & \\
\hline Current account balance, excluding interest payments & 0.7 & -2.1 & -2.6 & -2.4 & -1.2 & 0.3 & 2.3 & -1.0 & -1.0 & -1.2 & -1.3 & -1.4 & -1.5 & \\
\hline Net nondebt creating capital inflows & 1.3 & 1.7 & 1.1 & 2.0 & 1.1 & 1.2 & 0.5 & 1.6 & 1.7 & 1.8 & 1.9 & 1.9 & 2.0 & \\
\hline
\end{tabular}

1/ Derived as $[r-g-r(1+g)+$ ea $(1+r)] /(1+g+r+g r)$ times previous period debt stock, with $r=$ nominal effective interest rate on external debt; $r=$ change in domestic GDP deflator in U.S. dollar terms, $g=$ real GDP growth rate, $\mathrm{e}=$ nominal appreciation (increase in dollar value of domestic currency), and $\mathrm{a}=$ share of domestic-currency denominated debt in total external debt.

$2 /$ The contribution from price and exchange rate changes is defined as $[-r(1+g)+e a(1+r)] /(1+g+r+g r)$ times previous period debt stock. $r$ increases with an appreciating domestic currency (e $>0)$ and rising inflation (based on GDP deflator).

3/ For projection, line includes the impact of price and exchange rate changes.

4/ Defined as current account deficit, plus amortization on medium- and long-term debt, plus short-term debt at end of previous period.

5/ The key variables include real GDP growth; nominal interest rate; dollar deflator growth; and both non-interest current account and non-debt inflows in percent of GDP.

6/ Long-run, constant balance that stabilizes the debt ratio assuming that key variables (real GDP growth, nominal interest rate, dollar deflator growth, and non-debt inflows in percent of GDP) remain at their levels of the last projection year. 
Figure 3. Indonesia: Public Sector Debt Sustainability Analysis (DSA)—Baseline Scenario

(In percent of GDP unless otherwise indicated)

\begin{tabular}{|c|c|c|c|c|c|c|c|c|c|c|c|c|}
\hline \multirow[b]{4}{*}{ Nominal gross public debt } & \multicolumn{9}{|c|}{ Debt, Economic and Market Indicators ${ }^{1 /}$} & & & \\
\hline & \multicolumn{3}{|c|}{ Actual } & \multicolumn{6}{|c|}{ Projections } & \multirow{2}{*}{\multicolumn{3}{|c|}{$\begin{array}{l}\text { As of December 06, } 2016 \\
\text { Sovereign Spreads }\end{array}$}} \\
\hline & $2005-2013$ & 2014 & 2015 & 2016 & 2017 & 2018 & 2019 & 2020 & 2021 & & & \\
\hline & 29.2 & 24.7 & 26.8 & 28.0 & 28.4 & 28.7 & 29.2 & 29.2 & 29.4 & EMBIG $(b$ & $3 /$ & 241 \\
\hline Public gross financing needs & 2.9 & 4.4 & 4.2 & 4.6 & 4.3 & 4.8 & 4.7 & 4.3 & 5.2 & $5 Y \operatorname{CDS}(\mathfrak{k}$ & & 166 \\
\hline Real GDP growth (in percent) & 6.0 & 5.0 & 4.8 & 5.0 & 5.1 & 5.3 & 5.4 & 5.5 & 5.5 & Ratings & Foreign & Local \\
\hline Inflation (GDP deflator, in percent) & 9.6 & 5.4 & 4.2 & 2.4 & 4.4 & 4.5 & 4.3 & 4.1 & 4.0 & Moody's & Baa3 & Baa3 \\
\hline Nominal GDP growth (in percent) & 16.2 & 10.7 & 9.2 & 7.5 & 9.8 & 10.0 & 9.9 & 9.8 & 9.7 & S\&Ps & $\mathrm{BB}+$ & $\mathrm{BB}+$ \\
\hline Effective interest rate (in percent) ${ }^{4 /}$ & 5.8 & 5.6 & 6.0 & 6.0 & 6.3 & 6.4 & 6.5 & 6.5 & 6.5 & Fitch & BBB- & BBB- \\
\hline
\end{tabular}

Contribution to Changes in Public Debt

\begin{tabular}{|c|c|c|c|c|c|c|c|c|c|c|c|}
\hline & \multicolumn{3}{|c|}{ Actual } & \multicolumn{8}{|c|}{ Projections } \\
\hline & $2005-2013$ & 2014 & 2015 & 2016 & 2017 & 2018 & 2019 & 2020 & 2021 & cumulative & debt-stabilizing \\
\hline Change in gross public sector debt & -2.9 & -0.2 & 2.2 & 1.2 & 0.3 & 0.3 & 0.5 & 0.0 & 0.2 & 2.6 & primary \\
\hline Identified debt-creating flows & -3.4 & 0.1 & 2.4 & 0.9 & 0.3 & 0.3 & 0.3 & 0.3 & 0.2 & 2.4 & balance $^{\text {9/ }}$ \\
\hline Primary deficit & -0.7 & 0.9 & 1.1 & 1.2 & 0.8 & 0.8 & 0.8 & 0.8 & 0.8 & 5.1 & -0.5 \\
\hline Primary (noninterest) revenue and gr & 17.3 & 16.5 & 14.9 & 14.5 & 14.3 & 14.2 & 14.2 & 14.2 & 14.3 & 85.7 & \\
\hline Primary (noninterest) expenditure & 16.6 & 17.3 & 16.0 & 15.6 & 15.1 & 15.0 & 15.0 & 15.0 & 15.0 & 90.8 & \\
\hline Automatic debt dynamics ${ }^{5 /}$ & -2.7 & -0.9 & 0.3 & -0.4 & -0.9 & -0.9 & -0.9 & -0.9 & -0.8 & -4.8 & \\
\hline Interest rate/growth differential ${ }^{6 /}$ & -3.1 & -1.1 & -0.7 & -0.4 & -0.9 & -0.9 & -0.9 & -0.9 & -0.8 & -4.8 & \\
\hline Of which: real interest rate & -1.4 & 0.0 & 0.3 & 0.9 & 0.4 & 0.4 & 0.5 & 0.6 & 0.6 & 3.5 & \\
\hline Of which: real GDP growth & -1.6 & -1.1 & -1.1 & -1.2 & -1.3 & -1.4 & -1.4 & -1.5 & -1.5 & -8.2 & \\
\hline Exchange rate depreciation $7 /$ & 0.4 & 0.2 & 1.1 & $\ldots$ & $\ldots$ & $\ldots$ & $\ldots$ & $\ldots$ & $\ldots$ & $\ldots$ & \\
\hline Other identified debt-creating flows & 0.1 & 0.1 & 1.0 & 0.1 & 0.5 & 0.4 & 0.4 & 0.3 & 0.3 & 2.1 & \\
\hline Please specify (1) (e.g., drawdown of & 0.0 & 0.0 & 0.0 & 0.0 & 0.0 & 0.0 & 0.0 & 0.0 & 0.0 & 0.0 & \\
\hline Contingent liabilities & 0.0 & 0.0 & 0.0 & 0.0 & 0.0 & 0.0 & 0.0 & 0.0 & 0.0 & 0.0 & \\
\hline Please specify (2) (e.g., ESM and Eurc & 0.1 & 0.1 & 1.0 & 0.1 & 0.5 & 0.4 & 0.4 & 0.3 & 0.3 & 2.1 & \\
\hline Residual, including asset changes ${ }^{8 /}$ & 0.4 & -0.2 & -0.3 & 0.3 & 0.0 & 0.0 & 0.2 & -0.3 & 0.0 & 0.1 & \\
\hline
\end{tabular}

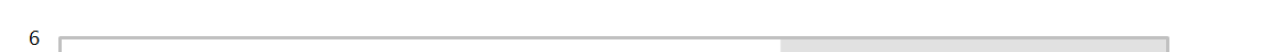

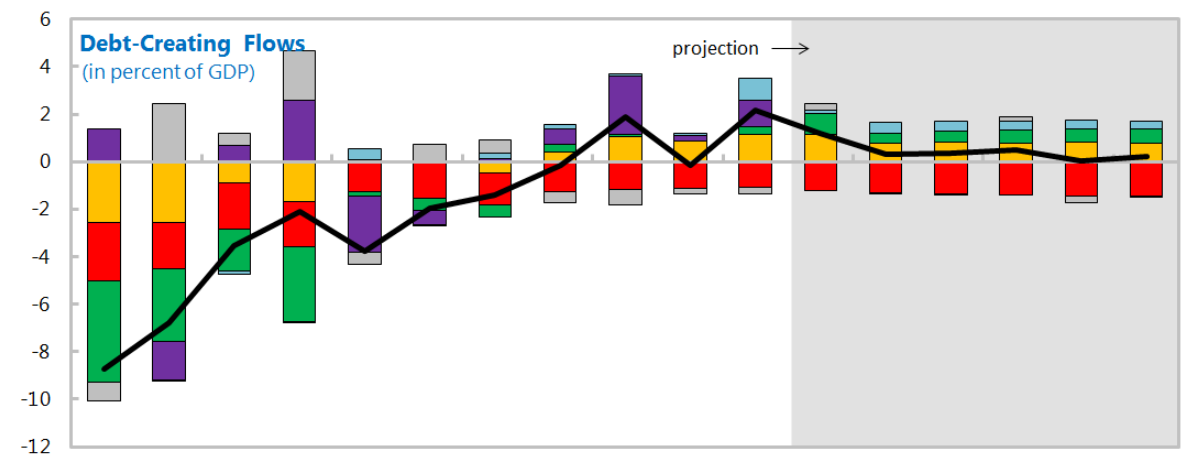

$\begin{array}{lllllllllllllllll}2005 & 2006 & 2007 & 2008 & 2009 & 2010 & 2011 & 2012 & 2013 & 2014 & 2015 & 2016 & 2017 & 2018 & 2019 & 2020 & 2021\end{array}$

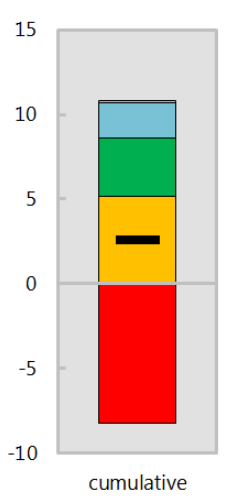

$\square$ Primary deficit $\square$ Real GDP growth $\square$ Real interest rate Exchange rate depreciation

$\square$ Other debt-creating flows $\quad \square$ Residual Change in gross public sector debt

Source: IMF staff.

$1 /$ Public sector is defined as general government.

2/ Based on available data.

3/ EMBIG.

4/ Defined as interest payments divided by debt stock (excluding guarantees) at the end of previous year.

5/ Derived as $[(r-\pi(1+g)-g+a e(1+r)] /(1+g+\pi+g \pi))$ times previous period debt ratio, with $r=$ interest rate; $\pi=$ growth rate of GDP deflator; $g=$ real GDP growth rate:

$\mathrm{a}=$ share of foreign-currency denominated debt; and $\mathrm{e}=$ nominal exchange rate depreciation (measured by increase in local currency value of U.S. dollar).

6/ The real interest rate contribution is derived from the numerator in footnote 5 as $r-\pi(1+g)$ and the real growth contribution as $-g$.

7/ The exchange rate contribution is derived from the numerator in footnote 5 as ae( $1+r)$.

$8 /$ Includes asset changes and interest revenues (if any). For projections, includes exchange rate changes during the projection period.

9/ Assumes that key variables (real GDP growth, real interest rate, and other identified debt-creating flows) remain at the level of the last projection year.

CInternational Monetary Fund. Not for Redistribution 
Figure 4. Indonesia: Public DSA—Composition of Public Debt and Alternative Scenarios

\section{Composition of Public Debt}

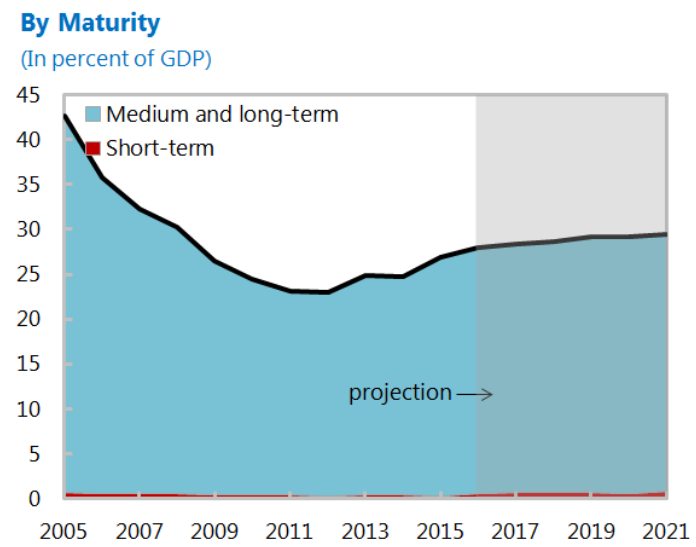

\section{By Currency}

(In percent of GDP)

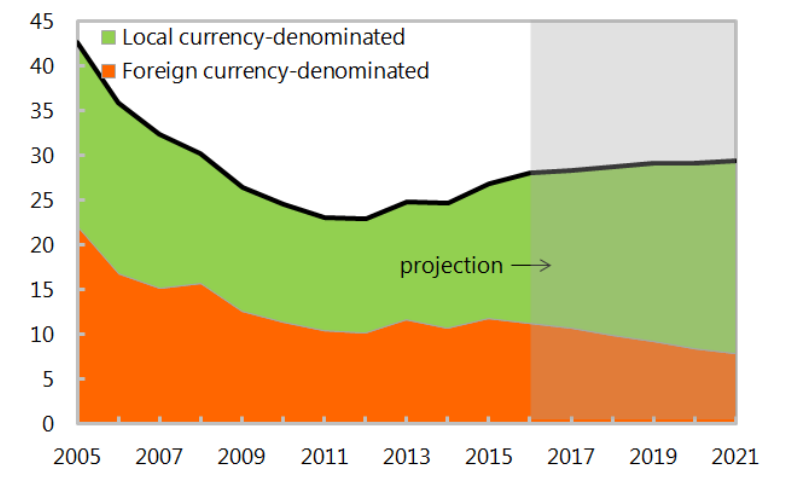

Alternative Scenarios

Baseline

--- Constant Primary Balance

Gross Nominal Public Debt

\section{(in percent of GDP)}

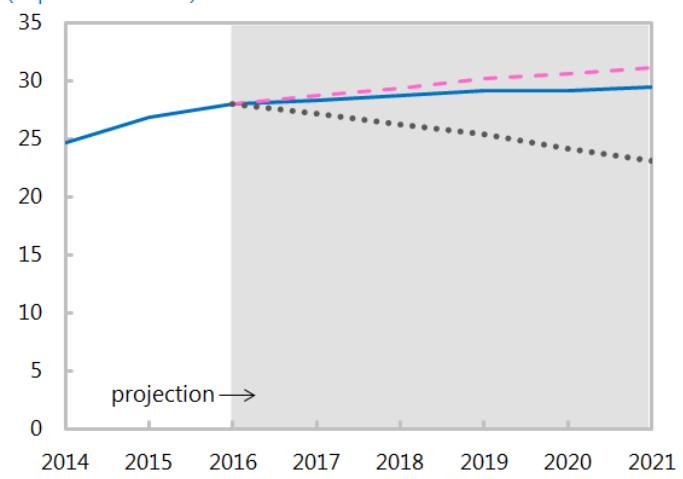

Public Gross Financing Needs

(in percent of GDP)

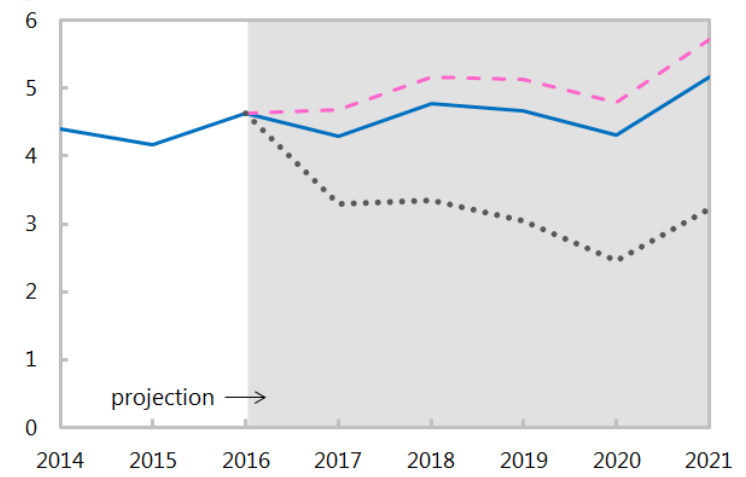

Underlying Assumptions

(In percent)

\begin{tabular}{lrrrrrr}
\cline { 2 - 7 } Baseline Scenario & 2016 & 2017 & 2018 & 2019 & 2020 & 2021 \\
\cline { 2 - 7 }$\quad$ Real GDP growth & 5.0 & 5.1 & 5.3 & 5.4 & 5.5 & 5.5 \\
Inflation & 2.4 & 4.4 & 4.5 & 4.3 & 4.1 & 4.0 \\
Primary balance & -1.2 & -0.8 & -0.8 & -0.8 & -0.8 & -0.8 \\
$\quad$ Effective interest rate & 6.0 & 6.3 & 6.4 & 6.5 & 6.5 & 6.5 \\
Constant Primary Balance Scenario & & & & & \\
$\quad$ Real GDP growth & 5.0 & 5.1 & 5.3 & 5.4 & 5.5 & 5.5 \\
Inflation & 2.4 & 4.4 & 4.5 & 4.3 & 4.1 & 4.0 \\
Primary balance & -1.2 & -1.2 & -1.2 & -1.2 & -1.2 & -1.2 \\
Effective interest rate & 6.0 & 6.3 & 6.4 & 6.5 & 6.5 & 6.5 \\
\hline
\end{tabular}

\begin{tabular}{lrrrrrr}
\cline { 2 - 7 } Historical Scenario & 2016 & 2017 & 2018 & 2019 & 2020 & 2021 \\
\cline { 2 - 7 }$\quad$ Real GDP growth & 5.0 & 5.8 & 5.8 & 5.8 & 5.8 & 5.8 \\
Inflation & 2.4 & 4.4 & 4.5 & 4.3 & 4.1 & 4.0 \\
Primary balance & -1.2 & 0.2 & 0.2 & 0.2 & 0.2 & 0.2 \\
Effective interest rate & 6.0 & 6.3 & 5.9 & 5.4 & 5.0 & 4.7 \\
& & & & & & \\
& & & & & & \\
\end{tabular}

Source: IMF staff. 


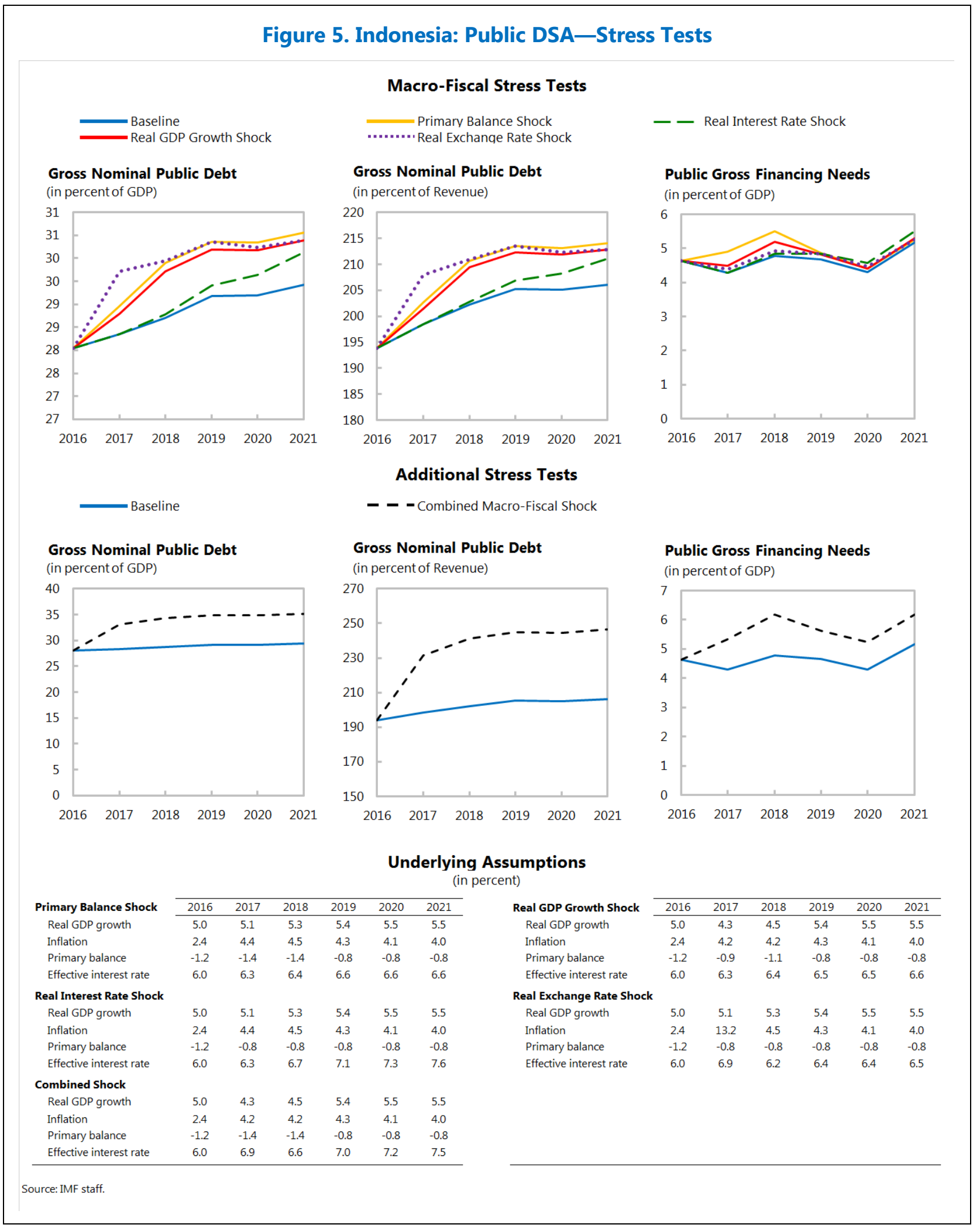




\section{INTERNATIONAL MONETARY FUND}

\section{INDONESIA}

STAFF REPORT FOR THE 2016 ARTICLE IV

December 27, 2016 CONSULTATION-INFORMATIONAL ANNEX

Prepared By Asia and Pacific Department

\section{CONTENTS}

FUND RELATIONS $\underline{\mathbf{2}}$

WORLD BANK-IMF COLLABORATION $\underline{4}$

RELATIONS WITH THE ASIAN DEVELOPMENT BANK $\underline{8}$

STATISTICAL ISSUES $\underline{10}$ 


\section{FUND RELATIONS}

(As of November 30, 2016)

Membership Status: Joined February 21, 1967; Article VIII

General Resources Account

\begin{tabular}{|l|r|r|}
\hline & SDR Millions & Percent of Quota \\
\hline Quota & $4,648.40$ & 100.00 \\
\hline Fund holdings of currency & $3,860.60$ & 83.05 \\
\hline Reserve tranche position in Fund & 787.82 & 16.95 \\
\hline
\end{tabular}

SDR Department

\begin{tabular}{|l|r|r|}
\hline & SDR Millions & Percent of Allocation \\
\hline Net cumulative allocation & $1,980.44$ & 100.00 \\
\hline Holdings & $1,118.56$ & 56.48 \\
\hline
\end{tabular}

Outstanding Purchases and Loans: None

Financial Arrangements

\begin{tabular}{|l|c|c|c|c|}
\hline Type & $\begin{array}{c}\text { Approval } \\
\text { Date }\end{array}$ & $\begin{array}{c}\text { Expiration } \\
\text { Date }\end{array}$ & $\begin{array}{c}\text { Amount } \\
\text { Approved } \\
\text { (SDR Millions) }\end{array}$ & $\begin{array}{c}\text { Amount } \\
\text { Drawn } \\
\text { (SDR Millions) }\end{array}$ \\
\hline EFF & $02 / 04 / 00$ & $12 / 31 / 03$ & $3,638.00$ & $3,638.00$ \\
\hline EFF & $08 / 25 / 98$ & $02 / 04 / 00$ & $5,383.10$ & $3,797.70$ \\
\hline Stand by & $11 / 05 / 97$ & $08 / 25 / 98$ & $8,338.24$ & $3,669.12$ \\
\hline
\end{tabular}

Projected Payments to Fund (SDR millions; based on existing use of resources and present holdings of SDRs):

\begin{tabular}{|l|r|r|r|r|r|}
\hline & \multicolumn{5}{|c|}{ Forthcoming } \\
\hline & $\mathbf{2 0 1 6}$ & $\mathbf{2 0 1 7}$ & $\mathbf{2 0 1 8}$ & $\mathbf{2 0 1 9}$ & $\mathbf{2 0 2 0}$ \\
\hline Principal & & & & & \\
\hline Charges/Interest & 2.01 & 2.05 & 2.05 & 2.05 & 2.05 \\
\hline Total & 2.01 & 2.05 & 2.05 & 2.05 & 2.05 \\
\hline
\end{tabular}

\section{Exchange Arrangements}

The rupiah has had a de jure free floating exchange arrangement since August 14, 1997, and the current de facto arrangement is floating. The market exchange rate was Rp 13,555 per U.S. dollar as of November 30, 2016. Indonesia has accepted the obligations of Article VIII, Sections 2, 3, and 4, and maintains an exchange system free of restrictions on payments and transfers for current international transactions. 


\section{Article IV Consultation}

The last Article IV consultation report (IMF Country Report No. 16/81) was discussed by the Executive Board on February 24, 2016.

\section{Resident Representative}

Mr. John Nelmes took over from Mr. Benedict Bingham as Senior Resident Representative since September 2016. 


\section{WORLD BANK-IMF COLLABORATION}

The working relationship between the IMF and the World Bank in Indonesia is very strong, with joint working programs in a number of areas and close coordination through frequent meetings between resident offices and headquarters missions, including during the Article IV consultation.

\section{Key Areas with Joint Programs}

\section{Budget Reforms}

- The reform agenda for budget and treasury remains a high priority for both institutions. Currently, the World Bank's support is being provided through the Government Financial Management and Revenue Administration Project (GFMRAP) program, trust funds, and development policy loans (DPLs), with elements in support of (a) efficient treasury operations, including accounting reforms, improved in-year budget disbursement, and regulatory reform;

(b) improved linkages between planning and budget preparation through the implementation of a medium-term expenditure framework, performance budgeting, and the enhancement of budget flexibility at the service delivery level; and (c) improved capacity for budget oversight through systems and organizational reform. Indonesia's Ministry of Finance launched SPAN in April 2015. SPAN, a financial management information system supported by GFMRAP, is designed to improve transparency, efficiency, and accountability of the government's financial transactions. An updated Public Expenditure review and further analysis in 2017 are informing the efficiency and effectiveness of government budgets. An ongoing Development Policy Loan (DPL) on fiscal reforms also supports reforms to enhance the allocative efficiency and effectiveness of public spending. The IMF has complemented this work through recent technical assistance (TA) on subsidy reform and social safety nets aimed at ensuring longer-run fiscal sustainability.

\section{Taxation Issues}

- Revenue (tax and nontax revenue) issues are a priority for the IMF and the World Bank, with broadening the revenue base and increasing revenues an important issue for both macro-fiscal stability and the investment climate. The Fund conducted a mission on tax policy and administration in September 2014 to identify key reform options in each of these areas. The Bank provides tax policy (including international tax) and administration support through trust funded TA to the Fiscal Policy Agency and DG Tax and an ongoing DPL on fiscal reforms. The Bank has also been providing analytical support on nontax revenue administration.

\section{Asset-Liability Management}

- The World Bank and IMF have been leading an effort to improve asset-liability management, including at the Treasury and Debt Management Office of the Ministry of Finance and at Bank Indonesia, with continued collaboration envisaged, as needed. 


\section{Crisis Preparedness}

- In recent years, the World Bank has focused on supporting the authorities in Indonesia to create a robust crisis prevention and management framework. Most recently, this support has included analysis of the financial sector stability framework through the 2010 FSAP and a series of crisis simulation exercises. Preparation is underway for the next FSAP. Between 2012 and 2015, the Bank's Program for Economic Resilience, Investment and Social Assistance in Indonesia (PERISAI) DPL, now disbursed and closed, has also supported the authorities in this area. The IMF has supported work in this area through past TA on reviewing the legal framework underpinning Indonesia's financial stability architecture and in its current surveillance dialogue with the authorities and exchange of views with the Bank.

\section{Financial Sector}

- The World Bank has focused on broad monitoring of the financial sector. Through its Financial Sector and Investment Climate Reform and Modernization DPL, the Bank supported the implementation of reforms aimed at maintaining stability, increasing diversification, and enhancing financial sector inclusion in Indonesia. The IMF has concentrated on the banking system, with emphasis on regulation and supervision, with a resident advisor placed at the Financial Services Agency (OJK) in January 2015. It has also embarked on TA in financial deepening, focused initially on money and foreign exchange market development and more recently on monetary operations and the transmission mechanism. In addition, the Fund has provided recent TA on the macro prudential policy framework and bank stress testing. A joint World Bank-IMF FSAP was completed in 2010 and some recommendations have been followed through by the authorities. The Bank is to provide TA to implement select FSAP recommendations concerning the nonbank financial sector.

\section{Statistics}

- The World Bank has a major program of capacity building with the statistics agency that was launched in 2011. The Statistical Capacity Building-Change and Reform for the Development of Statistics (STATCAP-CERDAS) program is designed to focus on improvements in key statistical series that should improve the ability to understand the Indonesian economy, executed through an institution-wide approach, which includes significant business, IT and HR/organizational reforms. The IMF has focused recent training and TA on government finance statistics, monetary and financial statistics, and sectoral balance sheets.

\section{Macroeconomics}

- The IMF continues to take the lead in macroeconomic areas, with the Article IV mission and staff visits, focusing on fiscal, monetary, and exchange rate policies; macro-financial linkages, financial sector reforms, and crisis management, as well as the external position and spillover effects. The Fund also updates the Debt Sustainability Analysis at the time of the Article IV consultation, with inputs from the World Bank and other development partners. The Bank has also taken on a larger role, including on macroeconomic monitoring, public policy dialogue, and capacity 
building, with ongoing coordination with the Fund. The Bank continues to assist the Ministry of Finance's Fiscal Policy Office to improve capacity for macroeconomic monitoring, forecasting, and evidence-based macroeconomic and fiscal policy analysis.

These threads of work are expected to be continued by both institutions, with periodic meetings aimed at keeping each other informed about ongoing work and joint areas of interest. Issues being addressed by the IMF include domestic and external vulnerabilities, exchange rate management, medium-term external and fiscal sustainability, and macrofinancial linkages and financial stability risks; and by the Bank the link between macrofiscal policy and real economic outcomes, including growth and poverty, resource-sector fiscal revenues, and longstanding problems in the implementation and effectiveness of government spending. 


\begin{tabular}{|c|c|c|c|}
\hline \multicolumn{4}{|c|}{ Indonesia: Joint Managerial Action Plan, 2015-16 } \\
\hline Title & Products & $\begin{array}{l}\text { Provisional } \\
\text { Timing of } \\
\text { Missions }\end{array}$ & $\begin{array}{c}\text { Expected Delivery Date } \\
\text { (Tentative) }\end{array}$ \\
\hline \multicolumn{4}{|c|}{ A. Mutual Information on Relevant Work Programs } \\
\hline $\begin{array}{l}\text { Bank work } \\
\text { program for } \\
\text { next } \\
12 \text { months }\end{array}$ & $\begin{array}{l}\text { Indonesia Economic Quarterly } \\
\text { World Bank follow-up work related to WB/IMF } \\
\text { Financial System Assessment Program missions } \\
\text { (October } 2009 \text { and February-March 2010) } \\
\text { Energy DPL } \\
\text { Fiscal reform DPL }\end{array}$ & & $\begin{array}{l}\text { Launched in April 2012; the } \\
\text { latest issue published in } \\
\text { December } 2015 \\
\text { Ongoing } \\
\text { Ongoing } \\
\text { Ongoing }\end{array}$ \\
\hline $\begin{array}{l}\text { IMF work } \\
\text { program for } \\
\text { next } \\
12 \text { months }\end{array}$ & $\begin{array}{l}\text { Macroeconomic surveillance } \\
2015 \text { Article IV consultation } \\
2016 \text { staff visit } \\
2016 \text { Article IV consultation } \\
\text { Technical assistance } \\
\text { Financial deepening and market development } \\
\text { Tax policy and revenue administration } \\
\text { Statistical policies } \\
\text { Consolidated supervision (resident advisor) }\end{array}$ & $\begin{array}{l}\text { December } 2015 \\
\text { August } 2016 \\
\text { November } 2016 \\
\text { Ongoing } \\
\text { Ongoing } \\
\text { Ongoing } \\
\text { Ongoing }\end{array}$ & $\begin{array}{l}\text { Board discussion took place in } \\
\text { February } 2016 \\
\text { Board discussion will take place } \\
\text { in January } 2017 \\
\text { Periodic visits }\end{array}$ \\
\hline \multicolumn{4}{|c|}{ B. Request for Work Program Inputs } \\
\hline $\begin{array}{l}\text { Fund request } \\
\text { to Bank }\end{array}$ & $\begin{array}{l}\text { Assessment of economic developments and } \\
\text { structural policies } \\
\text { Information sharing }\end{array}$ & & $\begin{array}{l}\text { Ongoing } \\
\text { Ongoing }\end{array}$ \\
\hline $\begin{array}{l}\text { Bank request } \\
\text { to Fund }\end{array}$ & $\begin{array}{l}\text { Assessment of macroeconomic developments } \\
\text { and policies } \\
\text { Information sharing }\end{array}$ & & $\begin{array}{l}\text { Ongoing } \\
\text { Ongoing }\end{array}$ \\
\hline \multicolumn{4}{|c|}{ C. Agreement on Joint Products and Missions } \\
\hline $\begin{array}{l}\text { Joint work } \\
\text { program }\end{array}$ & $\begin{array}{l}\text { Coordination of a follow-up FSAP starting } \\
\text { in } 2016\end{array}$ & $\begin{array}{l}\text { Mid-2016 } \\
\text { February } 2017\end{array}$ & $2016-2017$ \\
\hline
\end{tabular}




\section{RELATIONS WITH THE ASIAN DEVELOPMENT BANK}

(As of October 2016)

Asian Development Bank (ADB) loans to Indonesia have totaled US $\$ 31.5$ billion since $1969 .{ }^{1}$ The ADB approved a total of US $\$ 1.4$ billion in loans to Indonesia in 2015. The sectors with the largest shares in cumulative lending are public sector management (18.9 percent), energy (14.4 percent), agriculture and natural resources (14.1 percent), and finance (13.4 percent). ${ }^{2}$

Between 1969 and 2015, the ADB provided TA grants to Indonesia amounting to US $\$ 437$ million. The TA grants were financed from the ADB's TA Special Fund, the Japan Special Fund and other sources.

The ADB has completed a new Country Partnership Strategy (CPS) 2016-2019 for Indonesia, aligned with the government's medium-term development plan for 2015-2019. The CPS is closely attuned to the needs of Indonesia as a large middle-income country and guided by the government's commitment on development. The CPS will also maintain consistency with the priorities set out in ADB's Mid-Term Review of Strategy 2020.

ADB's new partnership with Indonesia will be working toward inclusive and environmentally sustainable growth through improved infrastructure services, better economic governance, and enhanced human resource development.

Table 1. Sovereign and Nonsovereign Loan Approvals and Disbursements to Indonesia (In millions of U.S. dollars)

\begin{tabular}{|l|r|r|r|r|r|r|r|r|}
\hline & \multicolumn{1}{|c|}{2008} & \multicolumn{1}{c|}{2009} & \multicolumn{1}{c|}{2010} & \multicolumn{1}{c}{2011} & 2012 & 2013 & 2014 & 2015 \\
\hline Loan approvals & $1,085.0$ & $2,184.2$ & 785.0 & 580.0 & $1,232.8$ & $1,013.9$ & 554.4 & $1,375.0$ \\
\hline Loan disbursements & 949.6 & 739.3 & $1,079.8$ & 631.9 & 862.5 & 588.1 & 543.7 & 1.401 .8 \\
\hline
\end{tabular}

Source: Indonesia Resident Mission, Republic of Indonesia.

\footnotetext{
${ }^{1}$ Through the last quarter of 2015.
}

2 See Table 2. 
Table 2. Cumulative Lending, Grant and Technical Assistance to Indonesia (As of December 2015)

\begin{tabular}{|lrrr|}
\hline \multicolumn{1}{c}{ Sector } & $\begin{array}{c}\text { Loans } \\
\text { (No.) }\end{array}$ & $\begin{array}{r}\text { Amount } \\
\text { (US\$ millions) }\end{array}$ & Percent 1/ \\
\hline Agriculture and natural resources & 273 & $4,299.40$ & 13.46 \\
Education & 80 & $2,455.75$ & 7.69 \\
Energy & 84 & $4,416.29$ & 16.88 \\
Finance & 68 & $4,111.43$ & 14.13 \\
Health and social protection & 45 & $1,104.76$ & 3.46 \\
Industry and trade & 39 & 660.58 & 2.07 \\
Public sector management & 108 & $5,800.46$ & 18.16 \\
Transport and information and communications technology & 89 & $3,701.00$ & 11.59 \\
Water supply and other municipal & 92 & $2,208.89$ & 6.92 \\
Infrastructure and services & & & $1,797.20$ \\
Multisector & 28 & & 5.87 \\
& & & \\
\hline Source: Asian Development Bank, Indonesia Fact Sheet 2015. & & & \\
1/ Total may not add up because of rounding. & & & \\
\hline
\end{tabular}




\section{STATISTICAL ISSUES}

\section{Assessment of Data Adequacy for Surveillance}

General: Indonesia's macroeconomic statistics are broadly adequate to conduct effective surveillance.

National accounts: Statistics Indonesia (BPS) disseminates annual and quarterly GDP (QGDP) by economic activity and expenditure components at current prices and in volume terms at 2010 prices regularly. In general, GDP estimates are based on the latest international methodologies following the System of National Accounts 2008. The QGDP estimates are based on a limited set of indirect indicators. Some sectors are influenced strongly by seasonality, with seasonally adjusted data prepared but not published. BPS has been leading the work on developing sectoral accounts and balance sheets jointly with Bank Indonesia (BI) with TA from STA. BPS and BI expect to finalize the annual nonfinancial accounts, financial flows, and stocks for the year 2010, and quarterly financial flows and stocks starting from Q1:2015 in 2017. A TA mission on Sectoral Accounts and Balance Sheets will be fielded in January 2017.

Price statistics: Price statistics are broadly adequate for surveillance. In October 2013, BPS released the new Producer Price Index (PPI) covering agriculture, mining and quarrying, and manufacturing with 2010 as the base period, and has published the PPI index quarterly. BPS has also expanded the mining sample to include oil and natural gas extraction, coal, and gold, and starting or completing work to further expand PPI coverage to include 15 service industries. There is a need to increase dissemination frequency and update the weights. Bank Indonesia and BPS have jointly begun work to expand the coverage of the residential property price index (RPPI) to include resales (the current RPPI includes only the sales of newly constructed units). It is planned that the new index will be released later in 2016.

Government finance statistics (GFS): The Ministry of Finance (MOF) is committed to keeping the requirements of fiscal statistics at the forefront of ongoing fiscal reforms, with better statistical monitoring one of the goals of the current efforts. The authorities are continuing their efforts to adopt the GFSM 2001/2014 standards, with assistance from STA as part of a regional GFS project. Significant progress has been made in these areas and, in 2013, Indonesia reported for the first time to STA general government data (including balance sheet data) covering the period 2008 onwards. Aggregated data on the budget of the central government are available with a one-month lag. Annual general government GFS are currently available 12 months after the end of the reference period and these data are published on the GFS website: http://www.gfs.djpbn.kemenkeu.go.id/en. The timeliness of the annual data will improve once all systems are in place.

The authorities have started to compile quarterly general government data in 2015. Quarterly general government GFS (operations statement) are available 6 months after the end of the reference quarter. The quarterly general government data are yet to be published on the GFS website because the authorities are planning to improve these data in terms of coverage of local governments and timeliness with the development of new regional financial information system.

In late 2015 , the authorities have started to develop methodology to compile quarterly general government data based on estimates of local government data.

The coverage and timeliness of public debt statistics are generally adequate. 
Monetary and financial statistics (MFS) and financial soundness indicators (FSIs): Good quality monetary statistics are compiled by BI on a timely basis. BI compiles and reports monetary data using the Standardized Report Forms (SRFs), from which an integrated database and alternative presentations of monetary statistics can be drawn to meet the needs of BI and the IMF. Additional challenges include timely revisions of published banking sector data after supervisory verification. With the support of a Fund TA mission in October 2014, BI expanded the coverage of the OFCs survey, which since January 2015 includes finance companies, insurance companies, pension funds, the state owned pawn shop (PT Pegadaian), and the Indonesian export financing institution (Eximbank); achieving almost full coverage of the subsector. OFC data are reported on a monthly basis. The mission also assisted BI in advancing the production of flow-based monetary statistics and quarterly financial accounts. BI compiles and reports to the Fund all (12) core and 12 encouraged financial soundness indicators (FSIs) for deposit takers, all (two) encouraged FSIs for OFCs, two encouraged FSIs for nonfinancial corporations, one encouraged FSI for households, two encouraged FSIs for market liquidity, and three encouraged FSIs for the real estate sector, which are published quarterly on the Fund's FSI website.

Balance of payments (BOP): Trade data have been improved in recent years. Import and export transactions of free trade zones and bonded warehouses are captured in goods data of BOP statistics.

For the capital and financial account, the methodological basis for the compilation of FDI data needs substantial improvement. Inflows are currently calculated based on loan disbursements to companies that have foreign equity using a fixed ratio to estimate equity inflows. Surveys conducted by BI to collect FDI data have improved the coverage of the directory of enterprises in recent years. Other areas that need improvement include the recording of trade credits and the asset data for portfolio investment and other investment transactions. The magnitude of the errors and omissions item in the BOP has been large at times and appears to be related to the under coverage of assets in the financial account. Financial transactions data are reconciled with changes in the International Investment Position (IIP), except data on direct investment.

Annual and quarterly IIP data are compiled and published, but the underlying data are weak in several areas, notably for FDI. External debt statistics have improved considerably with the introduction of an External Debt Information System (EDIS) in 2002 and the recent initiative to publish monthly indicators. Also, as a result of the ongoing reconciliation of data conducted by BI, the IIP and external debt data are fully consistent. However, improvements are still needed with respect to components of private corporate sector data, particularly in distinguishing between scheduled and actual debt service, in estimating the accumulation/reduction of private sector payments arrears, and in estimating reschedulings/debt reductions received by the private sector from external creditors.

\section{Data Standards and Quality}

Subscriber to the Special Data Dissemination Standard (SDDS) since September 1996, observing most of the SDDS requirements. Indonesia uses the SDDS flexibility options for the timeliness of the labor market categories (employment, unemployment, and wages/earnings) and general government operations.
Data Reports on the Observance of Standards and Codes (ROSC) completed in 2005. 


\section{Indonesia: Table of Common Indicators Required for Surveillance}

(As of November 21, 2016)

\begin{tabular}{|c|c|c|c|c|c|c|c|}
\hline & & & & & & Memorandu & m Items: \\
\hline & $\begin{array}{c}\text { Date of } \\
\text { Latest } \\
\text { Observation }\end{array}$ & $\begin{array}{l}\text { Date } \\
\text { Received }\end{array}$ & $\begin{array}{l}\text { Frequency } \\
\text { of } \\
\text { Data }^{1}\end{array}$ & $\begin{array}{l}\text { Frequency } \\
\text { of } \\
\text { Reporting }^{1}\end{array}$ & $\begin{array}{l}\text { Frequency of } \\
\text { Publication }^{1}\end{array}$ & $\begin{array}{l}\text { Data Quality- } \\
\text { Methodological } \\
\text { Soundness }{ }^{2}\end{array}$ & $\begin{array}{c}\text { Data } \\
\text { Quality- } \\
\text { Accuracy } \\
\text { and } \\
\text { Reliability }\end{array}$ \\
\hline Exchange rates & $11 / 21 / 16$ & $11 / 21 / 16$ & D & D & D & & \\
\hline $\begin{array}{l}\text { International reserve assets and } \\
\text { reserve liabilities of the monetary } \\
\text { authorities }{ }^{4}\end{array}$ & $11 / 16$ & $10 / 16$ & M & M & M & & \\
\hline Reserve/base money & $11 / 16$ & $9 / 16$ & W/M & W/M & $\mathrm{W} / \mathrm{M}$ & $\mathrm{O}, \mathrm{LO}, \mathrm{O}, \mathrm{O}$ & LO, O, O, LO, \\
\hline Broad money & $11 / 16$ & $9 / 16$ & M & M & M & & \\
\hline Central bank balance sheet & $11 / 16$ & $10 / 16$ & M & M & M & & \\
\hline $\begin{array}{l}\text { Consolidated balance sheet of the } \\
\text { banking system }\end{array}$ & $11 / 16$ & $9 / 16$ & M & M & M & & \\
\hline Interest rates ${ }^{5}$ & $11 / 21 / 16$ & $11 / 21 / 16$ & D & D & D & & \\
\hline Consumer price index & $11 / 16$ & $10 / 16$ & M & M & M & & \\
\hline $\begin{array}{l}\text { Revenue, expenditure, balance } \\
\text { and composition of financing } \\
\text { central government }\end{array}$ & $11 / 16$ & $9 / 16$ & M & M & Mid-year & $\begin{array}{l}\text { LNO, LNO, LO, } \\
\text { LNO }\end{array}$ & $\begin{array}{l}\text { LNO, LO, LO, } \\
\text { LO, LNO }\end{array}$ \\
\hline $\begin{array}{l}\text { Stocks of central government and } \\
\text { central government-guaranteed } \\
\text { debt }\end{array}$ & $11 / 16$ & $9 / 16$ & Q & Q & Q & & \\
\hline External current account balance & $11 / 16$ & $9 / 16$ & Q & Q & Q & LO, LO, LO, LO & LO, O, LO, O, \\
\hline $\begin{array}{l}\text { Exports and imports of goods and } \\
\text { services }\end{array}$ & $11 / 16$ & $10 / 16$ & M & M & M & & \\
\hline GDP/GNP & $11 / 16$ & $9 / 16$ & Q & Q & Q & LO, LO, O, LO & $\begin{array}{l}\text { LO, LO, LO, } \\
\text { LO, LNO }\end{array}$ \\
\hline Gross external debt ${ }^{7}$ & $11 / 16$ & $9 / 16$ & Q & Q & $\mathrm{Q}$ & & \\
\hline International investment position ${ }^{8}$ & $11 / 16$ & $6 / 16$ & Q & $\mathrm{Q}$ & Q & & \\
\hline $\begin{array}{l}1 \text { Daily (D); Weekly (W); Monthly ( } \\
2 \text { Reflects the assessment provided } \\
\text { March 28-April 11, 2005), for the da } \\
\text { concerning concepts and definition } \\
\text { largely not observed (LNO); not obs } \\
3 \text { Including currency and maturity } ~ \\
\text { data, statistical techniques, assessm } \\
4 \text { Any reserve assets that are pledg } \\
\text { liabilities linked to a foreign currend } \\
\text { foreign currency, including those lir } \\
5 \text { Both market based and officially } \\
6 \text { Foreign, domestic bank, and dom } \\
7 \text { Including currency and maturity } ~ \\
8 \text { Includes external gross financial a }\end{array}$ & $\begin{array}{l}\text {; Quarterly (Q } \\
\text { in the data RO } \\
\text { taset correspo } \\
\text {; scope, classi } \\
\text { erved (NO); an } \\
\text { omposition, ex } \\
\text { ent and valida } \\
\text { d or otherwise } \\
\text { y but settled b } \\
\text { ked to a foreic } \\
\text { etermined, inc } \\
\text { estic nonbank } \\
\text { smposition. } \\
\text { sets and liabil }\end{array}$ & $\begin{array}{l}\text { Annually (A) } \\
\text { c published } \\
\text { ding to the } \\
\text { ation/sector } \\
\text { not availabl } \\
\text { pt referring } \\
\text { n of interm } \\
\text { ncumbered } \\
\text { other mean } \\
\text { currency bu } \\
\text { ding discou } \\
\text { hancing. } \\
\text { positions v }\end{array}$ & $\begin{array}{l}\text { A: Not Avail } \\
\text { July } 20,200 \\
\text { iable in each } \\
\text { ation, and ba } \\
\text { NA). } \\
\text { internation } \\
\text { iate data anc } \\
\text { ould be spe } \\
\text { s well as the } \\
\text { eettled by ot } \\
\text { rates, mone } \\
\text { à-vis nonres }\end{array}$ & $\begin{array}{l}\text { ble. } \\
\text { (based on th } \\
\text { ow. The asses } \\
\text { s for recordir } \\
\text { standards co } \\
\text { statistical out } \\
\text { fied separate } \\
\text { lotional value } \\
\text { er means. } \\
\text { market rates, } \\
\text { lents. }\end{array}$ & $\begin{array}{l}\text { findings of the } \\
\text { ment indicates } \\
\text { are fully obser } \\
\text { cerning source } \\
\text { uts, and revisio } \\
\text { Also, data sho } \\
\text { of financial der } \\
\text { ates on treasur }\end{array}$ & $\begin{array}{l}\text { mission that took } \\
\text { whether internatio } \\
\text { ved }(0) \text {; largely ob } \\
\text { data, assessment } \\
\text { studies. } \\
\text { uld comprise shor } \\
\text { ivatives to pay and } \\
\text { bills, notes and b }\end{array}$ & $\begin{array}{l}\text { place during } \\
\text { nal standards } \\
\text { served (LO); } \\
\text { f source } \\
\text { to receive } \\
\text { onds. }\end{array}$ \\
\hline
\end{tabular}




\section{Statement by IMF Staff Representative on Indonesia \\ January 25, 2017}

The following information, which does not alter the thrust of the staff appraisal, has become available following the issuance of the staff report.

\section{The latest data released include:}

- Headline inflation fell to 3.0 percent $(y / y)$ in December 2016 on lower food prices inflation, while core inflation remained stable at 3.1 percent $(y / y)$.

- Based on preliminary data, the central government deficit for 2016 as a whole was 2.5 percent of GDP, with somewhat lower government revenue (12.4 percent of GDP) and expenditure (14.9 percent of GDP) than those projected in the staff report. Collections from the tax amnesty for 2016 as a whole were Rp 107 trillion (0.9 percent of GDP).

- International reserves rose to US\$116.4 billion at end-December 2016, following a US\$3.5 billion international sovereign bond issuance in December.

2. Financial markets have stabilized. Since mid-December, the rupiah has appreciated by around 0.1 percent vis-à-vis the U.S. dollar, the 10-year government bond yields has fallen by about 25 bps, and equities rose by 1.8 percent, with stable capital flows. Market movements appear broadly in line with those of regional EM peers.
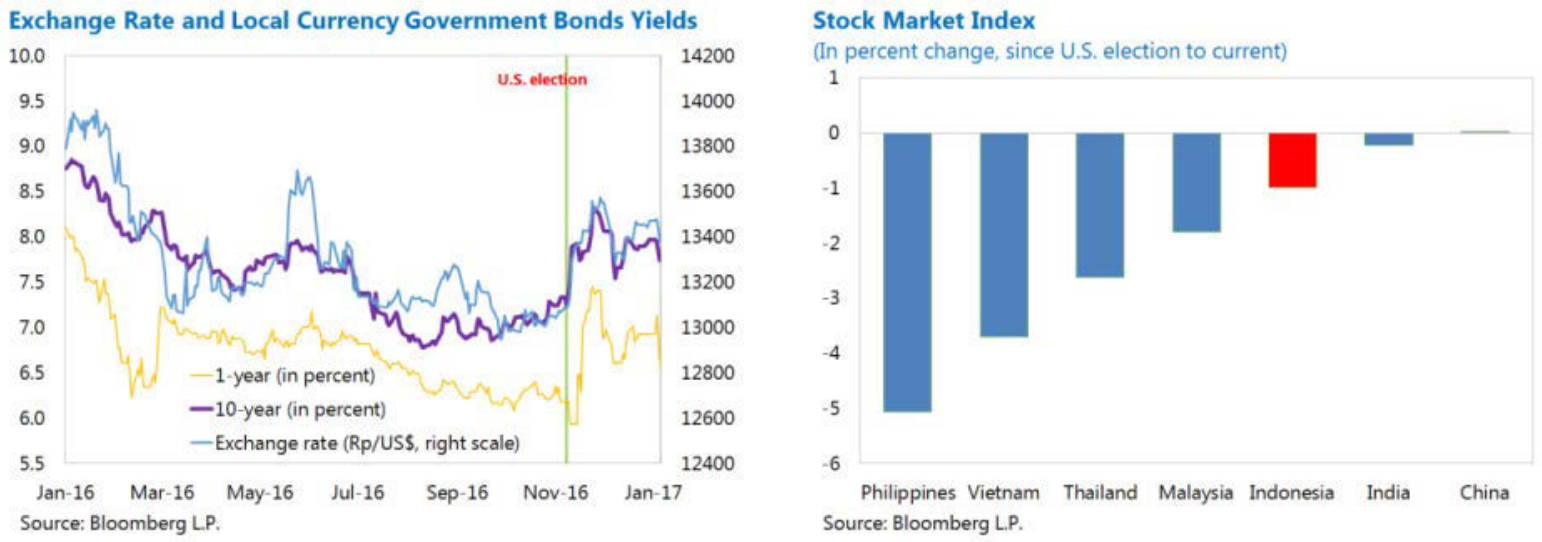

\section{On December 21, Fitch upgraded Indonesia's sovereign rating's outlook from} "stable" to "positive" and affirmed the rating at BBB- (Investment Grade). The cited factors for the upgrade were: (i) the track record of macroeconomic stability; (ii) effective monetary and exchange rate policy in response to market turmoil; and (iii) a strong structural reform drive since 2015. 


\section{Statement by Marzunisham Omar, Executive Director for Indonesia and Arief Machmud, Senior Advisor to Executive Director January 25, 2017}

On behalf of the Indonesian authorities, we would like to express our appreciation to the IMF mission team for the candid discussions and policy dialogue during the 2016 Article IV consultation.

The authorities are in broad agreement with the focus of this year's consultation which is to strengthen the medium-term policy framework to support more inclusive growth, while preserving macroeconomic stability in a prolonged uncertain and volatile external environment. The authorities are encouraged by staff's acknowledgement of Indonesia's robust macroeconomic performance, proper policy management and ongoing structural reforms.

Nevertheless, the authorities view that the policy recommendations and risk analyses need to consistently take into account the progress made thus far by the authorities as well as Indonesia's solid and sound macroeconomic and financial conditions. Notable examples are in staff's assessment of the external sector development and financial and corporate sector issues. As an illustration, adding the word 'continue' to the last sentence of the key issues section in the staff report ("....the policy strategy should continue to include actions to boost the economy's resilience, .....") would provide a more accurate picture of the Indonesian economy as well as acknowledge the efforts of the authorities.

We view that against the risks mentioned, a qualifying opinion from staff to where Indonesia currently stands and its ability to weather the risks is very important. The absence of this qualifying opinion would result in a rather pessimistic assessment and draw unnecessary attention which is inconsistent with Indonesia's economic resilience and positive prospects. As Article IV is an important reference for the global community at large, we view it is imperative for the analysis to put more weight on coherence rather than completeness. This is important for Indonesia as well as for other emerging market economies as an overemphasis of risk aspects could affect the confidence of investors and financial market participants which is unfair to the country. In this respect, we wish to highlight the following areas.

\section{Recent Economic Developments and Outlook}

Indonesian economic policies are guided by a sound macropolicy direction which enables the economy to withstand volatile external conditions. Notwithstanding the complexity of the policy challenges emanating from the external headwinds and the on-going structural reforms in the domestic economy, the authorities have employed a so called "Bauran Kebijakan" or "the policy mix strategy". This policy mix strategy allows the authorities to determine a harmonious combination among monetary, fiscal and structural reform policies to ensure a more sustainable and inclusive economic growth. For instance, during the episode of taper tantrum, the 
macroeconomic strategy placed emphasis on maintaining stability over growth, whereby monetary policy was aimed at preserving stability while fiscal policy was directed at nurturing growth. Following a clearer direction in the US monetary policy normalization, the authorities shifted the strategy by using monetary policy primarily to support growth while pursuing fiscal consolidation to retain credibility. In the current complex situation, the macroeconomic strategy places greater weight on stability, while using structural reforms to strengthen growth. Throughout these periods, the policy combination is not only accompanied by deeper and stronger structural reforms but also a more flexible exchange rate regime, ample reserve level, calibrated macro-prudential policy and better communication strategy.

\section{The above strategies have resulted in the Indonesian economy performing well among} peers (recorded the third highest growth among G20 countries). The economy grew by 5.02 percent in the third quarter of 2016, bringing the estimated economic growth to 5 percent for the whole year. Inflation, at 3.02 percent in 2016, was at the lower range of the inflation target of $4 \pm 1$ percent. Fiscal deficit stood at 2.46 percent of GDP, while public debt remained low and manageable at 27.7 percent of GDP at the end of 2016, with well diversified currency composition (almost 60 percent in Rupiah-denominated debt) and debt maturity (weighted average of 9 years). The balance of payments recorded a larger surplus in the third quarter of 2016, supported by a narrower current account deficit and a larger capital and financial account surplus. The 2016 current account deficit is expected to be below 2 percent of GDP. International reserves remained sufficient at USD116.4 billion as of December 2016, equivalent to 8.4 months of imports and official debt repayment.

Consistency in maintaining macroeconomic stability while optimizing economic growth has safeguarded the economy's resilience and is recognized by international community. In December 2016, Fitch revised Indonesia's outlook to Positive and affirmed the Investment Grade. Correspondingly, the implementation of structural reforms has contributed to the significant improvement in Indonesia's ranking in the World Bank's Doing Business Index.

Indonesia's economic outlook is expected to further improve. The economy is projected to grow between 5.0-5.4 percent in 2017, supported by solid domestic demand and a recovery in exports, along with improvement in prices of Indonesia's export commodities. The government is expected to record a prudent fiscal deficit in 2017 coupled with a more realistic tax revenue target and better subsidy scheme. The 2017 budget will be primarily allocated to productive spending to support the growth momentum and improve infrastructure and basic services, including education, health and social welfare. Meanwhile, the current account deficit is expected to remain below 3 percent of GDP. The authorities will carefully monitor the impact of the plan to lower subsidy on some tariffs, such as electricity, on inflation, and will ensure that inflation expectations are firmly anchored. In addition, financial stability and corporate sector conditions are also expected to further improve in line with a better economic outlook. 


\section{External Sector Development}

The authorities are fully cognizant of the importance of the external sector and remain vigilant in maintaining and strengthening external resiliency. The authorities wish to highlight staff's assessment that Indonesia's external position is broadly consistent with mediumterm fundamentals and desirable policy settings. Further, staff also assessed that reserves are sufficient and that in the event of severe external pressure, exchange rate flexibility would help contain risks. While staff has rightly stressed that global uncertainty can have downside risk to the economy, the authorities wonder what is staff's final assessment of the resiliency of the Indonesian economy. Further, we would like to point out that the external risks mentioned are a global phenomenon not unique to Indonesia. Against this backdrop, the authorities would like to underline their confidence in weathering future external shocks, namely due to 3 factors:

(i) sound macroeconomic discipline; (ii) intensive monitoring of debt characteristics and compositions; and (iii) sound prudential policy to mitigate risks.

On sound macroeconomic discipline, the authorities focused on three major areas, namely a sustainable current account deficit (CAD), more flexible exchange rate and sufficient level of reserves. Indonesia's CAD has been on a declining trend and is consistent with mediumterm economic fundamentals. Over the years, the CAD has declined from 3.19 percent of GDP in 2013 to 2.06 percent of GDP in 2015. By the end of 2016, the CAD is projected to be below 2 percent of GDP. The authorities are committed to further safeguard the CAD within its medium-term sustainable level and to improve competitiveness and promote exports which would in turn further improve the CAD. On the exchange rate, Indonesia has implemented a more flexible exchange rate regime in line with its fundamental value. Exchange rate flexibility has helped increase the resilience of the external sector as reflected in improvements in the CAD. Meanwhile, international reserves are sufficient at USD116.4 billion as of December 2016, equivalent to 8.4 months of imports and official debt repayment. The reserves are further supported by the availability of a second line of defense from bilateral, regional and global financial arrangements which provide further buffers against external shocks.

The authorities will continue to monitor debt characteristics and compositions. Currently, Indonesia has a healthy International Investment Position structure, where net external liabilities are mostly long-term (FDI and long term loans) that will provide positive trickle-down effects on long-term economic activities and growth. Indonesia's long-term foreign borrowing amounts to 87.5 percent of total foreign borrowings with a balanced share between public and private debt. Short-term debt of private non-bank corporations amounts to only 5 percent of total foreign debt. Further, non-resident holders of Indonesian government bond are also dominated by long-term investors, including central banks.

In addition to implementing a strong policy framework, the authorities will continue to adopt necessary prudential regulations to maintain and strengthen external resiliency. To ensure prudent external debt management, the authorities have since end-2014 implemented prudential 
regulations to manage external debt of non-bank corporations, where non-bank corporations must meet minimum hedging and liquidity ratios as well as minimum credit rating requirement. This is in addition to the 3 percent fiscal deficit ceiling introduced by the State Law, a special committee to administer and approve the SOEs' related loans, and existing banking prudential regulations on loan and foreign exchange exposures.

\section{Financial and Corporate Sector Issues}

The authorities wish to highlight that the Indonesian financial and corporate sectors remain resilient and well placed to weather the current uncertain global conditions. As noted by staff, the banking system is well capitalized and profitable, with ample liquidity. The capital adequacy ratio stood at 23 percent at end-November 2016, well above the international standard. Meanwhile, ample liquidity is reflected in the low level of volatility of interbank market rate and the ratio of liquid assets to third party fund, which stood at 20.5 percent at endNovember 2016. Latest data have also signaled that NPLs' growth is reaching its peak in addition to improved corporate performance, especially in the commodity-related sector. Taking into account the positive outlook of the Indonesian economy and the rising commodity prices, risks emanating from the banking and corporate sectors are expected to moderate in the future. In sum, the authorities would like to underline a very important conclusion of the risk assessment on the banking and corporate sectors, namely that none of the identified risks triggers systemic concerns in the financial system, despite the said "pockets of vulnerability" in those areas.

To ensure that no vulnerability in the banking and corporate sectors persist, the authorities regularly monitor and conduct stress tests in compliance with international best practices. The results again confirmed that there is no systemic risk. As an example, the result of the authorities' stress test on liquidity shock showed that only 1 (one) small-sized banks (out of 118 banks) encountered a liquidity problem due to its reliance on short-term deposits. Nevertheless, the authorities assessed that the problem to be temporary and not a structural issue. Sufficient access to liquidity both from money market and the central bank is also available to the bank.

The same strong conclusion on the absence of systemic risk also hold true for the corporate sector. The authorities believe that corporate vulnerability will also decline in line with improvements in corporate performance as reflected in increasing profitability (data up to September 2016). This is further bolstered by improved efficiency including a tendency among corporations to reduce debts. In addition, the authorities would also like to refer to the analysis from related working paper ${ }^{1}$ draft by staff which states that risks in the Indonesian corporate sector are manageable and that the authorities have been proactive in monitoring corporate

\footnotetext{
${ }^{1}$ Chan-Lau, J. A., Miao, W., Miyajima, K., Shin, J, 2016, “Corporate Vulnerabilities in Indonesia: A Bottom-Up Default Analysis." IMF Working Paper (draft) WP/16/XX, pp.4.
} 
vulnerabilities. The above reference simply reinstated that there are no systemic risks stemming from the corporate sector.

In this regard, the authorities would like to convey the need to have a coherent assessment on the banking and corporate sectors to understand the depth of the problem and the ability of the authorities to handle the issues. Emphasizing the analysis on the risks would overshadow the progress made by the authorities in strengthening the resilience of the financial and corporate sectors and to address pockets of vulnerabilities.

\section{Fiscal Policy and Reforms}

On the fiscal front, the authorities appreciate staff recognition that the fiscal strategy is appropriate. The government has embarked on a gradual fiscal consolidation while protecting infrastructure priority spending. The tax amnesty program launched by the government has been successful in collecting significant tax payments and repatriated funds as well as expanding the revenue base.

Going forward, the authorities are committed to implement a growth-friendly fiscal strategy and concurred with staff's assessment that revenue mobilization will be challenging. Nevertheless, the authorities' commitment to achieving revenue targets remain unwavering. This effort will be supported by several factors, namely: (i) a new larger tax base as a result of information obtained through tax amnesty; (ii) potential for further revenue-raising reforms with the creation of a tax reform team in January 2017. The team will also help improve the organization and clarity of the tax reforms roadmap, which will improve credibility of the tax revenue target; (iii) plan to improve the information system to capitalize on the readily available information from tax amnesty; (iv) efforts to address complications in tax regulations as well as to implement tax policy and administration reforms by way of amendments to the VAT law and income tax law are also underway; (v) electronic invoicing. With the above progress and strategies, it is also worth noting that tax revenues will also move in line with the tax buoyancy rate. The authorities have also continued to work closely with the IMF through Technical Assistance to further improve the fiscal position.

\section{Structural Reforms}

The authorities have embarked on a series of structural reforms to improve the economy's competitiveness and the business climate. Focus areas of the reform are on improving the ease of doing business, providing good infrastructure, diversifying sources of growth (including developing the tourism sector and more value added export products), improving purchasing power and deepening the financial market. As staff noted, there are signs of early successes, as shown in the improvement of Indonesia's ranking in the Doing Business Index, which in 2016 moved up 15 positions to 91 . The deep and intensive reforms are aimed at supporting the National Strategic Development Plan (NSDP) 2014-2019 which is led directly by the President. 
The NDSP comprises of three arrows, namely human development, priority sector development and equitable development.

One important landmark in improving the investment climate is the establishment of OneStop Service (OSS) for investment under the Investment Coordinating Board Agency (BKPM), in January 2015. The objective of the OSS center is to accelerate and simplify licensing procedures for investment projects by placing the licensing processes for all businesses (except those in the banking and energy sectors) that were handled by 22 ministries and government agencies under one roof. The business climate has been further improved by the introduction of the 3-hour investment licensing service in January 2016 and the 10th Policy Package on Negative Investment List in February 2016. As many as 130 companies with investment value of IDR291 trillion have benefited from the OSS service up to October 2016. Meanwhile, up to June 2016, 527 companies have applied to invest with total planned investment of USD12.9 billion as a result of the revised Negative Investment List.

Debottlenecking effort was also done to accelerate the implementation of priority infrastructure projects. Recognizing the need to improve infrastructure, the authorities have established a body under the Economic Coordinating Minister as a Project Management Office (KPPIP) to administer 30 priority infrastructure projects, ranging from electricity, energy, seaport, airport and toll roads. One notable progress of this body is the revision of the Law on Land Acquisition for Public Interest which sets a maximum time to complete the land acquisition process, the biggest hurdle in undertaking infrastructure projects. To date, many projects, such as the Trans Sumatra Toll Road Project and Java North Line Double Track Rail Project, have benefited from the revision of this regulation.

\section{Conclusion}

The Indonesian economy is progressing well with well-preserved macroeconomic and financial stability. The authorities have proven their resolute commitment and are well prepared to tackle prolonged global uncertainty with appropriate policies. The authorities believe that combining policy mix with appropriate structural reforms provides optimal result for an emerging market economy such as Indonesia. To that extent, the authorities will continue its unwavering commitment to maintain macroeconomic stability and broad-based structural reforms. We believe that this commitment is a major factor in shaping the economy's agility in weathering shifts in the external environment and has been well tested in several episodes of global financial turbulence as well as during the period of commodity down-cycle. 